\title{
A revision of the genus Wahlenbergia (Campanulaceae) in Australia
}

\author{
Peter J. Smith
}

\begin{abstract}
Smith, Peter J. (44 Hawkins Parade, Blaxland, NSW, Australia 2774) 1992. A revision of the genus Wahlenbergia (Campanulaceae) in Australia. Telopea 5(1): 91-175. The Australian species of Wahlenbergia are examined from morphological and cytological evidence, and their relationships are discussed. Twenty-six species are recognised, including one introduced species. The following species are described as new: W. glabra, W. islensis, W. planiflora, W. scopulicola and W. victoriensis. Two subspecies are recognised in each of two species, with $\mathbf{W}$. planiflora subsp. longipila and $W$. stricta subsp. alterna being described as new. The native Australian species have a basic chromosome number of $x=9$. Polyploidy is common, with at least 11 taxa having two or more chromosome races (diploid, tetraploid, hexaploid or octoploid). It appears that speciation has occurred mainly at the diploid level, followed by extensive development of polyploid races within species and then another, lesser phase of speciation at the polyploid level. The native species are placed into four informal groups that reflect their supposed evolutionary relationships. The groups differ in growth-form, extent of polyploidy, habitat preferences and distribution patterns. Two groups have representatives elsewhere in Australasia and southern Asia. The affinities of all groups appear to be with African species of the W. undulata type, which also have a basic chromosome number of $x=9$.
\end{abstract}

\section{Introduction}

Wahlenbergia is a large genus of the family Campanulaceae, comprising some 200 species. Although some species occur in the northern hemisphere, the great majority of species are confined to the southern hemisphere. It forms a broad geographic and taxonomic complement to the mainly northern hemisphere genus, Campanula. The greatest diversity of species occurs in Africa, with lower numbers in South America, Asia and Australasia.

The name Wahlenbergia was first introduced by Schrader (1814). However, as pointed out by van Steenis (1960), Schrader's name is a nomen nudum and the first validly published description was by Roth (1821). An earlier validly published name for the genus is Cervicina (Delile 1813), which has been made a nomen rejiciendum in favour of Wahlenbergia (I.C.B.N. 1988: 275).

Tuyn (1960) reduced the genera Lightfootia and Cephalostigma to Wahlenbergia, an approach also followed by Thulin (1975). Lightfootia L'Héritier (1789) is an older name than Wahlenbergia, but is a later homonym of Lightfootia Swartz (1788). Neither Lightfootia nor Cephalostigma is represented in Australia. Black (1934) described Cephalostigma fluminale from South Australia, but this species has since been transferred to Wahlenbergia sens. strict. (Eichler 1963).

The first major treatment of Wahlenbergia was by de Candolle $(1830,1839)$, who considered all species known at the time. There have been no subsequent worldwide treatments. Von Brehmer $(1915 a, b)$ provided a detailed revision of the genus for Africa. Thulin $(1975,1987)$ provided a detailed revision for tropical Africa and Madagascar.

The first Australian treatment was by Robert Brown (1810), who recognised three species, one of which was divided into four varieties. These were described under a 
new section (Campanopsis) of Campanula, but have since been transferred to Wahlenbergia. Although several additional species had been described by the 1860 s, Bentham (1869) recognised only two, reducing all except $W$. saxicola to $W$. gracilis.

N.E. Brown (1913), in a partial review of Australian and New Zealand Wahlenbergia, recognised five species in Australia, two of which were divided into two varieties each. Black (1934) recognised five species in South Australia, including one described under Cephalostigma.

Lothian $(1947 a, b, c)$ recognised 14 native and one introduced species in Australia, including Lord Howe Island. He stated, however, that this was an incomplete list, especially for Queensland and Western Australia. He later described two additional alpine species (Lothian 1956).

Tuyn (1960), in his treatment of Malesian Wahlenbergia, reduced many of the species recognised by Lothian to synonymy with the Japanese species, W. marginata (Thunb.) A. DC., which was considered to have a wide distribution from Asia to Australia and New Zealand. This treatment has not been followed by any subsequent authors in Australia, although Webb et al. (1988: 457) have recently used the name in New Zealand.

Carolin (1964) provided taxonomic and nomenclatural notes on seven Australian species, two of which were described as new.

The present study involved examination of herbarium specimens together with field, glasshouse and cytological investigations. Altogether, some 5500 specimens have been examined and annotated, comprising collections from the following Australian herbaria: AD, ADW, BRI, CANB, CBG, DNA, HO, MEL, NSW, NT, PERTH and SYD. Type material held at European herbaria was only examined from photographs, but these specimens had been examined previously by R. Carolin. Twenty-two taxa were studied in the field, and 15 of these were grown in a glasshouse. Chromosome counts were obtained for the same 22 taxa, with up to 30 counts per taxon.

The major part of the study formed the basis of a Ph.D. thesis (Smith 1976). Five new species were described in an account of Wahlenbergia in South Australia (Smith 1986). Another new species was described (Smith 1989) for an account of the genus in the Kimberley Region of Western Australia (Wheeler \& Smith, in press). An account of the genus in New South Wales has also been prepared (Smith, in press).

\section{Morphology}

\section{Habit}

Although shrubby Wahlenbergia species occur elsewhere in the world, especially in South Africa and on islands such as Juan Fernandez and Ascension, the species in Australia are all perennial or annual herbs. Four growth-forms may be distinguished (Figure 1):

I. Densely tufted perennials with much-branched stems and short inflorescences, typically with only solitary flowers. This growth-form is found in three species, all of which grow in rock crevices: W. glabra, W. islensis and W. scopulicola.

II. Rhizomatous perennials with aerial stems and inflorescences that are unbranched or only sparingly branched. This growth-form is typical of the alpine and subalpine species, W. ceracea, W. densifolia, W. gloriosa and W. saxicola, but also occurs in two non-alpine species, W. gymnoclada and W. insulae-howei. W. insulae-howei, which typ- 
ically grows in rock crevices, often has a more tufted habit than the other species, but develops rhizomes in suitable conditions.

III. Tufted perennials with few to many stems and with branched inflorescences covering the upper half or more of the plant. This is the most common growth-form, typical of the majority of the more widespread species (see Table 2 for a list of species with this growth-form). The lateral roots of these species may give rise to other tufted, taprooted plants away from the original plant. This was confirmed in the field or glasshouse in W. communis, W. fluminalis, W. littoricola, W. luteola, W. planiflora and W. queenslandica, and is probably a general characteristic.
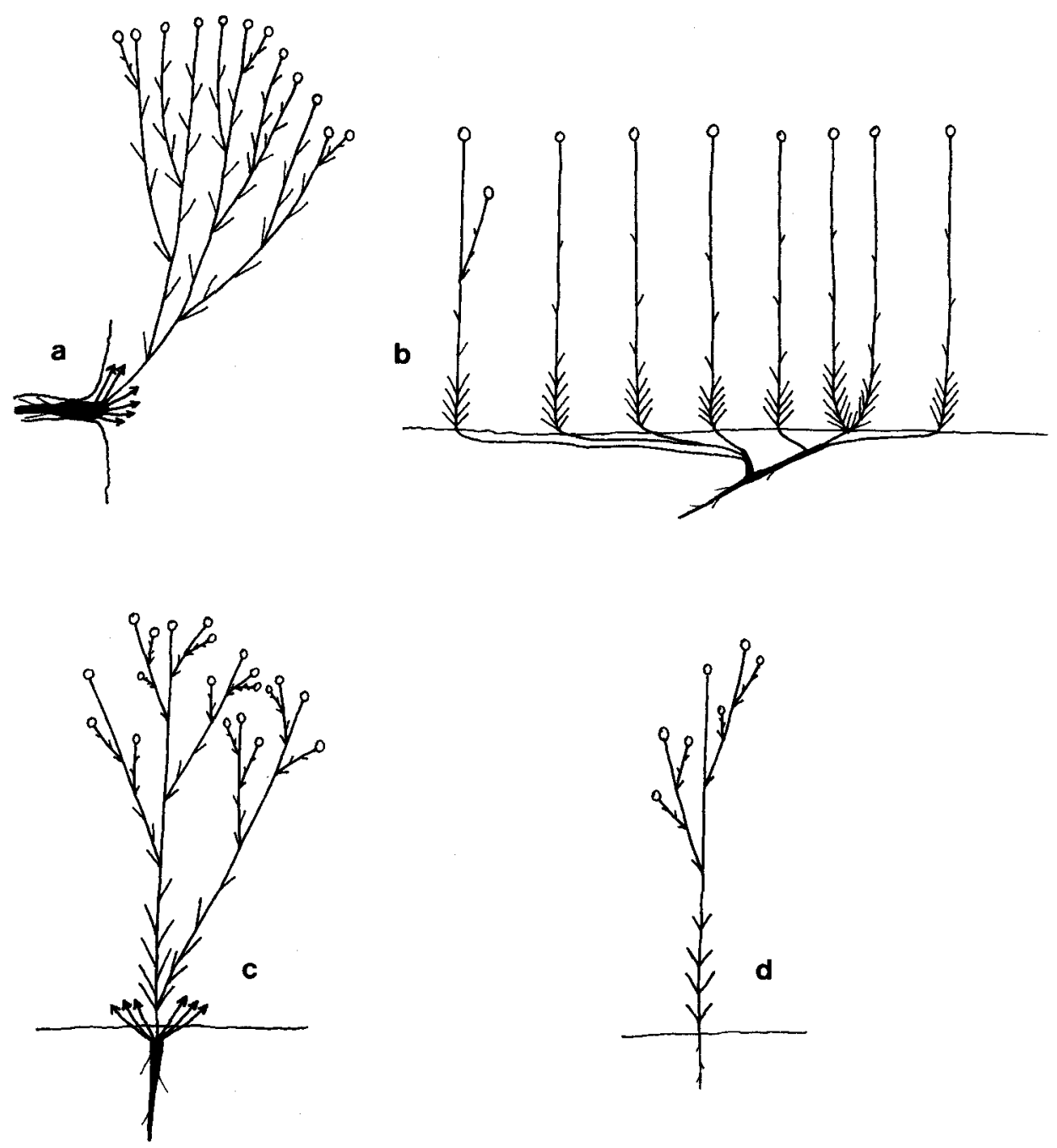

Figure 1. Growth-forms of Australian Wahlenbergia species. a, growth-form I, tufted perennial with \pm solitary flowers ( $W$. islensis); $\mathbf{b}$, growth-form II, rhizomatous perennial with \pm solitary flowers (W. gymnoclada); c, growth-form III, tufted perennial with branched inflorescence $(W$. communis); d, growth-form IV, annual with branched inflorescence (W. gracilenta). 
IV. Annuals with only one or a few stems and with branched inflorescences. The species that are consistently annual are W. caryophylloides, W. gracilenta, W. preissii, $W$. victoriensis and the introduced $W$. capensis. Young plants of normally perennial species are similar in appearance to annuals, and may not survive to a second year if conditions are unfavourable. However, only $W$. tumidifructa appears to have both a consistently annual form and a perennial form.

\section{Leaves}

The leaves may be alternate throughout, opposite on the lower stem becoming alternate above, or irregularly opposite and alternate. No species has leaves which are consistently opposite throughout. Only W. saxicola (regularly), W. insulae-howei (frequently) and $W$. gloriosa (occasionally) have leaves confined to basal rosettes, whereas this is the typical form of rhizomatous Wahlenbergia species in New Zealand.
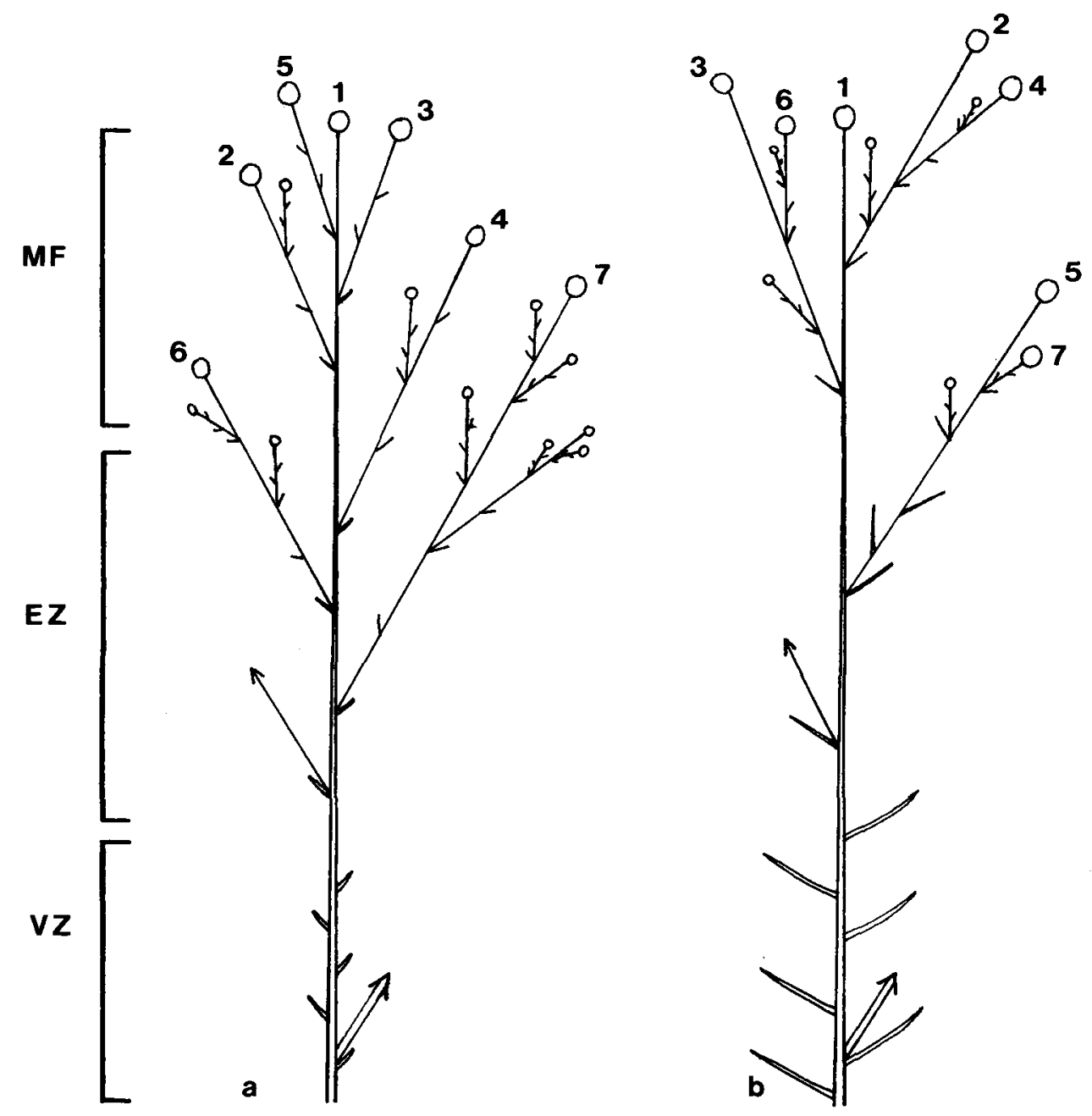

Figure 2. Inflorescences of African and Australian Wahlenbergia species. a, W. virgata, typical of African species (Thulin 1975, Fig. 2); b, W. communis, typical of Australian species. $M F=$ main florescence; $\mathrm{EZ}$ = enrichment zone; $\mathrm{VZ}$ = vegetative zone. Figures indicate order of flowering. 
The leaves are variable in size and shape along the stem, becoming smaller and more widely spaced on the upper stem, and typically changing in shape from broadest distally to broadest proximally. Considerable leaf variation is also induced by environmental conditions, with plants growing in sheltered sites tending to have larger, broader, thinner, flatter, more persistent leaves than plants growing in exposed sites.

Despite this variability, leaf shape and, to a lesser extent, size are often useful diagnostic characters. For example, the long, linear leaves of $W$. gymnoclada and the short, narrowly oblong leaves of $W$. densifolia readily distinguish these species from others of the same growth-form.

The leaves are sessile in all species except $W$. scopulicola, most leaves of which are distinctly petiolate.

\section{Indumentum}

The species vary from entirely glabrous (W. glabra and W. islensis) to extensively and consistently hirsute (W. capensis and W. scopulicola). However, the extent and density of the indumentum are often highly variable between and within local populations.

The indumentum terms used in this account are: 'hirsute' for the typical condition of longish, moderately stiff, white, simple hairs; 'pubescent' for the much shorter but otherwise similar indumentum of W. densifolia; and 'puberulous' for the very short, soft, white, simple hairs found inside the base of the corolla-tube in most species.

\section{Inflorescence}

Thulin (1975: 19-25) has discussed the inflorescence in African Wahlenbergia in relation to the concepts and terminology of Troll $(1964,1969)$ and Carolin (1967). He concluded that in the basic type, as illustrated by W. virgata Engl. (Figure 2), the main florescence consists not only of the terminal flower (as maintained by Troll 1964: 183), but also the three flowering branches immediately below, each of which has two bracteoles (prophylls) and may develop into a cyme. Flowering branches below the main florescence have 3-5 'bracteole-like leaves' (2 prophylls and 1-3 later phyllomes) and are similar in construction to the main florescence. These represent coflorescences arising from the enrichment zone of the main shoot. The whole flowering system is a synflorescence (Troll 1964: 148, Carolin 1967: 25). The order of flowering in the main florescence is acropetal, whereas it is basipetal for the terminal flowers in the enrichment zone.

The basic type in Australian Wahlenbergia is similar, but with a number of differences. It may be illustrated by $W$. communis (Figure 2). The main florescence consists of the terminal flower and the first two (not three) flowering branches below. The cymose branching of the main florescence is more extensive than in W. virgata, while fewer coflorescences develop. Also, the order of flowering is basipetal throughout the inflorescence. Thulin (1975: 20) stressed the generality among African species of acropetal flowering in the main florescence versus basipetal flowering in the enrichment zone. However, in Australia, only the introduced $W$. capensis has a consistently acropetal order of flowering in the main florescence.

Using the terminology of Briggs \& Johnson (1979), the basic inflorescence-type in Australian Wahlenbergia may be described as a complex thyrsoid.

The native species with growth-forms III and IV all have similar flowering systems to that of $W$. communis. In the species with growth-form II, the main florescence is reduced to a solitary flower or 2-3 flowers, and coflorescences are usually absent (Figure 1). The species with growth-form I also have reduced inflorescences, with solitary 
flowers in W. glabra and W. scopulicola, and inflorescences of 1-6 flowers in W. islensis.

Pedicel lengths reported here were measured from the base of the hypanthium to the third leaf organ down or the first branch, whichever was shorter.

\section{Sepals}

Most species have more or less narrowly triangular sepals that gradually taper to the apex. However, two annual species, W. gracilenta and W. preissii, are characterised by narrowly oblong sepals that narrow abruptly to an obtuse to broadly acute apex.

\section{Corolla}

The size and shape of the corolla are important diagnostic characters among Australian Wahlenbergia. There are characteristically small-flowered species of each growthform, namely, W. gracilis, W. tumidifructa, W. gracilenta, W. preissii, W. insulae-howei and $W$. islensis. These all have corollas with lobes usually $<6 \mathrm{~mm}$ long. Occasional slightly larger-flowered specimens of these species are large in all flower parts, so that the corolla still appears small in relation to the hypanthium.

Three corolla shapes may be distinguished from the relative length of tube and lobes (Figure 3). The terms used for these are: 'deeply campanulate' for corollas with lobes less than twice as long as the tube; 'shortly campanulate' for corollas with lobes about three times as long as the tube; and 'rotate' for corollas with lobes more than four times as long as the tube. Most species have campanulate corollas. Rotate corollas, combined with capitate styles, are a particular feature of three closely related species, W. fluminalis, W. multicaulis and W. planiflora.

Most species have a zone of short hairs inside the corolla tube at the base, these hairs being especially long and dense in W. capensis. Thulin (1975: 25) suggested that this may be a general feature of the genus. However, several Australian species of growthforms II and IV have entirely glabrous corollas: $W$. caryophylloides, $W$. densifolia, W. gloriosa and W. saxicola.

The normal number of corolla lobes (also sepals and stamens) is five in all species, although occasional specimens have either more or fewer lobes. There is similar variation in the colour of the corolla, with occasional white- or pink-flowered specimens of species that are normally blue-flowered. Other colour variations are more

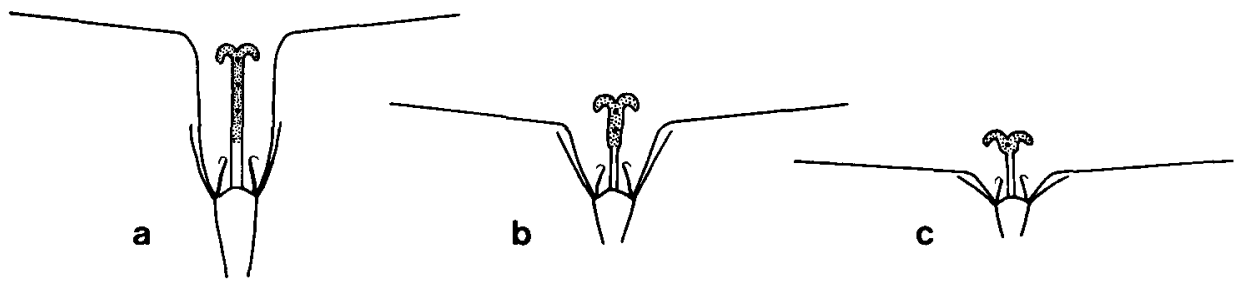

Figure 3. Flower types of Australian Wahlenbergia species. a, deeply campanulate corolla, unconstricted style (W. communis); b, shortly campanulate corolla, style constricted halfway down (W. graniticola); c, rotate corolla, style strongly constricted close to the stigmatic lobes $(W$. planiflora). 
diagnostic, particularly the dark purple of $W$. gloriosa and the greenish blue with dark blue centre of $W$. capensis.

\section{Stamens}

Von Brehmer $(1915 a, b)$ attached great importance to the shape of the dilated filament-bases as a diagnostic character for African Wahlenbergia. The overall range of filament types among Australian species is much less than among African species (as is true for most characters), but the variation within species is considerable. Some differences are apparent between species, but their value as a diagnostic character is very limited. The reliability and value of this character have also been questioned by Thulin (1975: 25) for African species.

\section{Style}

Styles in Australian Wahlenbergia are 2-, 3- or 5-fid, corresponding to the number of loculi in the ovary and capsule. The only 5-fid species is the introduced $W$. capensis. Most species are normally 3-fid. W. densifolia, W. gloriosa, W. preissii and W. saxicola are normally 2-fid. W. caryophylloides may be either 2-fid or 3-fid. Except for W. preissii, the 2-fid species are also the ones with entirely glabrous corollas (see above).

The lower style is glabrous or has scattered normal hairs, while the upper style, including the outside of the stigmatic lobes, is densely covered with coarser hairs to which the shed pollen adheres. These hairs are often termed 'pollen-collecting' (e.g. Carolin 1960), but are referred to here as 'pollen-presenting' to avoid confusion with the stigmatic hairs. The genus is distinctly protandrous, as are other members of the Campanulaceae. Pollen is shed onto the pollen-presenting hairs while the flower is in bud, and the anthers wither before the flower opens. The stigmatic lobes are erect and appressed when the flower first opens, and the stigmatic hairs are very short. The pollen-presenting hairs soon collapse and the pollen begins to fall away from the style. Meanwhile, the stigmatic hairs grow to their full length and the stigmatic lobes open to become recurved and receptive.

The lower part of the style is often narrower than the upper part, with an abrupt constriction at the junction. The position and degree of constriction are useful diagnostic characters. The three main types of style are illustrated in Figure 3 (see also the species illustrations). As indicated in the diagram, there is often a correlation between type of style and type of corolla. Thus, $W$. planiflora, $W$. fluminalis and $W$. multicaulis have a rotate corolla and a capitate style, strongly constricted close to the stigmatic lobes. W. graniticola, W. aridicola and $W$. littoricola have a shortly campanulate corolla and a more or less distinct constriction about halfway down the style. W. communis, $W$. stricta and $W$. queenslandica have a deeply campanulate corolla and a more or less unconstricted style on which the pollen-presenting zone typically extends into the lower half.

The large raised glands that may be present in the pollen-presenting zone have provided useful diagnostic characters for African Wahlenbergia in terms of their presence/absence (or apparent absence - they may be detectable only under high magnification), number and position (von Brehmer 1915a, b, Thulin 1975). These glands are generally more numerous in Australian species than in African species, but are more variable and of less value as a diagnostic character. There may be as many as 15 glands on the style, arranged in columns of up to five glands under each stigmatic cleft. The number of glands is generally correlated with the extent of the pollenpresenting zone, but often varies markedly within species, even as to presence/ absence (see species accounts). The function of the glands, whether related to adhesion of the pollen-grains to the style or attraction of pollinating insects, is unclear. 
Style lengths reported here are total lengths, including the straightened stigmatic lobes. The length of the lobes is reported separately.

\section{Capsule}

The shape of the capsule varies between species and is often a useful diagnostic character. The terms used in this account are illustrated in Figure 4. Measurements of capsule length do not include the persistent sepals.

\section{Chromosome numbers}

Two authors have reported chromosome counts for Australian Wahlenbergia species, although voucher specimens are lacking and the species identifications should be treated with caution. H. Gulline (in Darlington \& Wylie 1955: 289) reported counts of $n=9$ for $W$. gracilenta and $W$. gymnoclada, $n=18$ for $W$. stricta, $n=27$ for $W$. gracilis, and $n=36$ for $W$. saxicola. These counts were probably all from Tasmania. Want (1963: 165) reported counts of $n=18$ for 'W. bicolor' (most likely W. communis or W. luteola) and another unidentified species from north-eastern New South Wales.

A total of 111 counts were made during this study. The counts were made on meiotic stages in pollen mother cell squashes stained with propionic orcein. Another 54 counts made by $R$. Carolin prior to the study are also reported here. All counts were from sites in eastern mainland Australia. The counts are summarised in Table 1 and details of voucher specimens are provided in the species accounts.
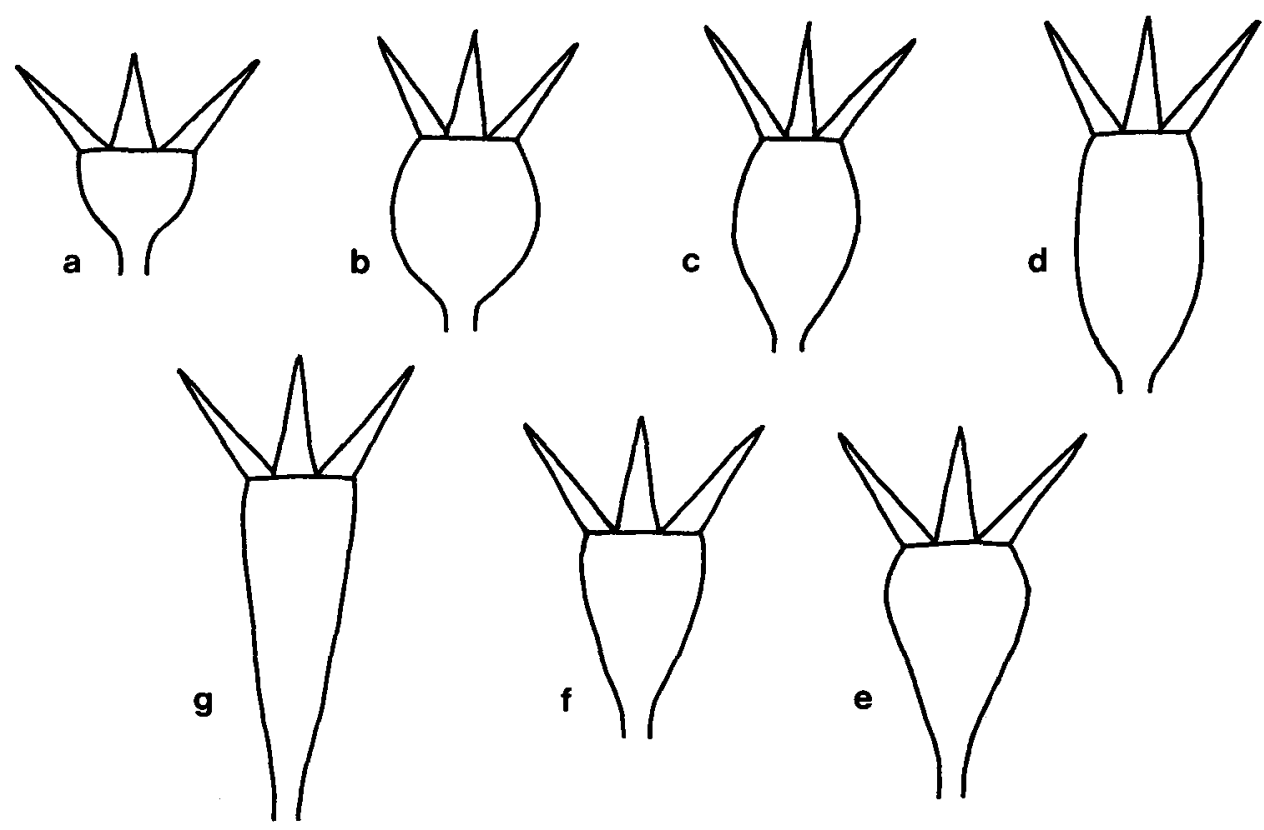

Figure 4. Capsule shapes of Australian Wahlenbergia species. a, hemispherical; b, globose; $\mathbf{c}$, ellipsoid; d, cylindrical; e, obovoid; $\mathbf{f}$, obconic; $\mathbf{g}$, elongated-obconic. 
All counts in Australian Wahlenbergia species have had a base number of $x=9$ except for one count of $n=8$ in $W$. communis, which appears to represent a local aberration arising through fusion of two chromosomes. Polyploidy is a recurring feature and four levels of ploidy have been found: diploid $(n=9)$, tetraploid $(n=18)$, hexaploid $(n=27)$ and octoploid $(n=36)$.

J. Petterson (pers. comm.) has made a series of unpublished counts on New Zealand Wahlenbergia species: $n=18$ for several species of growth-form II, and $n=36$ for several species of growth-form III. Various counts have been reported for the $W$. marginata/W. gracilis complex of southern Asia and Australasia: $n=9$ (Taiwan; Hsu 1967: 126), $n=18$ (Taiwan; Hsu 1968: 17), $n=27$ (New Guinea; Borgmann 1964: 146), $n=36$ (garden origin; Gadella 1966: 506) and $n=$ c. 45 (New Guinea; Borgmann 1964: 126). A count of $n=32$ has also been reported for this complex (garden origin; Sugiura 1942: 425), but its validity has been questioned (Thulin 1975: 44).

Table 1. Chromosome numbers in Australian Wahlenbergia species in relation to growth-form.

\begin{tabular}{|c|c|c|c|c|}
\hline \multirow[t]{2}{*}{ Taxon } & \multirow{2}{*}{$\begin{array}{l}\text { Growth-form } \\
\text { (Fig. 1) }\end{array}$} & \multirow[t]{2}{*}{$n$} & \multicolumn{2}{|c|}{ Number of counts } \\
\hline & & & Smith & Carolin \\
\hline W. scopulicola & 1 & 9 & 1 & \\
\hline W. glabra & I & 9 & 1 & \\
\hline W. islensis & 1 & 9 & 1 & \\
\hline W. ceracea & $\|$ & 9 & & 4 \\
\hline W. gloriosa & ॥ & 9 & & 1 \\
\hline W. densifolia & $\|$ & 9 & & 1 \\
\hline W. gymnoclada & $\|$ & 9 & 1 & \\
\hline \multicolumn{5}{|l|}{ W. stricta } \\
\hline \multirow[t]{2}{*}{ subsp. stricta } & III & 9 & 6 & 3 \\
\hline & & 18 & 4 & 8 \\
\hline \multirow[t]{2}{*}{ subsp. alterna } & III & 9 & 1 & \\
\hline & & 18 & 1 & 1 \\
\hline \multirow[t]{2}{*}{ W. luteola } & III & 9 & 2 & 1 \\
\hline & & 18 & 4 & 3 \\
\hline \multirow[t]{3}{*}{ W. communis } & III & $8^{\star}$ & & 1 \\
\hline & & 9 & 3 & 2 \\
\hline & & 18 & 20 & 4 \\
\hline \multirow[t]{2}{*}{ W. queenslandica } & III & 9 & 2 & \\
\hline & & 18 & 4 & \\
\hline \multirow[t]{2}{*}{ W. graniticola } & III & 9 & 5 & 1 \\
\hline & & 18 & 8 & 1 \\
\hline \multirow[t]{2}{*}{ W. aridicola } & III & 9 & 1 & \\
\hline & & 18 & 1 & 1 \\
\hline \multirow[t]{2}{*}{ W. littoricola } & III & 27 & 6 & 3 \\
\hline & & 36 & & 1 \\
\hline \multicolumn{5}{|l|}{ W. planiflora } \\
\hline subsp. planiflora & III & $\begin{array}{l}18 \\
27\end{array}$ & 3 & $\begin{array}{l}1 \\
1\end{array}$ \\
\hline \multirow[t]{2}{*}{ subsp. longipila } & III & 9 & 1 & 1 \\
\hline & & 18 & 5 & 1 \\
\hline W. fluminalis & III & 18 & 5 & 1 \\
\hline \multirow[t]{3}{*}{ W. multicaulis } & III & 18 & 1 & \\
\hline & & 27 & 6 & 3 \\
\hline & & 36 & & 1 \\
\hline W. gracilis & III & 27 & 8 & 4 \\
\hline W. tumidifructa & III/IV & 27 & 9 & 5 \\
\hline W. gracilenta & IV & 18 & 2 & \\
\hline
\end{tabular}

* One chromosome very large. 
It thus appears that $x=9$ is the base number for Wahlenbergia species throughout Australasia and southern Asia, and that polyploidy is common throughout. By contrast, Thulin (1975: 45) reported base numbers among African Wahlenbergia of $x=7$ ( 2 taxa), $x=8$ (10 taxa) and $x=9$ ( 3 taxa), with only one example of polyploidy. A base number of $x=9$ is otherwise rare among genera of the Campanulaceae (Darlington \& Wylie 1955).

Counts on Australian species of growth-forms I and II have been consistently diploid, except for Gulline's unconfirmed octoploid count in W. saxicola. On the other hand, all species of growth-form III are partly or entirely polyploid, with most species having at least two chromosome races. The only species of growth-form IV that has been examined, W. gracilenta, also appears to have at least two chromosome races, with tetraploid counts made during this study and an unconfirmed diploid count reported by Gulline.

It appears that speciation in Australian Wahlenbergia has occurred mainly at the diploid level, followed by extensive development of polyploid races within species, particularly those of growth-form III. A subsequent phase of speciation at the polyploid level is indicated by the species (and subspecies) of growth-form III for which
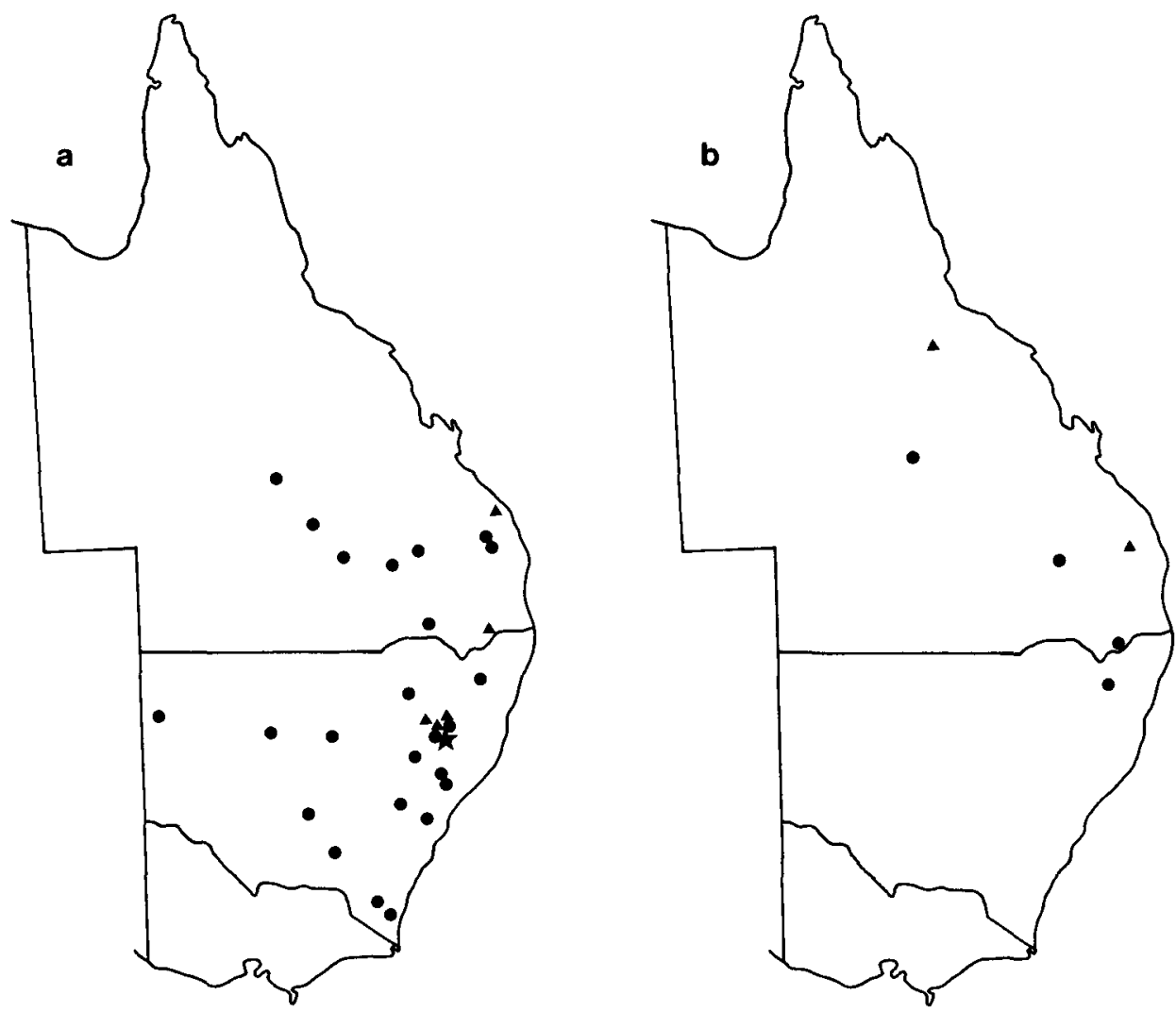

Figure 5. Geographic distribution of chromosome counts. a, W. communis; b, W. queenslandica. Star: $n=8$; triangle: $n=9$; circle: $n=18$. 
only polyploid counts have been made. Tetraploid W. fluminalis, tetraploid/hexaploid/octoploid W. multicaulis and tetraploid/hexaploid W. planiflora subsp. planiflora are morphologically very close to each other and to diploid/tetraploid W. planiflora subsp. longipila. Hexaploid/octoploid W. littoricola is close to diploid/tetraploid W. graniticola and diploid/tetraploid W. aridicola.

The only polyploid taxa of growth-form III which are not clearly linked to known diploid forms are $W$. gracilis and W. tumidifructa, two closely related species for which only hexaploid counts have been made in Australia. There has been an unpublished octoploid count on W. gracilis material from New Caledonia (J. Petterson, pers. comm.). This species also occurs in New Zealand, New Guinea and possibly elsewhere. It may well have originated at the diploid level outside Australia. W. tumidifructa would seem to be an Australian arid-zone derivative of hexaploid $W$. gracilis.

The geographic distribution of the chromosome races in 12 taxa of growth-form III are illustrated in Figures 5-7. There is a concentration of diploid races in northeastern New South Wales and eastern Queensland, suggesting that this was the original centre of diversity of the group in Australia. The development of tetraploid races has apparently resulted in a general expansion of the species southwards and westwards, accompanied by morphological differentiation at the tetraploid level in the
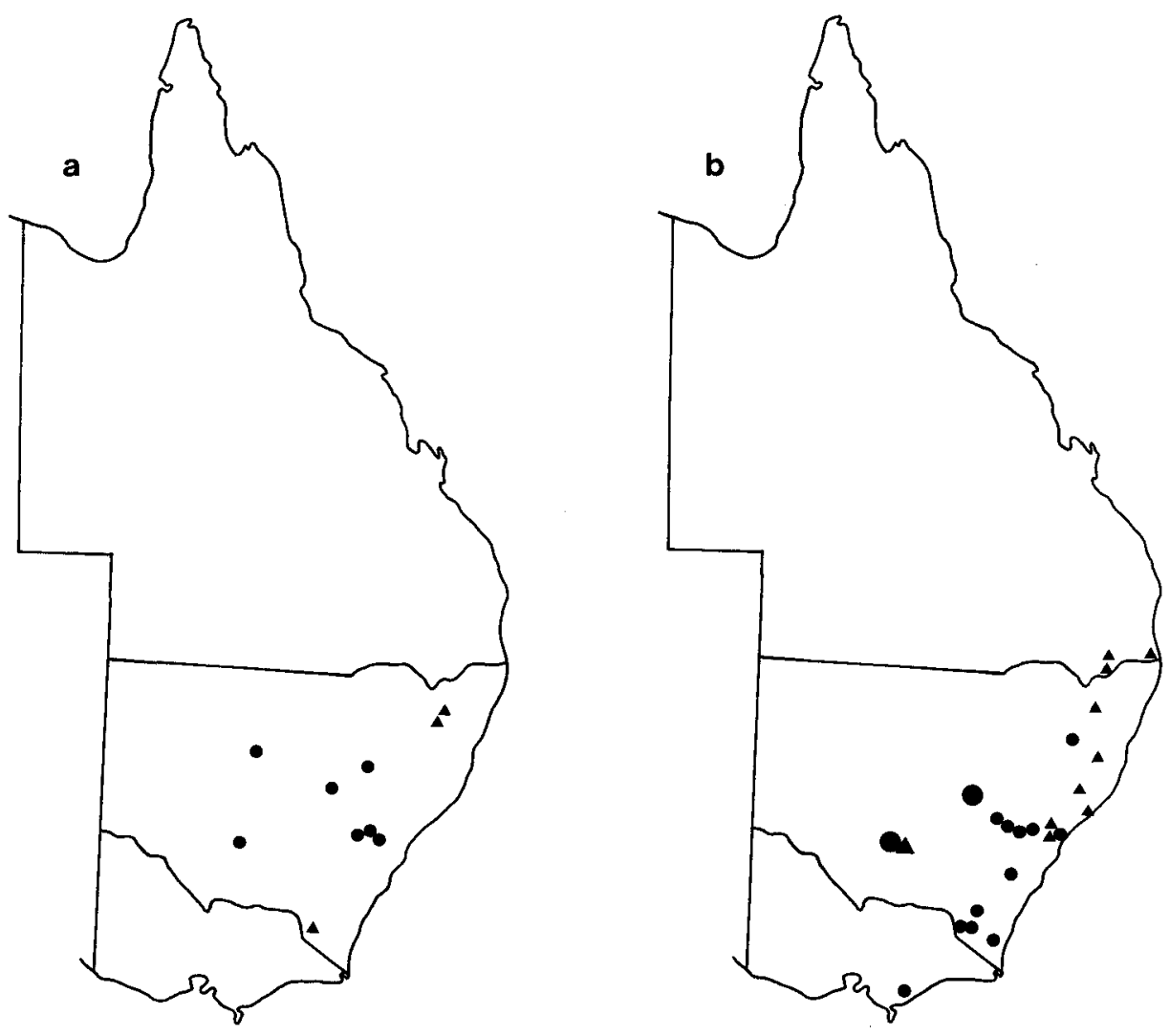

Figure 6. Geographic distribution of chromosome counts. $\mathbf{a}, W$. luteola; $\mathbf{b}, W$ stricta subsp. stricta (small symbols) and subsp. alterna (large symbols). Triangle: $n=9$; circle: $n=18$. 
W. planiflora/W. fluminalis / W. multicaulis complex, and development of hexaploid and octoploid forms in this complex and W. littoricola.

Species of growth-form III often grow in disturbed sites such as roadsides. In a couple of instances, diploid and tetraploid races were found growing in close proximity, with the diploids in relatively undisturbed sites and the tetraploids on roadsides or erosion gutters. This occurred in W. stricta subsp. alterna in the Cocoparra Range, and in W. planiflora subsp. longipila in the Nandewar Range. However, there were also many instances of diploids growing in highly disturbed sites (including diploid $W$. planiflora subsp. longipila), indicating that the ability to colonise such sites is by no means a characteristic solely of the polyploid races

Some general features of hexapioids became apparent from observations of glasshouse plants. Hexaploid plants grow to maturity much more rapidly than either diploids or tetraploids. For example, for a variety of taxa germinating in the glasshouse over a one month period in autumn, the mean time until first flowering was $108 \pm$ SD 16 days for hexaploids (10 samples, 4 taxa), compared with $168 \pm 32$ days for tetraploids (9 samples, 8 taxa) and $171 \pm 44$ days for diploids ( 6 samples, 5 taxa).
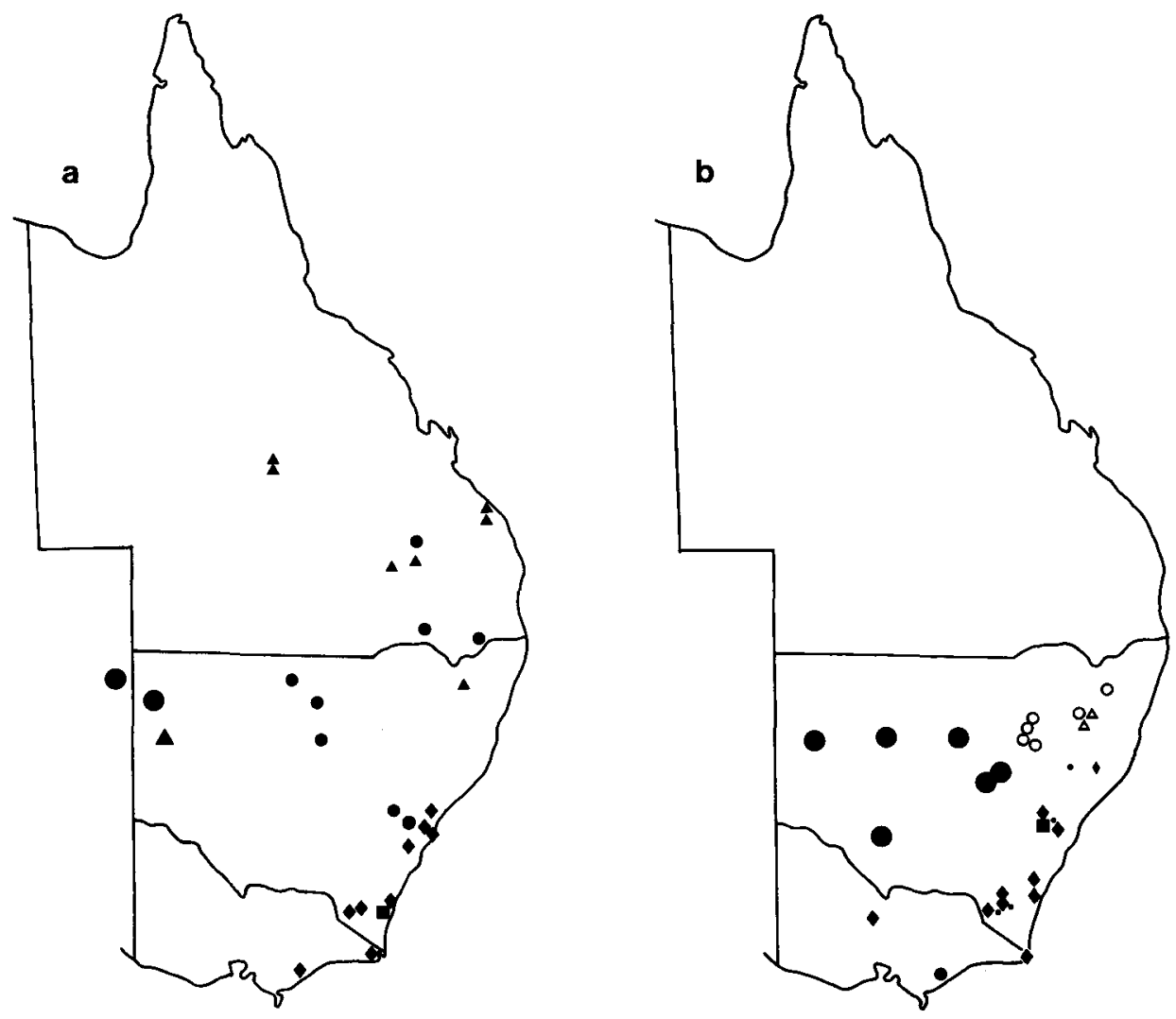

Figure 7. Geographic distribution of chromosome counts. a, W. graniticola (small $\boldsymbol{\Delta}$ and $\bullet$ ), $W$. aridicola (large $\boldsymbol{\Delta}$ and $\bullet$ ) and $W$. littoricola $(\bullet$ and $\mathbf{\square}$ ); $\mathbf{b}$, W. planiflora subsp. planiflora (small closed symbols), subsp. longipila (open symbols), W. fluminalis(large closed symbols) and W. multicaulis (medium closed symbols). Triangle: $n=9$; circle: $n=18$; diamond: $n=27$; square: $n=36$ 
These differences between hexaploids and tetraploids/diploids are statistically significant ( $\mathrm{t}$-tests, $\mathrm{p}<0.05$ ).

The flowers of hexaploids regularly self-fertilise by the stigmatic lobes opening and recurving while there is still viable pollen on the outside of the style. The stigmatic lobes open much later in diploid and tetraploid flowers, and these fail to set seed in the absence of pollinators. This was demonstrated by exclosure experiments in the glasshouse. The flowers of hexaploid W. gracilis, W. littoricola, W. multicaulis and $W$. tumidifructa all regularly self-fertilised and produced fertile progeny, but never those of the various diploid and tetraploid taxa that were tested. However, artificial selfings by transfer of pollen between flowers showed that at least three diploid taxa and five tetraploid taxa are self-compatible and thus capable of self-fertilisation in the presence of pollinators.

Hexaploids also hybridise more readily than do diploids and tetraploids. This was demonstrated in a series of attempted crosses in the glasshouse. All 25 attempts between diploids ( 6 species) were unsuccessful; 45 attempts between tetraploids ( 7 species) resulted in a single hybrid between the closely related $W$. fluminalis and W. planiflora subsp. planiflora; while various hybrids (all infertile) were obtained in 25 of 37 attempts between the four hexaploid species. These differences are statistically significant (chi-squared test, $\mathrm{p}<0.001$ ).

The extent of hybridisation among Australian Wahlenbergia species is difficult to gauge. Only one hybrid is described in the species accounts, namely W. gloriosa X W. stricta. These are two distinctive species and the hybrid specimens can be fairly readily identified. In general, however, the similarities and variability of the species make it difficult to identify hybrid specimens with any certainty. Wherever there has been doubt I have assigned specimens to species rather than to putative hybrids. During fieldwork I have encountered instances of hybrid swarms forming between hexaploid species such as $W$. gracilis and $W$. littoricola, but obvious examples have been few. I would suggest, as did Lothian (1947a: 205), that hybridisation is a less extensive phenomenon among Australian Wahlenbergia species than is often supposed.

\section{Distribution}

Wahlenbergia is widespread in Australia and probably occurs in every one-degree grid-square on the continent, although with marked differences in the numbers of taxa (Figure 8). The distribution of the taxa in relation to major phytogeographic zones (Barlow 1986) is summarised in Table 2.

The greatest concentration of species is in the South-eastern Zone, where there are 21 taxa, eight of which are local endemics, including five of the six species of growthform II and two of the three species of growth-form I. Overall, 14 taxa appear to have originated within this zone, and a further three taxa in the overlap area between this zone and the North-eastern Zone. These include representatives of all four growthforms. A southern origin within the zone is indicated for taxa of growth-forms II and IV, while a predominantly northern origin is indicated for taxa of growth-forms I and III.

Ten taxa occur in the North-eastern Zone. These include one endemic species of growth-form I ( $W$. islensis); one widespread species of growth-form III that is likely to have originated within the zone ( $W$. queenslandica); and, as noted above, three other species of growth-form III that are likely to have originated in the overlap area between this zone and the South-eastern Zone. 
Only five taxa occur in the Northern Zone. However, one species, W. caryophylloides, is restricted to this zone and the adjacent North-eastern Zone. At present this species is only known from Australia, but it may well occur, and may even have originated, to the north of Australia.

Sixteen taxa occur in the Eyre-Murray Zone, making it the second richest zone for Wahlenbergia. Four taxa of growth-form III have apparently originated within this zone. All four are closely related to taxa from more mesic regions further east: $W$. aridicola is close to $W$. graniticola, W. fluminalis to W. planiflora, W. tumidifructa to $W$. gracilis, and W. stricta subsp. alterna to subsp. stricta.

Only four taxa occur in the Western Shield Zone. All four are widespread species that have apparently colonised the area from eastern Australia.

Nine taxa occur in the South-western Zone. These include two introduced species: $W$. capensis from South Africa, and W. stricta subsp. stricta from eastern Australia. Only one species, W. preissii, appears to have originated within the zone. This species is closely related to another species of growth-form IV, W. gracilenta, whose apparent origins are in south-eastern Australia.

Only two taxa occur on Lord Howe Island, including one endemic species of growthform II, W. insulae-howei.

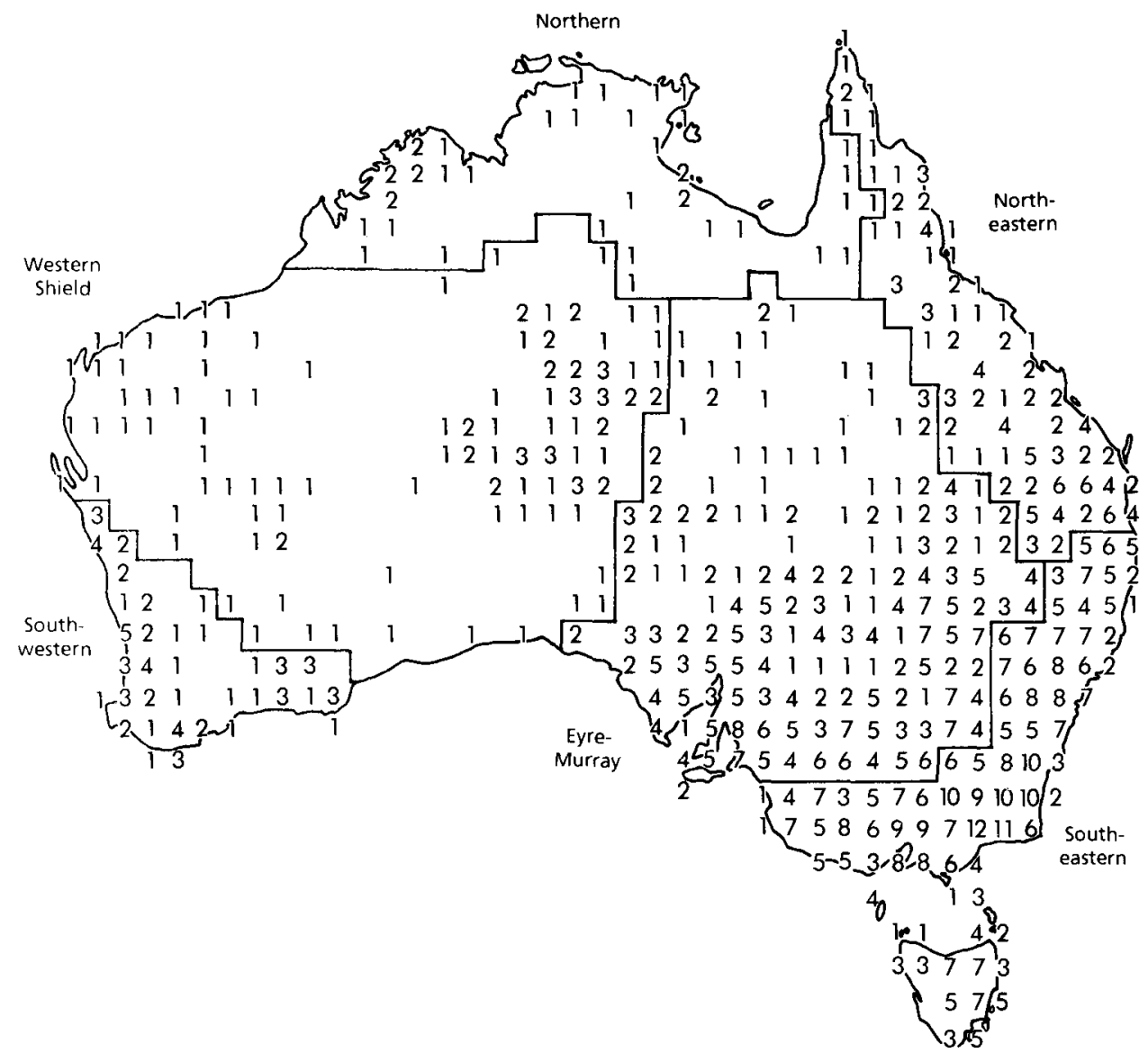

Figure 8. Number of Wahlenbergia taxa (species or subspecies) recorded in each one-degree grid-square. Also shown are the major phytogeographic zones as defined by Barlow (1986). 


\section{Relationships}

No satisfactory subgeneric classification of Wahlenbergia has yet been developed. De Candolle (1839), revising his earlier classification (de Candolle 1830), recognised six sections in Wahlenbergia sens. strict. One of these has since been transferred to Codonopsis, and four others had only one species each. The great majority of species were classified in a single section, Aikinia, including all the native Australian species and $W$. capensis.

Von Brehmer (1915a) distinguished 30 'series' of Wahlenbergia sens. strict. in Africa, but these were found to be of little value in the subsequent study by Thulin (1975: 1415). Thulin noted a correlation among African species between basic chromosome

Table 2. Distribution of Australian Wahlenbergia species in relation to the phytogeographic zones of Barlow (1986).

\begin{tabular}{|c|c|c|c|c|c|c|c|c|}
\hline Taxon & Growth-form & & & ytog & gra & ic 20 & & \\
\hline & (Fig. 1) & LHI & SE & NE & $\mathrm{N}$ & EM & WS & SW \\
\hline W. scopulicola & 1 & & lel & & & & & \\
\hline W. glabra & I & & lel & & & & & \\
\hline W. islensis & I & & & lel & & & & \\
\hline W. ceracea & II & & lel & & & & & \\
\hline W. gloriosa & II & & lel & & & & & \\
\hline W. densifolia & ॥ & & |el & & & & & \\
\hline W. gymnoclada & ॥ & & lel & & & & & \\
\hline W. saxicola & $\|$ & & lel & & & & & \\
\hline W. insulae-howei & $\|$ & lel & & & & & & \\
\hline W. stricta & & & & & & & & \\
\hline subsp. stricta & III & & It & +1 & & + & & $-i$ \\
\hline subsp. alterna & |II & & - & & & $1+1$ & & \\
\hline W. luteola & III & & $1+1$ & & & + & & \\
\hline W. communis & III & & It & +1 & - & + & + & - \\
\hline W. queenslandica & III & & - & $1+1$ & + & + & + & - \\
\hline W. graniticola & III & & It & +1 & & + & & \\
\hline W. aridicola & III & & & & & lel & & \\
\hline W. littoricola & III & & $1+1$ & & & + & & + \\
\hline W. planiflora & & & & & & & & \\
\hline subsp. planiflora & III & & lel & & & & & \\
\hline subsp. longipila & III & & $1+1$ & - & & - & & \\
\hline W. fluminalis & $\mathrm{III}$ & & + & - & & $1+1$ & & \\
\hline W. multicaulis & III & & $1+1$ & & & - & & + \\
\hline W. gracilis & III & - & + & + & - & - & & \\
\hline W. tumidifructa & III/IV & & & - & - & $|+|$ & + & - \\
\hline W. gracilenta & IV & & $1+1$ & & & + & - & + \\
\hline W. preissii & IV & & & & & - & & $1+1$ \\
\hline W. victoriensis & IV & & $|+|$ & & & - & & \\
\hline W. caryophylloides & IV & & & + & + & & & \\
\hline *W. capensis & IV & & & & & & & $+i$ \\
\hline Total taxa & & 2 & 21 & 10 & 5 & 16 & 4 & 9 \\
\hline Endemic taxa & & 1 & 8 & 1 & 0 & 1 & 0 & 0 \\
\hline Introduced taxa & & 0 & 0 & 0 & 0 & 0 & 0 & 2 \\
\hline
\end{tabular}

LHI, Lord Howe Island; SE, South-eastern; NE, North-eastern; N, Northern; EM, Eyre-Murray; WS, Western Shield; SW, South-western; +, major occurrence; -, minor occurrence; e, endemic; i, introduced; I I, likely site of origin (based on distribution and chromosome number data). 
number and some important morphological characters. He refrained from making a formal subdivision of the genus until more information was available, but placed species into informal groups reflecting their supposed natural affinities.

Thulin (1975: 76) suggested a relationship between his $W$. undulata (L. f.) A. DC. Group and the Asian W. marginata complex and related species in Australia. The W. undulata Group consists of six species and is characterised by a basic chromosome number of $x=9$, a distinct corolla-tube and usually stylar glands. The group is distributed in almost all parts of Africa and also in southern Europe. It includes W. undulata, W. virgata (Figure 2) and other species from de Candolle's (1839) section Aikinia. It also includes W. lobelioides (L. f.) A. DC., which had been classified by de Candolle in a separate, monotypic section, Lobelioides.

The results of the present study support Thulin's contention. The general affinities of all native Australian species would seem to be with the W. undulata Group of Africa. However, the introduced $W$. capensis, with its pentamerous gynoecium, is distinct from both the native species and the African species considered by Thulin. Other species of this type occur in South Africa, but none is included in Thulin's treatment, which only deals with the tropical African species.

Within Australia, the morphological and cytological evidence indicates four groups of related native species corresponding to the four major growth-forms (Figure 1). Three subgroups may also be distinguished within one of these groups. The species order used in the taxonomic treatment reflects these putative relationships. The groups are:

The W. scopulicola Group, consisting of W. scopulicola, W. glabra and W. islensis. These are three distinctive species with very restricted distributions in north-eastern temperate Australia. All grow in rock crevices and are characterised by growth-form I. Other shared characters are deeply campanulate corollas and hemispherical capsules. A single diploid count has been made on each species.

The W. gloriosa Group, consisting of W. ceracea, W. gloriosa, W. densifolia, W. gymnoclada, W. saxicola and W. insulae-howei. These six species are characterised by growthform II. One species is endemic to Lord Howe Island; the others are endemic to south-eastern Australia. All are distinctive species with more or less restricted distributions, typically occurring in natural habitats at high montane to alpine levels. All chromosome counts have been diploid except for an unconfirmed octoploid count in $W$. saxicola. Related species, also typically associated with higher altitudes, are found in New Guinea (W. papuana P. Royen) and New Zealand (W. albomarginata Hook., W. brockiei J. Hay, W. cartilaginea Hook. f., W. congesta (Cheeseman) N.E. Br., W. matthewsii Cockayne, W. pygmaea Colenso and W. simpsonii J. Hay). Chromosome counts on the New Zealand species have all been tetraploid (J. Petterson, pers. comm.), suggesting a spread of the group from Australia to New Zealand rather than the reverse.

The $W$. communis Group, consisting of 12 species characterised by growth-form III. Most species have two or more chromosome races. All are partly or entirely polyploid, and at least seven species have diploid races as well. Most species have wide distributions and grow in a variety of vegetation types, often in disturbed sites. There is a concentration of diploid races in north-eastern temperate Australia, suggesting that this was the original centre of diversity of the group in Australia. Several species extend outside Australia and related species occur elsewhere (e.g. W. marginata of Japan). This group is badly in need of revision in Asia, Malesia and New Zealand. Poor knowledge of the taxa in these regions makes it difficult to assess the extent to which Australian taxa are represented there. 
The Australian members of the group are W. stricta, W. luteola, W. communis, $W$. queenslandica and three subgroups of closely related species. The W. graniticola Subgroup, consisting of W. graniticola, W. aridicola and W. littoricola, is characterised by medium to large, shortly campanulate corollas, and styles that are more or less distinctly constricted about halfway down. The W. planiflora Subgroup, consisting of $W$. planiflora, W. fluminalis and W. multicaulis, is characterised by rotate corollas and capitate styles, strongly constricted close below the stigmatic lobes. The $W$. gracilis Subgroup, consisting of W. gracilis and W. tumidifructa, is characterised by small, deeply campanulate corollas and more or less unconstricted styles. There appears to have been speciation at the polyploid level in all three subgroups, but not among other Australian members of the W. communis Group. Hexaploid and octoploid forms have developed in all three subgroups, but are unknown in other Australian members of the group.

The W. gracilenta Group, consisting of W. gracilenta, W. preissii, W. victoriensis and W. caryophylloides. These species are characterised by growth-form IV, i.e. they are consistently annual. They also all have opposite, more or less elliptic, more or less hirsute lower leaves. W. gracilenta and W. preissii both have distinctive, narrowly oblong sepals with obtuse to broadly acute apices. W. gracilenta and $W$. victoriensis both have lanceolate bracteoles and ellipsoid to globose capsules. These three species all have southern distributions, with a south-eastern origin indicated for W. gracilenta and W. victoriensis, and a south-western origin indicated for W. preissii. W. caryophylloides has a northern distribution and is less clearly related to the other species of the group. There have been tetraploid counts and an unconfirmed diploid count for W. gracilenta, but no counts for the other species.

\section{Taxonomy}

\section{Wahlenbergia}

Wahlenbergia Schrader ex Roth (1821: 399), nom. cons. (I.C.B.N. 1988: 275); de Candolle (1830: 142), (1839: 424); von Brehmer (1915a: 9), (1915b: 72); Lothian (1947a: 201); van Steenis (1960: 122); Tuyn (1960: 111); Carolin (1964: 235); Thulin (1975: 1). Wahlenbergia Schrader (1814: 3), nom. nud.

TYPE: W. elongata (Willd.) Schrader ex Roth, nom. illeg. $\equiv$ W. capensis (L.) A. DC.

Campanula Linnaeus (1753: 169), p.p.; auct. mult.

Cephalostigma de Candolle (1830: 117). TYPE: C. perrottetii A. DC. $\equiv W$. perrottetii (A. DC.) Thulin.

[Lightfootia L'Héritier (1789: 4), nom. illeg. Non Swartz (1788: 83). TYPE: L. oxycoccoides L'Hérit. $\equiv$ L. parvifolia (Berg) Adamson]

[Cervicina Delile (1813: 7), nom. rej. TYPE: C. campanuloides Delile $\equiv$ W. campanuloides (Delile) Vatke]

[Campanopsis (R.Br.) Kuntze (1891: 378), nom. illeg. Campanula (sect.) I. Campanopsis R. Brown (1810: 561), nom. nud.]

The following description covers only the Australian species.

Annual or perennial herbs, tufted or rhizomatous. Taproot slender and soft in annual or young plants, becoming thickened and woody with age. Stems one to many, usually erect or ascending, sometimes decumbent or pendent, branched or unbranched, 
terete, usually faintly ribbed with decurrent leaf margins, glabrous to hirsute; hairs simple, white. Leaves and bracts simple, exstipulate, confined to basal rosettes in some species but usually spread along stem, becoming smaller and more widely spaced on upper stem, alternate throughout or opposite on lower stem becoming alternate above or irregularly opposite and alternate, typically changing in shape from broadest distally at base of stem to broadest proximally on upper stem, obtuse to subulate, usually sessile but shortly petiolate in one species, glabrous to hirsute, midrib obscure on upper surface, usually prominent below, at least on lower leaves, lateral venation obscure; margins flat or undulate, \pm cartilaginous, entire or with small, distant callusteeth, sometimes \pm serrate. Flowers terminal, solitary or in cymes or thyrsoids of varying complexity, actinomorphic, bisexual, protandrous; pedicels usually \pm glabrous, with two small, alternate bracteoles. Hypanthium not extended above the ovary, glabrous to hirsute. Sepals usually 5, free, erect or spreading, usually \pm narrowly triangular, sometimes narrowly oblong, glabrous to hirsute, persistent in fruit. Corolla campanulate or rotate, usually blue, darker in colour on inner surface of lobes, entirely glabrous in some species but usually puberulous inside tube at base, sometimes also sparsely hirsute along veins; lobes usually 5, spreading, ovate to obovate, usually acute. Stamens usually 5, free; filaments persistent in open flower, usually white but dark blue in one species, upper section filiform and glabrous, lower section expanded, triangular to obtrullate, with or without extended shoulders, usually ciliate on upper margins; anthers basifixed, with 2 cylindrical cells, dehiscing and wilting before the flower opens, dehiscence introrse by longitudinal slits. Ovary inferior, usually 2- or 3locular but 5-locular in one species; ovules numerous; placentation axile. Style usually white and 2- or 3-fid but dark blue and 5-fid in one species, unconstricted or with a constriction of varying degree and location separating the pollen-presenting upper section of the style from the narrower, non-pollen-presenting lower section, lower style glabrous or with scattered normal hairs, upper style densely covered with coarse pollen-presenting hairs bearing shed pollen when the flower first opens, the hairs later wilting and the pollen falling, a column of 1-5 raised glands in the pollenpresenting zone below each stigmatic cleft or glands absent; stigmatic lobes erect and appressed when flower first opens, later becoming recurved and receptive, inner surface puberulous with glandular hairs. Fruit a capsule bearing the persistent sepals, opening by apical slits, glabrous to hirsute. Seeds numerous, compressed-ellipsoid, dark brown at maturity, smooth, shining.

About 200 species, mostly in the southern hemisphere, especially Africa. Twenty-six species in Australia, 22 species apparently endemic (but note that knowledge of the taxa in surrounding regions is poor, especially for the W. communis Group), one species introduced from South Africa.

\section{Key to species}

2 Stems much-branched; flowers solitary or in few-flowered cymes; inflorescence confined to the upper third of the stem, pedicels $\leq 5 \mathrm{~cm}$ long; tufted perennials growing in rock crevices in Queensland and north-eastern New South Wales

2* Habit and inflorescence various but never a combination of much-branched stems with single- or few-flowered inflorescences 
3 Leaves hirsute, petiolate, elliptic

1. W. scopulicola

$3^{*}$ Leaves glabrous, sessile, linear or narrowly elliptic

4 Stems decumbent or pendent; corolla-lobes 5.5-9 $\mathrm{mm}$ long; leaves partly opposite, narrowly elliptic, up to $4 \mathrm{~mm}$ wide

2. W. glabra

$4^{*}$ Stems ascending; corolla-lobes $3.5-5.5 \mathrm{~mm}$ long; leaves all alternate, linear, $\leq 1.5$ mm wide

3. $W$. islensis

5 Rhizomatous perennials (although $W$. insulae-howei becoming tufted when growing in rock crevices); aerial stems and inflorescence unbranched or only sparingly branched

5* Tufted perennials or annuals; stems usually becoming much-branched, at least in the inflorescence (sometimes unbranched in small annuals)

6 Leaves linear or narrowly oblong, $\leq 2 \mathrm{~mm}$ wide (sometimes lowermost slightly wider in W. gymnoclada)

$6^{*}$ Lower leaves obovate to narrowly elliptic, $>2 \mathrm{~mm}$ wide

7 All leaves $\leq 15 \mathrm{~mm}$ long; style usually 2 -fid

6. W. densifolia

$7^{*}$ Most leaves $>15 \mathrm{~mm}$ long; style 3-fid 7. W. gymnoclada

8 Corolla-lobes 10-25 mm long; pedicels (4-)8-40 cm long; leaves rarely confined to basal rosettes

$8^{*}$ Corolla-lobes 3-11 mm long; pedicels $2-10 \mathrm{~cm}$ long; leaves often confined to basal rosettes

9 Corolla blue; style 3-fid; leaves all alternate, margins \pm flat; capsules obconic 4. W. ceracea

9* Corolla purple; style usually 2-fid; some leaves usually opposite, margins usually undulate; capsules elongated-obconic

5. W. gloriosa

10 Style usually 2-fid; corolla-tube similar in length to the sepals; endemic to Tasmania

8. W. saxicola

$10^{*}$ Style 3-fid; corolla-tube distinctly longer than the sepals; endemic to Lord Howe Island

9. W. insulae-howei

11 Corolla rotate, lobes $>4$ times as long as the tube; style capitate, deeply constricted less than a third of the way down from the stigmatic lobes

$11^{*}$ Corolla campanulate, lobes $<4$ times as long as the tube; style unconstricted or constricted more than a third of the way down from the stigmatic lobes $\quad . . . . .14$

12 Capsules elongated-obconic, more than twice as long as broad; corolla-lobes 2-9 $\mathrm{mm}$ long, less than twice as long as the hypanthium; mesic regions of southeastern and south-western Australia

19. W. multicaulis

$12^{*}$ Capsules hemispherical to obconic, less than twice as long as broad; corolla-lobes more than twice as long as the hypanthium 
13 Corolla-lobes 6-14 mm long; lower leaves obovate to narrowly elliptic, up to 11 $\mathrm{mm}$ wide; plants typically few-stemmed; mesic regions of eastern Australia

17. W. planiflora

13*Corolla-lobes 3-9 mm long; lower leaves oblanceolate to linear, $\leq 5 \mathrm{~mm}$ wide; plants typically many-stemmed; inland floodplains of the Murray-Darling Basin

18. W. fluminalis

14 Lower leaves opposite, linear; capsules elongated-obconic, at least 3 times as long as broad

11. W. luteola

$14^{*}$ Lower leaves alternate or, if opposite, then broader than linear and capsules less than 3 times as long as broad

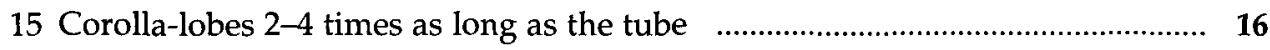

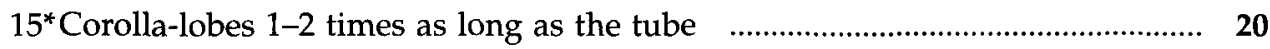

16 Annuals with slender taproots, often single-stemmed; lower leaves opposite; cap-

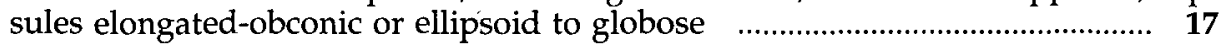

$16 *$ Perennials developing thickened, woody taproots, few- to many-stemmed; lower leaves alternate (sometimes the lowermost opposite); capsules hemispherical to obconic

17 Corolla-lobes 1.5-4 mm long; capsules elongated-obconic; Western Australia and South Australia

23. W. preissii

$17^{*}$ Corolla-lobes 6-12 mm long; capsules ellipsoid or globose; New South Wales and Victoria 24. W. victoriensis

18 Lower leaves oblanceolate to linear, $\leq 4 \mathrm{~mm}$ wide; corolla-lobes $5-9 \mathrm{~mm}$ long; mesic regions 16. W. littoricola

$18^{*}$ Lower leaves obovate to narrowly elliptical, up to $15 \mathrm{~mm}$ wide; corolla-lobes $5-19$ $\mathrm{mm}$ long

19 Corolla-lobes 6-19 mm long; plants hirsute, typically few-stemmed; mesic and semi-arid regions 14. W. graniticola

19*Corolla-lobes 5-8 $\mathrm{mm}$ long; plants glabrous to sparsely hirsute, typically manystemmed; arid regions

15. W. aridicola

20 Corolla-lobes 6-20 mm long

$20^{*}$ Corolla-lobes $0.5-6 \mathrm{~mm}$ long

21 At least the lowermost leaves opposite, margins typically undulate; sepals 3-16 $\mathrm{mm}$ long; capsules ellipsoid or globose, often hirsute

10. W. stricta

$21^{*}$ Leaves alternate, margins typically flat; sepals $1-6 \mathrm{~mm}$ long; capsules hemispherical, obconic or elongated-obconic, always glabrous

22 Capsules obconic to elongated-obconic, 4-9 mm long; lower leaves mostly linear 12. $W$. communis

$22^{*}$ Capsules hemispherical to shortly obconic, $1.5-5 \mathrm{~mm}$ long; lower leaves broader than linear 13. W. queenslandica 
23 Annuals with slender taproots, often single-stemmed

$23^{*}$ Perennials developing thickened, woody taproots, few- to many-stemmed

24 Sepals narrowly oblong; capsules often hirsute; lower leaves opposite; mesic and semi-arid regions of southern Australia 22. W. gracilenta

$24 *$ Sepals narrowly triangular; capsules glabrous 25

25 Lower leaves alternate; corolla-tube shorter than the lobes; arid and semi-arid regions

21. W. tumidifructa

$25^{*}$ Lower leaves opposite; corolla-tube often longer than the lobes; wetter tropical regions

25. W. caryophylloides

26 Capsules obconic to obovoid; mesic regions

20. W. gracilis

$26^{*}$ Capsules globose to cylindric, often very swollen; arid and semi-arid regions 21. W. tumidifructa

1. Wahlenbergia scopulicola Carolin ex P.J. Smith, sp. nov.

Herba perennis, hirsuta. Caules numerosi, decumbentes vel pendentes, ramosissimi, 5-35 cm longi. Folia irregulariter opposita et alterna, elliptica pro maxima parte, 3-20 $\mathrm{mm}$ longa, 0.5-5 mm lata, breviter petiolata. Flores solitarii, pedicellis $1-5 \mathrm{~cm}$ longis. Sepala 5, erecta vel effusa, 1.5-3 mm longa. Corolla campanulata, caerulea, tubo 3.5$6 \mathrm{~mm}$ longo, lobis 5, 5-9 mm longis. Capsula hemisphaerica, 2-5 mm longa.

Type: Queensland/New South Wales: Moreton/North Coast: Mt Lindesay, R.C. Carolin 964, 31 May 1959; holo NSW.

[W. scopulicola Carolin ex Beadle (1984: 769), nom. nud.]

[W. species D, Jacobs \& Pickard (1981: 96)]

[W. species 2, Stanley \& Ross (1986: 475)]

[W. species 3, Briggs \& Leigh (1988: 28)]

Perennial herb with a thickened taproot, tufted, many-stemmed. Stems 5-35 cm long, decumbent or pendent, crowded, much-branched, hirsute; hairs to $1 \mathrm{~mm}$ long. Leaves irregularly opposite and alternate, elliptic, becoming narrowly elliptic at top of stem, obtuse to acute, \pm petiolate, $3-20 \mathrm{~mm}$ long (including petiole up to $2 \mathrm{~mm}$ long), $0.5-$ $5 \mathrm{~mm}$ wide, hirsute; margins flat, entire or with small, distant callus-teeth. Flowers solitary; pedicels 1-5 cm long, glabrous, without bracteoles. Hypanthium hemispherical, $0.5-2.5 \mathrm{~mm}$ long, \pm glabrous. Sepals 5 , erect or spreading, \pm narrowly triangular, 1.5-3 mm long, \pm glabrous. Corolla deeply campanulate, blue, puberulous inside at base, otherwise glabrous; tube 3.5-6 mm long, longer than the sepals; lobes 5, elliptic to ovate, acute, 5-9 mm long, 2.5-3.5 mm wide. Stamens 5; filaments white, 1.0-1.6 $\mathrm{mm}$ long, upper section filiform, lower section trullate to rhombic, with or without extended shoulders, ciliate on upper margins; anthers 2-4 mm long. Ovary 3-locular. Style white, 4-7 mm long, 3-fid, indistinctly constricted $1 / 2$ to $2 / 3$ down from the stigmatic lobes, covered with pollen-presenting hairs above the constriction, $0-1$ gland below each stigmatic cleft; stigmatic lobes $0.5-1.3 \mathrm{~mm}$ long. Capsule hemispherical, 2$5 \mathrm{~mm}$ long, $2.5-4.5 \mathrm{~mm}$ wide, \pm glabrous. Seeds c. $0.6 \mathrm{~mm}$ long. Figure $9 \mathrm{a}-\mathrm{d}$.

Chromosome NUMBer: $n=9$ (Smith 57).

FLOWERING PERIOD: Throughout the year (records for Mar, May, June, Sep, Nov, Dec). 

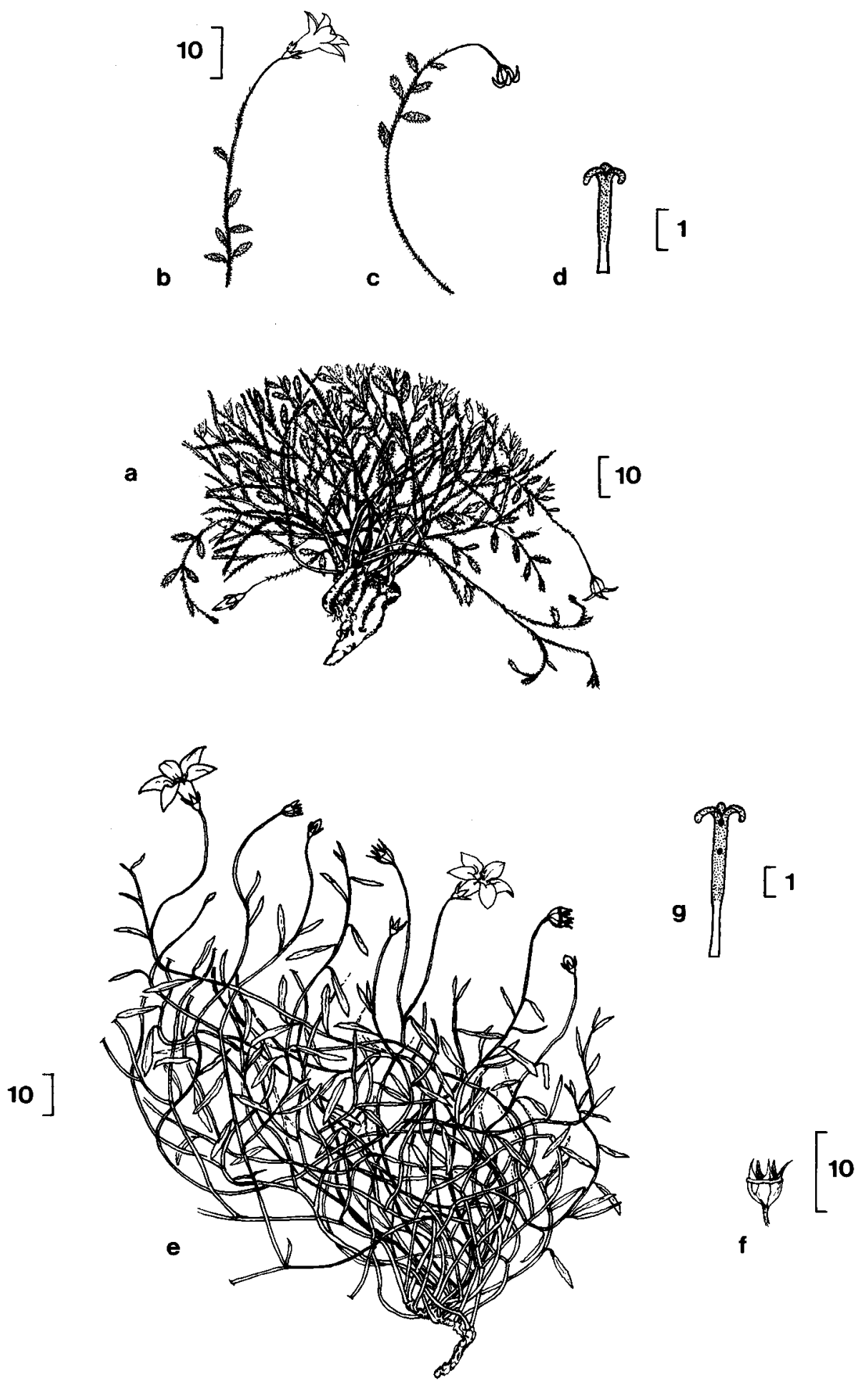

Figure 9. W. scopulicola: a, habit; b, flower; c, capsule; d, style. W. glabra: e, habit; f, capsule; $\mathbf{g}$, style. a-d from Coveny 4552; $\mathrm{e}-\mathrm{g}$ from Smith 55 . Scale bars in $\mathrm{mm}$. 
DistRIBUTION: Restricted to the McPherson Range on the Queensland/New South Wales border. Figure 24a.

HaвiтAт: Grows in crevices on rock outcrops. The rock type at the Mt Lindesay site is rhyolite.

CONSERVATION STATUS: A rare species with a very restricted distribution, coded 2RC- by Briggs \& Leigh (1988). The Mt Lindesay population is conserved in Mt Lindesay Flora Reserve and Mt Lindesay National Park. The species is also represented in Lamington National Park.

Notes: Characteristic features of W. scopulicola are its densely tufted habit; decumbent or pendent, much-branched, hirsute stems; irregularly opposite and alternate, elliptic, petiolate, hirsute leaves; solitary flowers on short pedicels; corolla-lobes $\geq 5 \mathrm{~mm}$ long; and hemispherical capsules.

The epithet refers to the species' rock-face habitat. It was devised by R. Carolin in the 1960 s in his unpublished notes on the species. Latin scopulus, cliff or crag,-cola, dweller. The epithet is a noun in apposition and would retain its ending unchanged irrespective of the gender of the generic name.

Other SPECIMENS ExAMINED: QueENSLAND: Moreton: McPherson Ra., Araucaria Lookout, 28 $14^{\prime}$ S, 15312' E, Telford 8212, June 1980 (CBG). QueENSLAND/NEW SOUTH WALEs: Moreton/North Coast: Sources of Logan and Tweed, Collins \& Taylor, 1895 (MEL 57399); Mt Lindesay, Everist 1120, June 1935 (BRI), White 12737, Mar 1944 (BRI), Dowling 107, Sep 1973 (BRI), Constable, May 1949 (NSW 66877), Constable, Nov 1952 (NSW 24347, SYD), Coveny 4552 \& Rodd, Sep 1972 (NSW), Smith 57, Dec 1973 (SYD).

\section{Wahlenbergia glabra P.J. Smith, sp. nov.}

Herba perennis, glabra. Caules numerosi, decumbentes vel pendentes, ramosissimi, 5-35 cm longi. Folia irregulariter opposita et alterna, anguste elliptica pro maxima parte, 3-27 mm longa, 0.5-4 mm lata, sessilia. Flores solitarii, pedicellis $1-5 \mathrm{~cm}$ longis. Sepala 5, erecta, 2-3.5 mm longa. Corolla campanulata, tubo albo, 3-6.5 mm longo, lobis 5, caeruleis, 5.5-9 mm longis. Capsula hemisphaerica, 2-4.5 mm longa.

Type: QueEnSLAND: Darling Downs/Moreton: near the summit of Mt Cordeaux, P.J. Smith 55, Dec 1973; holo NSW.

[W. species A, Jacobs \& Pickard (1981: 96)]

[W. species 1, Stanley \& Ross (1986: 475)]

[W. species 2, Briggs \& Leigh (1988: 28)]

Perennial herb with a thickened taproot, tufted, many-stemmed. Stems 5-35 cm long, decumbent or pendent, crowded, much-branched, glabrous. Leaves irregularly opposite and alternate, narrowly elliptic, becoming linear at top of stem, acute to subulate, sessile, 3-27 mm long, 0.5-4 mm wide, glabrous; margins flat, entire or with small, distant callus-teeth. Flowers solitary; pedicels 1-5 cm long, glabrous, without bracteoles. Hypanthium hemispherical, 0.5-2.5 mm long, glabrous. Sepals 5, erect, \pm narrowly triangular, 2-3.5 mm long, glabrous. Corolla deeply campanulate, blue on lobes, white on tube, puberulous inside at base, otherwise glabrous; tube $3-6.5 \mathrm{~mm}$ long, longer than the sepals; lobes 5, elliptic to ovate, acute, 5.5-9 mm long, $2.5-4 \mathrm{~mm}$ wide. Stamens 5; filaments white, 0.9-1.6 mm long, upper section filiform, lower section obtrullate, with extended shoulders, ciliate on upper margins; anthers 2-4 mm long. Ovary 3-locular. Style white, $4.5-7 \mathrm{~mm}$ long, 3-fid, indistinctly constricted $1 / 2$ to $2 / 3$ down from the stigmatic lobes, covered with pollen-presenting hairs above the constriction, $0-2$ glands below each stigmatic cleft; stigmatic lobes $0.5-1.3 \mathrm{~mm}$ long. 
Capsule hemispherical, 2-4.5 mm long, 2-4.5 mm wide, glabrous. Seeds c. $0.5 \mathrm{~mm}$ long. Figure $9 \mathrm{e}-\mathrm{g}$.

CHROMOSOME NUMBER: $n=9$ (Smith 55).

FLOWERING PERIOD: Throughout the year (records for Jan, May, June, Aug, Oct, Dec).

Distribution: Restricted to south-eastern Queensland and north-eastern New South Wales. The only known localities are in the McPherson Range and at Cunninghams Gap. Figure 24b.

НавітAт: Grows in crevices on rock outcrops. It grows on basalt at Mt Cordeaux, Mt Mitchell, Wilsons Peak and Morans Falls.

CONSERVATION STATUS: A rare species with a very restricted distribution, coded 2RC- by Briggs \& Leigh (1988). Populations are conserved in Main Range and Lamington National Parks.

Notes: Characteristic features of W. glabra are its densely tufted habit; decumbent or pendent, much-branched, glabrous stems; irregularly opposite and alternate, narrowly elliptic, glabrous leaves; solitary flowers on short pedicels; corollas with white tubes and blue lobes, the lobes $>5 \mathrm{~mm}$ long; and hemispherical capsules.

The epithet refers to the species' glabrous nature. Latin glaber, glabrous.

Other SPecimens Examined: QueEnsland: Darling Downs/Moreton: Mt Mitchell, Cunninghams Gap, Telford 1528, May 1970 (CBG, NSW); Mt Cordeaux, Phillips, June 1961 (CBG 018920), Briggs, June 1961 (NSW 67183). Moreton: Morans Falls, Lamington Natl Park, Smith 25, Dec 1943 (BRI), Telford 3382, Oct 1973 (CBG); head of Little Nerang R, McPherson Ra., White, Jan 1916 (BRI 159845). New South Wales: North Coast: Wilsons Peak, McPherson Ra., Whaite 279, Aug 1949 (NSW).

3. Wahlenbergia islensis P.J. Smith, sp. nov.

Herba perennis, glabra. Caules numerosi, ascendentes, ramosissimi, $7-50 \mathrm{~cm}$ longi. Folia alterna, linearia, infima interdum oblanceolata, 3-35 mm longa, 0.5-1.5 mm lata, sessilia. Inflorescentia cyma brevis vel flores solitarii, pedicellis $1-5 \mathrm{~cm}$ longis. Sepala 5, erecta vel effusa, 1-3 mm longa. Corolla campanulata, caerulea vel alba, tubo 1.5$3.5 \mathrm{~mm}$ longo, lobis 5, 3.5-5.5 mm longis. Capsula hemisphaerica, 1.5-3.5 mm longa.

TYPE: QuEENSLAND: Leichhardt: near Isla Gorge, P.J. Smith 132, 13 Sep 1974; holo NSW.

[W. species 1, Briggs \& Leigh (1988: 28)]

Perennial herb with a thickened taproot, tufted, many-stemmed. Stems 7-50 cm long, ascending, crowded, much-branched, glabrous. Leaves alternate, linear and subulate, sometimes lowermost oblanceolate and acute, sessile, 3-35 mm long, 0.5-1.5 mm wide, glabrous; margins flat, entire or with small, distant callus-teeth. Flowers solitary or in short cymes of 2-6 flowers confined to the upper third of the plant; pedicels 1$5 \mathrm{~cm}$ long, glabrous; bracteoles linear, 2-10 mm long, glabrous. Hypanthium hemispherical, 0.5-2 mm long, glabrous. Sepals 5, erect or spreading, narrowly triangular, $1.0-2.7 \mathrm{~mm}$ long, glabrous. Corolla deeply campanulate, blue to white, puberulous inside at base, otherwise glabrous; tube $1.5-3.5 \mathrm{~mm}$ long, longer than the sepals; lobes 5 , elliptic to ovate, acute, $3.5-5.5 \mathrm{~mm}$ long, $1.5-2.5 \mathrm{~mm}$ wide. Stamens 5; filaments white, 0.6-1.5 mm long, upper section filiform, lower section trullate, with or without extended shoulders, ciliate on upper margins; anthers 1.5-3.5 mm long. Ovary 3-locular. Style white, $2.5-5.5 \mathrm{~mm}$ long, 3-fid, unconstricted or indistinctly constricted $1 / 2$ to $2 / 3$ down from the stigmatic lobes, covered with pollen-presenting hairs above this point, 0-2 glands below each stigmatic cleft; stigmatic lobes $0.5-1.0 \mathrm{~mm}$ long. Capsule hemispherical, $1.5-3.5 \mathrm{~mm}$ long, $1.5-3 \mathrm{~mm}$ wide, glabrous. Seeds c. $0.5 \mathrm{~mm}$ long. Figure 10. 


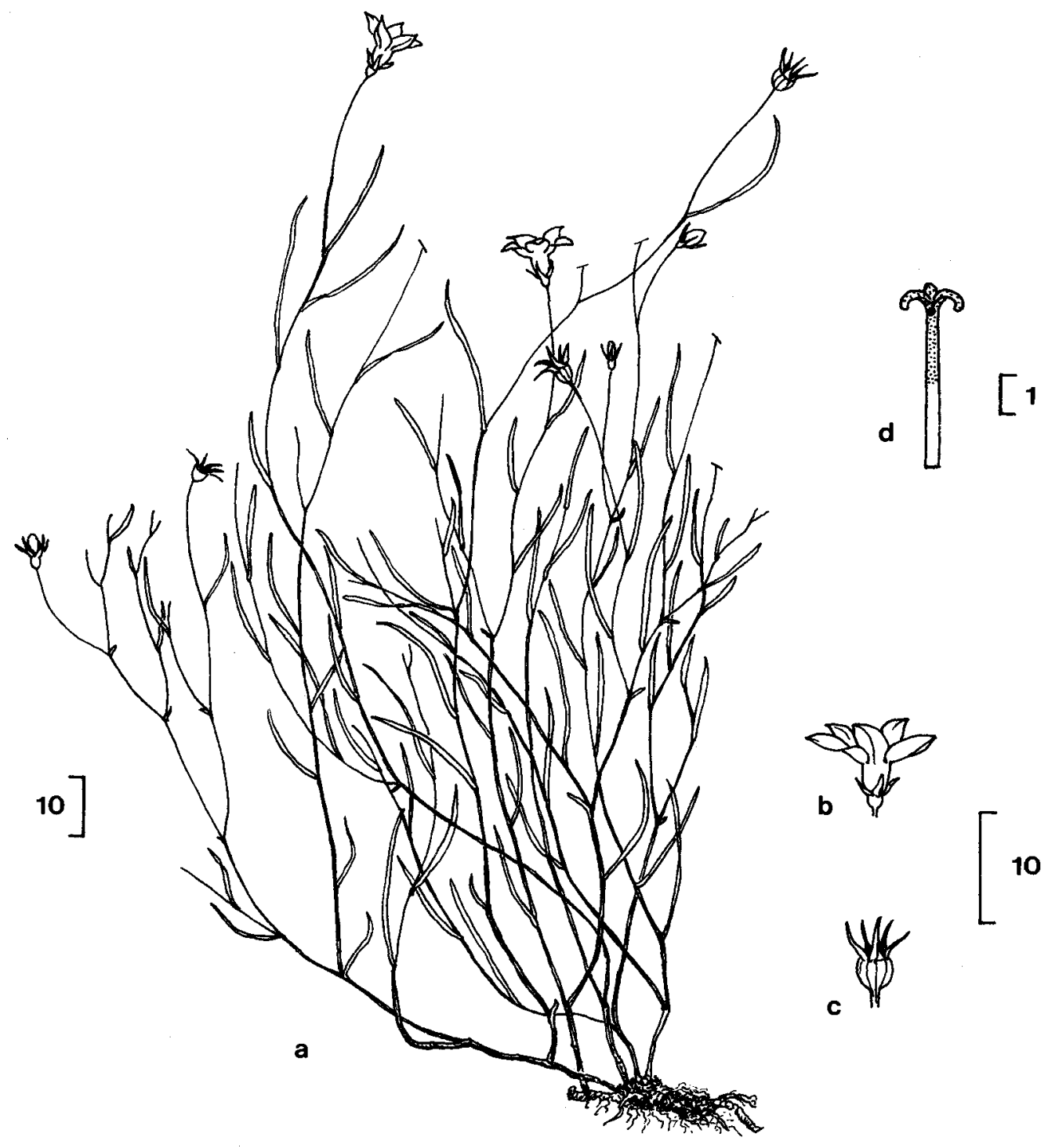

Figure 10. W. islensis: a, habit; b, flower; c, capsule; d, style. From Crisp 3110. Scale bars in mm. 
CHROMOSOME NUMBer: $n=9$ (Smith 132).

FLOWERING PERIOD: The few records available cover the period June-November. It is likely that the species flowers throughout the year.

DisTRIBUTION: Endemic to Queensland, where it is known from only three localities: Isla Gorge, Carnarvon Range and Chesterton Range. Figure 25a.

HabitAT: Grows in crevices on rock outcrops. It grows on sandstone at Isla Gorge and Chesterton Range.

CONSERVATION STATUS: A rare species with a restricted and disjunct distribution, coded 3RC- by Briggs \& Leigh (1988). Populations are conserved in Isla Gorge and Carnarvon National Parks.

Notes: Characteristic features of $W$. islensis are its densely tufted habit; ascending, much-branched, glabrous stems; alternate, linear, glabrous leaves; single- or fewflowered inflorescences confined to the upper third of the stem; corolla-lobes $\leq 5.5$ $\mathrm{mm}$ long; and hemispherical capsules.

The epithet refers to the species' occurrence at Isla Gorge.

Other SPecimens Examined: QueEnsLand: Leichhardt: Isla Gorge, c. 18 miles [30 km] SW of Theodore, Everist 8069, Sep 1968 (BRI). Maranoa: Maranoa R., W branch, c. $110 \mathrm{~km} \mathrm{NW}$ of Injune, The Tombs, Crisp 3110, June 1977 (CBG, BRI, NSW). Leichhardt/Maranoa: Wanderers Cave, Carnarvon Ra., Hockings, June 1962 (BRI 033730); Carnarvon Ra., Jones, Nov 1963 (BRI 051880).

\section{Wahlenbergia ceracea Loth.}

Lothian (1956: 166); Curtis (1963: 407); Burbidge \& Gray (1970: 346); Willis (1972: 627); Costin et al. (1979: 226).

TyPE: New SOUth Wales: Southern Tablelands: Kosciusko Plateau, on moist grassy slopes at Chalet, c. 5700 feet [1710 m], J.H. Willis, 5 Feb 1946; holo MEL 56931.

Perennial herb with a thickened taproot and spreading rhizomes ending in single stems. Stems 10-115 cm long, erect or ascending, usually unbranched or with only 12 branches, usually glabrous, sometimes lower stem sparsely hirsute; hairs to $1 \mathrm{~mm}$ long. Leaves alternate, obovate to narrowly elliptic, becoming lanceolate to linear on upper stem, obtuse to subulate, sessile, 5-50 mm long, 1-10 mm wide, usually glabrous, sometimes lower leaves sparsely hirsute; margins \pm flat, \pm entire. Flowers solitary or 2-3 per stem, rarely more; pedicels 5-40 cm long, glabrous; bracteoles lanceolate to linear, 3-19 $\mathrm{mm}$ long, glabrous. Hypanthium obconic, 2.5-7 $\mathrm{mm}$ long, glabrous. Sepals 5, \pm erect, narrowly triangular, 2.5-6 mm long, glabrous. Corolla shortly campanulate, usually blue, sometimes white, puberulous inside at base, otherwise glabrous; tube 3-7.5 $\mathrm{mm}$ long, equal to or longer than the sepals; lobes 5 , elliptic to ovate, acute, 10-23 mm long, 5.5-8.5 mm wide. Stamens 5; filaments white, 1.2-2.0 mm long, upper section filiform, lower section rhombic to obtrullate, with or without extended shoulders, ciliate on upper margins; anthers 4-7 mm long. Ovary 3-locular. Style white, 5.5-12 mm long, 3-fid, unconstricted or indistinctly constricted $1 / 2$ to $2 / 3$ down from the stigmatic lobes, covered with pollen-presenting hairs above this point, 0-2 glands below each stigmatic cleft; stigmatic lobes 1-3 mm long. Capsule obconic, 5-10 mm long, 3.5-5.5 mm wide, glabrous. Seeds c. $0.6 \mathrm{~mm}$ long. Figure 11a-b.

Chromosome number: $n=9$ (Carolin W25, W144, W145, 482).

FLOWERING PERIOD: November-May.

Distribution: High country of eastern New South Wales (north to near Tenterfield), 
eastern Victoria (west to Mt Buller) and northern Tasmania (south to Lake St Clair). Figure 25b.

HАвітAт: Grows in dense, low vegetation in moist sites at high montane to alpine levels. Typically found along watercourses, in bogs and other types of swamp vegetation, and in dense, moist grassland. Recorded at altitudes of $900-2200 \mathrm{~m}$ on the mainland, and down to about $600 \mathrm{~m}$ in Tasmania.

CONSERvation status: Not considered at risk.

Notes: Characteristic features of $W$. ceracea are its rhizomatous habit; unbranched or seldom-branched stems and inflorescence; alternate leaves with relatively flat margins; long pedicels; very large, blue, shortly campanulate corollas; 3-locular ovaries and 3-fid styles; and obconic capsules.

Selected Specimens (172 examined): New South Wales: Northern Tablelands: Spirabo Valley, 20 miles [33 km] SSE of Tenterfield, Constable, May 1961 (NSW 56095); Careys Peak, Barrington Tops, Carolin 482, Apr 1958 (SYD). Central Tablelands: Running Stream, $60 \mathrm{~km} \mathrm{~N}$ by road from Lithgow, Briggs 3478, Mar 1970 (NSW); upper Boyd R. [Kowmung R.], junction of Little Morong Ck, Carolin 3007, Apr 1961 (SYD). Southern Tablelands: 0.5 mile [1 km] NW of Big Badja Mill [45 km NE of Cooma], Briggs \& Rodd, Apr 1968 (NSW 125005); Betts Valley, Carolin W25, Jan 1956 (SYD); Island Bend, Carolin W144, Feb 1957 (SYD); Kiandra-Adaminaby, 10 miles [17 km], Carolin W145, Feb 1957 (SYD); Snowy River bridge below Seaman's Hut, Kosciusko area, Gray 6194 \& Totterdell, Feb 1968 (CANB, NSW). Australian CaptTal Territory: c. 33 km SW of Tharwa, Adams \& Hoogland 2691, Feb 1972 (CANB). VictoRiA: R: Mt Buffalo Natl Park, Short 1408, Jan 1982 (MEL, CBG). S: The Bluff, 7 miles [12 km] SE of Mt Buller, Muir 2774, Jan 1963 (MEL); 1 mile [2 km] N of Mt Wellington, Muir 3827, Jan 1966 (MEL). V: $6.4 \mathrm{~km}$ NW of Falls Creek, Beauglehole 22382, Jan 1967 (MEL); Native Cat Plain, Beauglehole \& Finck, Jan 1971 (MEL 56944). W: Upper Tambo Valley, Wakefield, Feb 1938 (MEL 56933); Dargo High Plains, Walsh 599, Jan 1982 (MEL). Z: Delegate River, Merrah, 1889 (MEL 56938). TASMANIA: Central Highlands: N of Lake St Clair, Curtis, Feb 1953 (HO 82579); Ben Lomond, Gulline, Feb 1950 (HO 8303). Western and South-western: Hatfield R. crossing, c. 33 km Rosebery-Wynyard, Canning 1987, Jan 1969 (CBG).

\section{Wahlenbergia gloriosa Loth.}

Lothian (1947a: 224), (1956: 165); Burbidge \& Gray (1970: 347); Willis (1972: 627); Costin et al. (1979: 227).

TYPE: Victoria: R: Mt Buffalo, P.R.H. St John, Mar 1930; lecto MEL 57090 (here chosen); isolecto MEL 57091.

[W. marginata var. grandiflora Tuyn (1960: 118), p.p., nom. nud.]

Perennial herb with a thickened taproot and spreading rhizomes ending in single stems. Stems 6-40 cm long, erect or ascending, usually unbranched or with only 1-2 branches, lower stem glabrous to hirsute, upper stem \pm glabrous; hairs to $1.5 \mathrm{~mm}$ long. Leaves often crowded, sometimes forming a basal rosette, usually irregularly alternate and opposite, sometimes all alternate, obovate to narrowly elliptic, becoming lanceolate to linear on upper stem, obtuse to subulate, sessile, 4-35 mm long, 1$15 \mathrm{~mm}$ wide, glabrous to hirsute; margins usually undulate, entire or with small, distant callus-teeth. Flowers solitary or 2-3 per stem, rarely more; pedicels $4-25 \mathrm{~cm}$ long, \pm glabrous; bracteoles lanceolate to linear, $3-18 \mathrm{~mm}$ long, \pm glabrous. Hypanthium elongated-obconic, 2.5-6.5 mm long, glabrous. Sepals usually 5, sometimes 4 or 6 , \pm erect, narrowly triangular, $2.5-7 \mathrm{~mm}$ long, glabrous. Corolla usually shortly campanulate; sometimes rotate, purple, entirely glabrous; tube $2.5-8.5 \mathrm{~mm}$ long, equal to or sometimes longer than the sepals; lobes usually 5 , sometimes 4 or 6 , elliptic, acute, 11-25 mm long, 6-12 mm wide. Stamens usually 5, sometimes 4 or 6; filaments white, 

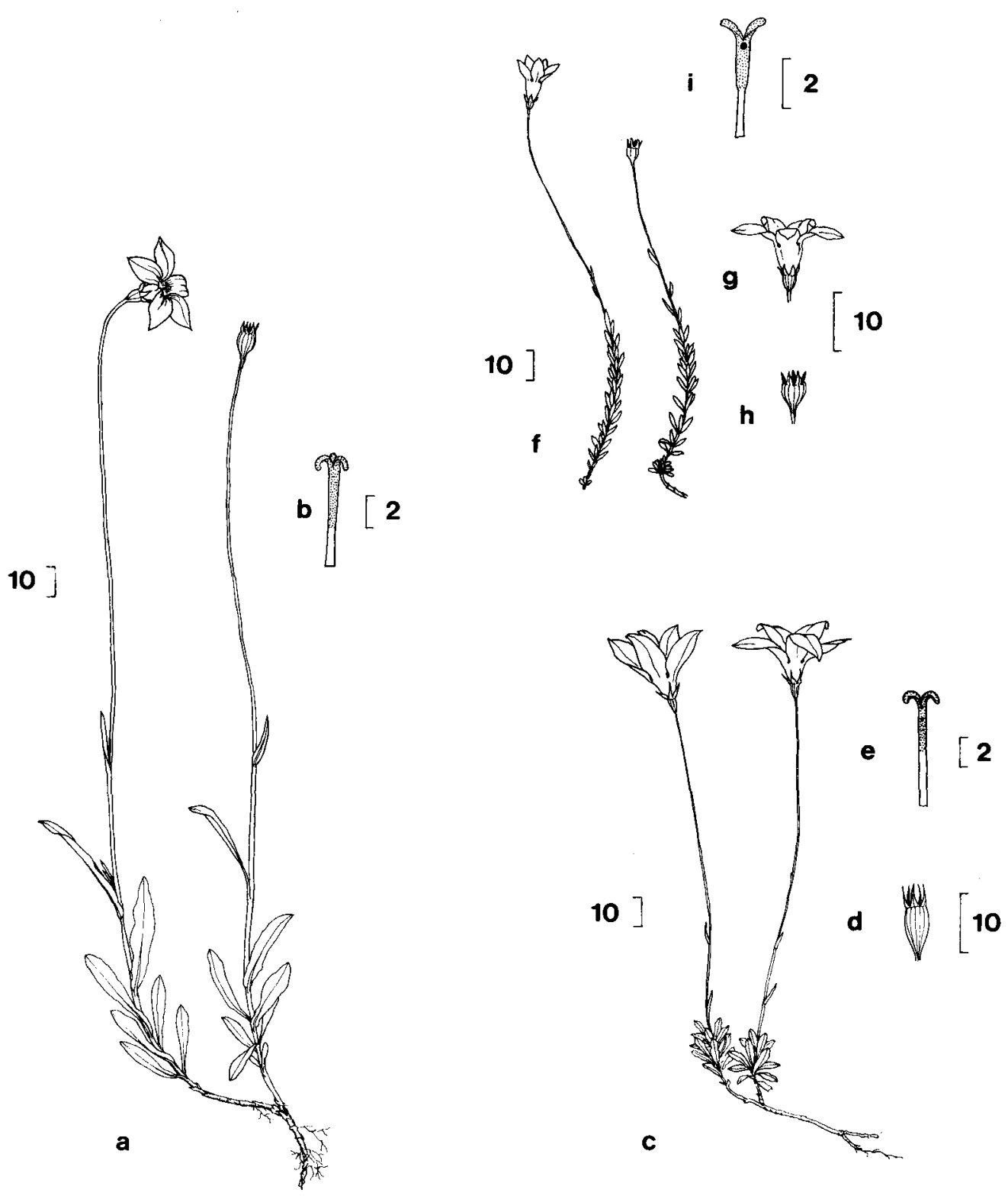

Figure 11 W. ceracea: $\mathbf{a}$, habit; $\mathbf{b}$, style. W. gloriosa: c, habit; d, capsule; e, style. W. densifolia: $\mathbf{f}$, habit; g, flower; h, capsule; i, style. a-b from Gray 6194; c-e from Hartley 13608; f-i from NSW 67060. Scale bars in $\mathrm{mm}$. 
1.9-2.7 mm long, upper section filiform, lower section trullate to obtrullate, with extended shoulders, ciliate on upper margins; anthers 4-7 mm long. Ovary usually 2locular, sometimes 3-locular. Style white, 6.5-13 mm long, usually 2-fid, sometimes 3fid, unconstricted or indistinctly constricted $1 / 2$ to $2 / 3$ down from the stigmatic lobes, covered with pollen-presenting hairs above this point, 1-2 glands below each stigmatic cleft; stigmatic lobes $1-3 \mathrm{~mm}$ long. Capsule usually elongated-obconic, sometimes obconic, $8-12 \mathrm{~mm}$ long, 3-5 mm wide, glabrous. Seeds c. $0.7 \mathrm{~mm}$ long. Figure 11c-e.

Chromosome NUMBer: $n=9$ (Carolin W26).

FLOWERING PERIOD: December-May.

Distribution: Restricted to the high country of south-eastern New South Wales, the Australian Capital Territory and eastern Victoria. Recorded from the Brindabella Range in the north-east to the Royston Range in the south-west. Figure 25a.

НАвгтАт: Grows mainly in eucalypt woodland and forest of the subalpine and high montane zones, but also extends to the alpine zone. Typically found in rocky sites. Recorded at altitudes of $1100-1800 \mathrm{~m}$.

CONSERVATION STATUS: The species has a fairly restricted distribution but is common there and is not considered at risk.

Notes: Characteristic features of W. gloriosa are its rhizomatous habit; unbranched or seldom-branched stems and inflorescence; leaves that typically have undulate margins and are partly opposite; long pedicels; very large, purple, shortly campanulate, entirely glabrous corollas; predominantly 2-locular ovaries and 2-fid styles; and elongated-obconic capsules.

Selected Specimens (146 examined): New South Wales: Southern Tablelands: Mt Gingera, Burbidge 1741, Mar 1947 (CANB); Guthega-Island Bend, 3 miles [5km] from Island Bend, Carolin W26, Jan 1956 (SYD); Andrews Lookout, Kosciusko Natl Park, Thompson 2831, Feb 1978 (NSW); Thredbo River-Hotel Kosciusko Rd, Johnson \& Constable, Jan 1951 (NSW 67069). Australian CAPITAL Territory: Mt Franklin, Singh 18295, Jan 1973 (CANB); Tinderry Mtns, Hartley 13608, Mar 1972 (CANB, NSW). VictoriA: R: Mt Buffalo, road to Mt McLeod, Todd 303, Feb 1975 (MEL). S: Mt Stirling, Melville $3231 \mathcal{E}$ Willis, Mar $1953(\mathrm{~K}, \mathrm{BRI}, \mathrm{AD}, \mathrm{PERTH}) ; 1$ mile [2 km] N of Mt Wellington, Muir 3826, Jan 1966 (MEL); Mt Torbreck, Willis, Mar 1943 (MEL 57179). V: The Razorback, Mt Feathertop-Mt Hotham, Craven 1539, Feb 1969 (CANB, MEL); Cobberas, W ascent, Wakefield 3012, Jan 1949 (MEL). W: Nunniong Plains, Beauglehole 36271 \& Finck, Jan 1971 (MEL); Mt Nugong, Melville 3121 E Wakefield, Jan 1953 (K, CANB, BRI, AD, PERTH). Z: Mt Tingaringy, Beauglehole 35749, Jan 1971 (MEL).

\section{Wahlenbergia gloriosa $\times$ W. stricta subsp. stricta}

Occasional specimens within both the New South Wales and Victorian distributions of $W$. gloriosa appear to represent hybrids with W. stricta subsp. stricta. These specimens show various mixtures of the characters of the two species. The leaves are more scattered and more consistently opposite than typical W. gloriosa; the flowers are usually in cymes or thyrsoids, although sometimes solitary; the large, shortly campanulate corollas are usually purple but sometimes blue; and the styles are sometimes 3-fid, sometimes 2-fid.

Specimens Examined: New South Wales: Southern Tablelands: Schlink Pass Rd (near Geehi-Island Bend Rd), Stead, Jan 1964 (NSW 64340); 0.5 km above Pilot Lookout, Kosciusko Natl Park, Thompson 1761, Jan 1973 (NSW). Victoria: V: near Carmodys Hut (Nariel to Gibbo Ck, N of Omeo), Ford, Jan 1959 (NSW 67018, CHR). W: Mt St Bernard, Williamson, Jan 1919 (NSW 66986). 


\section{Wahlenbergia densifolia Loth.}

Lothian (1956: 165); Willis (1972: 625).

Type: New South Wales: Southern Tablelands: Wragges Ridge, Kosciusko Plateau, c. 5000 feet $[1500 \mathrm{~m}]$, A.B. Costin, 18 Apr 1947; holo MEL 57075.

Perennial herb with a thickened taproot and spreading rhizomes ending in single stems. Stems $7-30 \mathrm{~cm}$ long, erect or ascending, usually unbranched or with only 1-2 branches, upper stem glabrous, lower stem \pm pubescent; most hairs $\leq 0.2 \mathrm{~mm}$ long, with scattered larger hairs to $0.5 \mathrm{~mm}$ long. Leaves \pm crowded, irregularly opposite, alternate and whorled, becoming alternate above, mostly narrowly oblong, with lowermost oblanceolate and uppermost lanceolate, mostly obtuse, sessile, 3-15 mm long, 0.5-2 mm wide, upper leaves glabrous, lower leaves glabrous on upper surface, \pm pubescent on lower surface; margins flat, entire or with small, distant callus-teeth. Flowers solitary or 2-3 per stem, rarely more; pedicels 3-12 cm long, glabrous; bracteoles lanceolate to linear, 1-9 mm long, glabrous. Hypanthium obconic, 1.5-3.5 mm long, glabrous. Sepals 5, \pm erect, triangular or narrowly triangular, $2-4.5 \mathrm{~mm}$ long, glabrous. Corolla deeply or shortly campanulate, blue to purplish-blue, entirely glabrous; tube 2.5-6.5 mm long, equal to or longer than the sepals; lobes 5, elliptic to obovate, acute to obtuse, 8-15 mm long, 3-7.5 mm wide. Stamens 5; filaments white, $8 \mathrm{~mm}$ long, upper section filiform, lower section oblong to obtrullate, with or without extended shoulders, ciliate on upper margins; anthers $2.5-4 \mathrm{~mm}$ long. Ovary usually 2-locular, sometimes 3-locular. Style white, $4-8 \mathrm{~mm}$ long, usually 2-fid, sometimes 3-fid, \pm distinctly constricted about halfway down from the stigmatic lobes, covered with pollen-presenting hairs above the constriction, 1 gland below each stigmatic cleft; stigmatic lobes 1-2 mm long. Capsule obconic, 3.5-8 mm long, 2.5-4 mm wide, glabrous. Seeds c. $0.5 \mathrm{~mm}$ long. Figure $11 \mathrm{f}-\mathrm{i}$.

Chromosome nUmber: $n=9$ (Carolin W148).

FLOWERING PERIOD: November-May.

DistriBution: Restricted to the high country of south-eastern New South Wales (Kosciusko National Park) and eastern Victoria (from Nunniong Plain west to Dargo High Plains). Figure 24a.

НавітAт: Grows in the subalpine zone in dense, moist grassland, sometimes under a sparse Eucalyptus pauciflora canopy. Recorded at altitudes of 1200-1550 m.

CONSERVATION STATUS: A rare species with a restricted distribution, coded 3RCa by Briggs \& Leigh (1988). The New South Wales populations are conserved in Kosciusko National Park.

NOTES: Characteristic features of $W$. densifolia are its rhizomatous habit; unbranched or seldom-branched stems and inflorescence; very short indumentum on lower stems and leaves; short, narrowly oblong, obtuse leaves in a typically crowded, irregular arrangement; large, entirely glabrous corollas; and predominantly 2-locular ovaries and 2-fid styles.

Selected SPecimens (30 examined): New SOUTh Wales: Southern Tablelands: Cooleman Plain, N of Tantangara Reservoir, Thompson 1987, Jan 1974 (NSW); Gurrangorambla Ck, Currango Plain, $\mathrm{N}$ of Tantangara Dam, Thompson 772, Jan 1971 (NSW); Kiandra-Adaminaby, 3 miles [5 km], Carolin W148, Feb 1957 (SYD); 2 km from Kiandra on road to Adaminaby, Smith 61, Mar 1974 (SYD); a few miles E of Kiandra, Thompson, Jan 1958 (NSW 67060); Happy Jacks Plain, headwaters of Happy Jacks R., 15 miles [25 km] S of Kiandra, Thompson, Jan 1958 (NSW 67059, CHR); Barneys Ck, part of the headwaters of Happy Jacks R., 16 miles [27 km] S of Kiandra, Thompson, Jan 1958 (NSW 67061); McKeahnies Ck valley (tributary of Happy Jacks R.), Mueller, Jan 1954 (NSW 67062); Long Plain, Kosciusko Natl Park, Jackson \& Canning, Jan 1979 (CBG 7901044); Mount 
Kosciusko, Hotel Kosciusko, Costin, May 1947 (NSW 67063); Thredbo Diggings, Kosciusko Natl Park, Thompson 2261, Jan 1975 (NSW). VICTORIA: V: 28 km NW of Omeo, Scarlett 81-26, Feb 1982 (MEL). W: Dargo High Plains, Willis, Jan 1946 (MEL 57077-57078); Nunniong Plain, about 18 miles [30 km] NNE of Ensay, Gippsland, Melville 3104 \& Wakefield, Jan 1953 (K, MEL, NSW, AD, BRI, PERTH); Nunniong Plain, Rogers, Jan 1967 (MEL 600034); Nunniong Plain, Beauglehole 36296 E Finck, Jan 1971 (MEL).

\section{Wahlenbergia gymnoclada Loth.}

Lothian (1947a: 227); Curtis (1963: 408); Carolin (1964: 240); Willis (1972: 627); Smith (1986: 1380).

TYPE: Victoria: E: Gorae West near Portland, A.C. Beauglehole, Nov 1943; lecto MEL 57198 (here chosen); isolecto MEL 57211, 57212, 628537.

W. billardierei Lothian (1947a: 226), as 'billardieri' $\equiv$ Campanula littoralis Labillardière (1805: 49). C. gracilis (var.) $\gamma$ littoralis (Labill.) R. Brown (1810: 561). W. gracilis (var.) $\gamma$ littoralis (Labill.) de Candolle (1830: 142), (1839: 433). W. gracilis f. littoralis (Labill.) Wawra (1883: 133). W. vinciflora var. littoralis (Labill.) N.E. Brown (1913: 355). W. marginata var. littoralis (Labill.) Hochreutiner (1934: 29). Non W. littoralis Schltr. \& von Brehmer (1915b: 127). TYPE: Australia: Nouvelle Hollande, Herb. Labillardière ex Herb. M.E. Moricand; lecto G (Carolin 1964: 237). Lothian (1947a: 227) selected a Robert Brown specimen as a neotype, but this must be rejected as Labillardière's material is extant. The names $W$. billardierei and $W$. gymnoclada were both published in the same paper, but the latter has become the name generally applied to the species and is retained here.

Perennial herb with a thickened taproot and spreading rhizomes ending in single stems. Stems 10-60 cm long, erect or ascending, usually unbranched or with only 12 branches, usually glabrous, sometimes a few scattered hairs on lower stem. Leaves opposite, becoming alternate above, linear, sometimes lowermost oblanceolate, obtuse to acute at base of stem, becoming subulate above, sessile, 5-50 mm long, 1-3.5 $\mathrm{mm}$ wide, usually glabrous, sometimes a few scattered hairs on lower leaves; margins flat, entire or with small, distant callus-teeth. Flowers solitary or 2-3 per stem, rarely more; pedicels 5-20 cm long, glabrous; bracteoles linear, 2-12 mm long, glabrous. Hypanthium obconic to elongated-obconic, 2.5-4 $\mathrm{mm}$ long, glabrous. Sepals 5, \pm erect, narrowly triangular, 2-6 mm long, glabrous. Corolla shortly campanulate, blue, puberulous inside at base, otherwise glabrous; tube 3-6 mm long, varying from shorter to longer than the sepals; lobes 5, elliptic, acute, 7-16 mm long, 4-7 mm wide. Stamens 5; filaments white, 1.4-3.0 mm long, upper section filiform, lower section trullate to obtrullate, with extended shoulders, ciliate on upper margins; anthers 3-5 mm long. Ovary 3-locular. Style white, 6-10.5 mm long, 3-fid, unconstricted or indistinctly constricted about halfway down from the stigmatic lobes, upper half covered with pollen-presenting hairs, 2 glands below each stigmatic cleft; stigmatic lobes 1-2 mm long. Capsule obconic to elongated-obconic, 5-9 $\mathrm{mm}$ long, 2-4 $\mathrm{mm}$ wide, glabrous. Seeds c. $0.7 \mathrm{~mm}$ long. Figure 12a-d.

Chromosome number: $n=9$ (Smith 171). H. Gulline (in Darlington \& Wylie 1955: 289) also reported a count of $n=9$, probably from Tasmania, but there is no voucher specimen to check the identification.

FLOWERING PERIOD: September-March, with one record in June.

Distribution: Widespread in Tasmania and from the far south-east of South Australia across southern Victoria to Mallacoota. Figure 24b. 


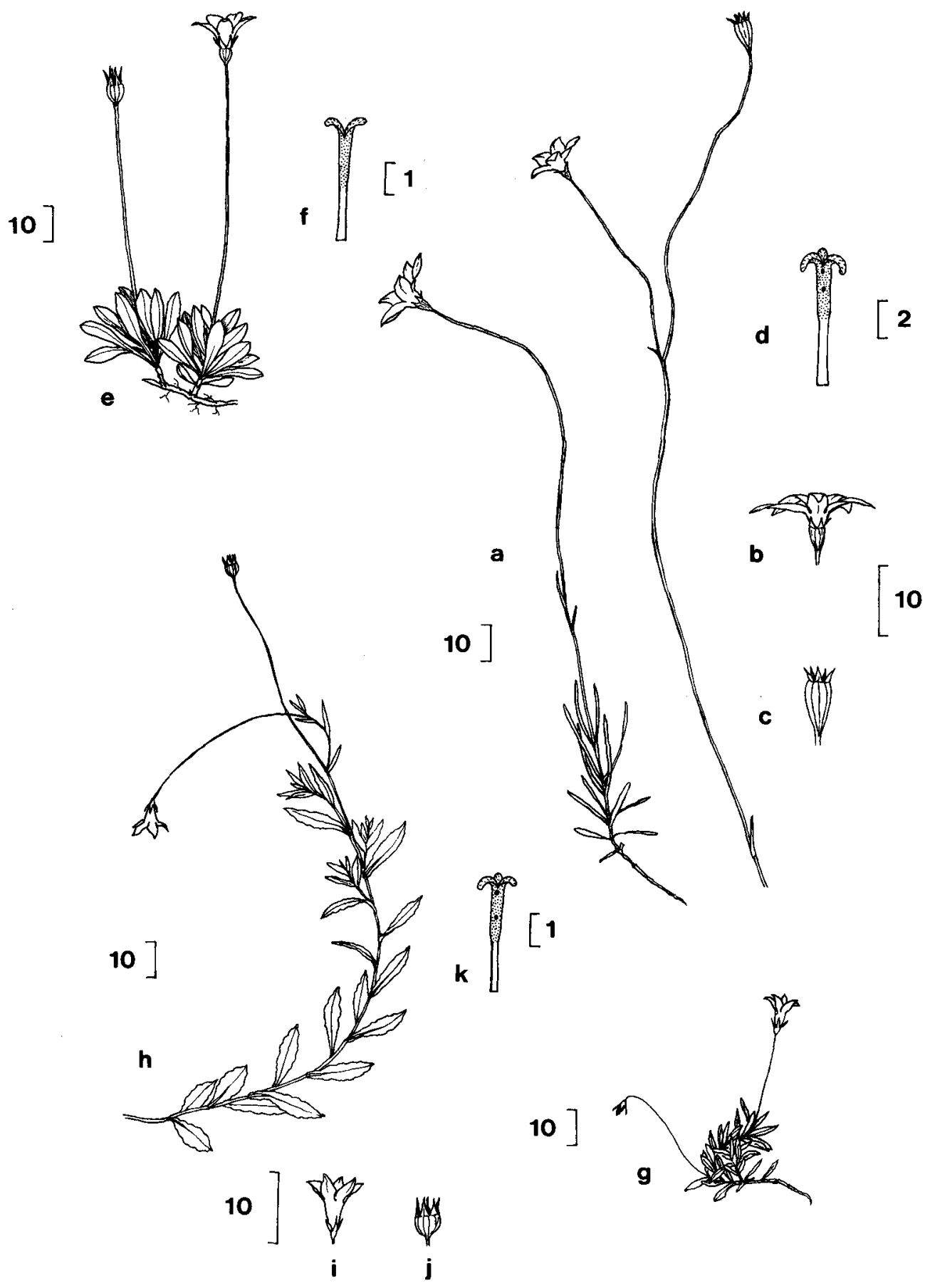

Figure 12. W. gymnoclada: a, habit; b, flower; c, capsule; d, style. W. saxicola: e, habit; f, style. W. insulae-howei: $\mathbf{g}, \mathbf{h}$, habit; i, flower; $\mathbf{j}$, capsule; $\mathbf{k}$, style. a,d from Melville 2521; b,c from CBG 022916; e,f from Rodway 5600; $g$ from NSW 120479; h-k from NSW 120478. Scale bars in mm. 
HAвітAт: Grows in eucalypt forest and woodland, coastal scrub and heath, cleared pastureland and swamp margins. Typically found in open sites, including disturbed sites. Recorded at altitudes from sea level to c. $750 \mathrm{~m}$.

CONSERVATION STATUS: Not considered at risk.

Notes: Characteristic features of W. gymnoclada are its rhizomatous habit; unbranched or seldom-branched stems and inflorescence; long, linear, opposite, glabrous lower leaves; long pedicels; and large, shortly campanulate corollas.

Selected Specimens (107 examined): South Australia: South-eastern: Marshs Swamp, Wilson 945, Nov 1968 (AD). VICTORIA: D: Wilkin, 12 miles [20 km] SW of Casterton, Aston 796, Oct 1960 (MEL, NSW, AD); Victoria Ra., Grampians, Beauglehole 6605, Nov 1964 (MEL, AD). E: $10 \mathrm{~km}$ SSW of Portland, Crisp 6855, Nov 1980 (CBG). K: Port Campbell Natl Park, Beauglehole 21400 \& Finck, Oct 1966 (MEL). N: Wandin, St john, Nov 1906 (MEL 57684). P: Arthurs Seat, Mornington Peninsula, Melville 2163 \& Wakefield, Nov 1952 (K, CANB, MEL, NSW, AD, BRI, PERTH). T: $19 \mathrm{~km}$ from Yarram on road to Traralgon, Smith 171, Jan 1975 (SYD). Z: Marlo, Hunter 23, Sep 1951 (MEL); Bastion Point, Mallacoota, Muir 1888, Nov 1960 (MEL, AD). TASMANIA: Central Highlands: Breona, Burbidge 3447, Jan 1949 (CANB, HO); Lake St Clair Natl Park, Eichler 16657, Jan 1960 (AD). Western and South-western: 1.5 miles [3 km] from Arthur R. mouth to Marrawah, Phillips, Nov 1965 (CBG 025269); Sandfly, Rodway 15, Jan 1931 (HO). North-eastern: 11 miles [18 $\mathrm{km}$ ] from Bridport towards Waterhouse, Phillips, Dec 1965 (CBG 022916, NSW); 4 miles [7 km] along Lake Leake turnoff from Tasman Hwy, Melville 2521, Dec 1952 (K, CANB, MEL, NSW, AD, BRI, PERTH); near Copping, Curtis, Nov 1959 (HO 53443).

\section{Wahlenbergia saxicola (R. Br.) A. DC.}

De Candolle (1830: 144); Hooker (1856: 239); Bentham (1869: 138); Rodway (1903: 107); N.E. Brown (1913: 354); Lothian (1947a: 232); Curtis (1963: 410); Curtis \& Stones (1969: 110); [misapplied by Bailey (1900: 922)]. Campanula saxicola R. Brown (1810: 561). Campanopsis saxicola (R. Br.) Kuntze (1891: 379).

TYPE: TASmania: Western and South-western: summit of Mt Wellington, R. Brown; lecto BM (Lothian 1947a: 232); isolecto K.

Streleskia montana Hooker (1847: 267). TYPE: TASMANIA: Western and South-western: summit of Mt Wellington, R.C. Gunn 1178; holo K.

Perennial herb with a thickened taproot and spreading rhizomes ending in single stems. Stems $2-15 \mathrm{~cm}$ long, erect or ascending, unbranched or with only 1-2 branches, glabrous or sometimes with a few scattered hairs. Leaves usually crowded into basal rosettes, sometimes more spread out (opposite, becoming alternate above), obovate to elliptic, becoming ovate above, obtuse to acute, sessile, 4-30 $\mathrm{mm}$ long, 2-10 $\mathrm{mm}$ wide, glabrous or sometimes with a few scattered hairs; margins \pm flat, with small, distant callus-teeth. Flowers solitary or 2-3 per stem; pedicels 2-10 cm long, glabrous; bracteoles located either within or above the basal rosette, ovate to lanceolate, 3-15 mm long, glabrous. Hypanthium hemispherical to obconic, $1.5-3.5 \mathrm{~mm}$ long, glabrous. Sepals usually 5, sometimes 3 or 4 , \pm erect, \pm narrowly triangular, $2-4 \mathrm{~mm}$ long, glabrous. Corolla deeply or shortly campanulate, blue, entirely glabrous; tube 2-4 mm long, similar in length to the sepals; lobes usually 5, sometimes 3 or 4 , elliptic, acute, 3-11 mm long, 1.5-4.5 mm wide. Stamens usually 5, sometimes 3 or 4; filaments white, 1.1-2.1 mm long, upper section filiform, lower section rhombic to obtrullate, without extended shoulders, ciliate on upper margins; anthers 1-2.5 mm long. Ovary usually 2-locular, sometimes 3-locular. Style white, 3.3-6 mm long, usually 2-fid, sometimes 3 -fid, unconstricted or indistinctly constricted $1 / 2$ to $2 / 3$ down from the stigmatic lobes, covered with pollen-presenting hairs above this point, $0-2$ glands below each stigmatic cleft; stigmatic lobes $0.5-1 \mathrm{~mm}$ long. Capsule hemispherical to obconic, 3-7 $\mathrm{mm}$ long, $2.5-5 \mathrm{~mm}$ wide, glabrous. Seeds c. $0.7 \mathrm{~mm}$ long. Figure $12 \mathrm{e}-\mathrm{f}$. 
CHromosome NUMBer: H. Gulline (in Darlington \& Wylie 1955: 289) reported a count of $n=36$, but there is no voucher specimen to check the identification.

FLOWERING PERIOD: December-April.

DistRIBUTION: Restricted to the high country of Tasmania. Figure 24a.

НАВітAT: Grows in the alpine and subalpine zones in herbfield, grassland, heath and woodland, usually amongst rocks.

CONSERVATION STATUS: The species has a fairly restricted distribution but is common there and is not considered at risk.

NoTEs: Characteristic features of $W$. saxicola are its rhizomatous habit; unbranched or seldom-branched stems and inflorescence; leaves crowded into basal rosettes; pedicels $\leq 10 \mathrm{~cm}$ long; medium-sized, entirely glabrous corollas with the tube similar in length to the sepals; and predominantly 2-locular ovaries and 2-fid styles.

Selected Specimens (47 examined): Tasmania: Central Highlands: Ironstone Plateau, Rodway, Dec 1899 (NSW 67147); Great Lake Rd, Curtis, Dec 1968 (HO 8350); Projection Bluff, Burns 279, Jan 1960 (HO); Drys Bluff marshes, Moscal 683, Feb 1981 (HO); Lake St Clair, Rodway, Dec 1917 (NSW 67145); Ben Lomond Natl Park, Short 1927, Feb 1983 (MEL); Mt Victoria, Rodway, Dec 1919 (HO 61209); S end of Lake Youl, Noble 28315, Feb 1979 (HO). Western and South-western: summit of Mt Bischoff, Atkinson, Jan 1923 (MEL 57238); Waratah, Burbury, 1893 (HO 90583); Windy Moor, SW of Mt Field East, Carolin 1605, Jan 1960 (SYD); Golden Stairs, Lake Dobson, Smith 419, Jan 1978 (HO); Big Bend, Mt Wellington, Orchard 5252, Jan 1981 (HO, MEL, AD); Mt Wellington, Rodway 5600, Feb 1903 (NSW).

\section{Wahlenbergia insulae-howei Loth.}

Lothian (1947a: 234); Rodd \& Pickard (1983: 271); Pickard (1983: 139).

TYPe: New SOuth Wales: Lord Howe Island: Lord Howe Island, W.W. Watts, Aug 1911; holo NSW 120477; iso MEL.

Lothian (1947a: 234) mistakenly stated that the collector of the type was W. Woolls (who died in the 1890s).

W. limenophylax Lothian (1947a: 233), as 'limnophylax' (Lothian 1947b: 366). TYPE: NeW South WALES: Lord Howe Island: North Hills, W.R.B. Oliver, 6 Nov 1913; holo NSW 120479; iso MEL 57724. The names W. limenophylax and $W$. insulae-howei were both published in the same paper, but the latter has become the name generally applied to the species and is retained here.

Perennial herb with a thickened taproot, tufted or with spreading rhizomes ending in single stems. Stems 4-25 cm long, erect or ascending, usually unbranched or with only 1-3 branches, glabrous or sometimes with a few scattered hairs. Leaves either crowded into basal rosettes or scattered along stem (alternate or with some leaves opposite), obovate to narrowly elliptic, obtuse to acute, sessile, 5-25 mm long, 2-7 $\mathrm{mm}$ wide, glabrous or sometimes with a few scattered hairs; margins \pm flat, with small, distant callus-teeth and also faintly serrate. Flowers solitary or 2-3 per stem, rarely more; pedicels $2-9 \mathrm{~cm}$ long, glabrous; bracteoles narrowly elliptic to lanceolate, 2-14 mm long, glabrous. Hypanthium hemispherical to shortly obconic, 1-2 mm long, glabrous. Sepals 5, erect, narrowly triangular, 2-3 mm long, glabrous. Corolla deeply campanulate, blue, puberulous inside at base, otherwise glabrous; tube 3-6 mm long, longer than the sepals; lobes 5, elliptic, acute, 3.5-6 mm long, $1.8-3.5 \mathrm{~mm}$ wide. Stamens 5; filaments white, 0.9-1.6 mm long, upper section filiform, lower section rhombic to obtrullate, with extended shoulders, ciliate on upper margins; anthers 
1.5-2.5 mm long. Ovary 3-locular. Style white, 4-5 mm long, 3-fid, \pm distinctly constricted about halfway down from the stigmatic lobes, covered with pollen-presenting hairs above the constriction, 2 glands below each stigmatic cleft; stigmatic lobes 0.5-1 mm long. Capsule hemispherical to shortly obconic, 2-4.5 mm long, 2-4 mm wide, glabrous. Seeds c. $0.6 \mathrm{~mm}$ long. Figure $12 \mathrm{~g}-\mathrm{k}$.

FLOWERING PERIOD: Throughout the year (records for Feb, Apr, Aug, Sep, Oct, Nov).

Distribution: Endemic in Lord Howe Island and nearby Balls Pyramid.

HABITAT: Typically grows in crevices on cliffs or in other rocky, exposed sites.

Conservation status: Classified as a rare species on Lord Howe Island by Pickard (1983). Subsequently listed as rare in Australia by Briggs \& Leigh (1988), coded 2RCa. It is well represented in the Lord Howe Island Permanent Park Preserve.

Notes: Characteristic features of $W$. insulae-howei are its unbranched or seldombranched stems and inflorescence; leaves often crowded into basal rosettes; pedicels $\leq 9 \mathrm{~cm}$ long; small corollas with the tube distinctly longer than the sepals; and hemispherical capsules.

Selected Specimens (23 examined): New South Wales: Lord Howe Island: Mt Lidgbird, E side, Nicholls, Apr 1944 (NSW 120478); Mt Lidgbird, SE side, Beauglehole 5636, Nov 1962 (CANB); Mt Eliza, Beauglehole 5637, Nov 1962 (CANB); Malabar, Beauglehole 5800, Sep 1963 (CANB); North Head, Beauglehole 6116, Sep 1963 (CANB); Balls Pyramid, Pettigrew, Feb 1969 (NSW 59744); Malabar Track, Crisp \& Telford 4456, Oct 1978 (CBG); Dawsons Point, Crisp E Telford 4494, Oct 1978 (CBG); Mt Gower, Crisp \& Telford 4528, Oct 1978 (CBG), Fullagar (MEL 57723); near Malabar Hill, Willis, Aug 1981 (MEL 628433).

\section{Wahlenbergia stricta $(R . B r$.$) Sweet$}

Sweet (1830: 593).

Perennial herb with a thickened taproot, tufted, few- to many-stemmed. Stems 10-90 $\mathrm{cm}$ long, erect or ascending, usually becoming much-branched, at least in the inflorescence, usually \pm hirsute, at least on lower stem, sometimes glabrous throughout; hairs to $2 \mathrm{~mm}$ long. Leaves and bracts usually opposite at base of stem, becoming alternate above, sometimes all opposite or all alternate or lower leaves in whorls of 3 , obovate to narrowly elliptic on lower stem, becoming lanceolate to linear above, obtuse to subulate, sessile, 5-70 mm long, 1-13 mm wide, usually at least the lower leaves \pm hirsute, sometimes all leaves glabrous; margins usually \pm undulate, sometimes flat, entire or with small, distant callus-teeth, sometimes faintly serrate. Flowers in thyrsoids of varying complexity covering the upper half or more of the plant; pedicels 2-19 cm long, glabrous to sparsely hirsute; bracteoles lanceolate to linear, 2$15 \mathrm{~mm}$ long, glabrous to sparsely hirsute. Hypanthium ellipsoid or globose, 2-4 mm long, glabrous to hirsute. Sepals usually 5, sometimes 4 or 6, erect or sometimes spreading, narrowly triangular, 3-16 mm long, glabrous to hirsute. Corolla deeply campanulate, usually blue, at least on the lobes, sometimes white or with a yellowish brown wash outside, puberulous inside at base and often sparsely hirsute along the veins; tube 4-11 mm long, shorter to longer than the sepals; lobes usually 5, sometimes 4 or 6 , elliptic to ovate, acute, 6-20 mm long, 2.5-12 mm wide. Stamens usually 5 , sometimes 4 or 6 ; filaments white, 1.3-2.5 mm long, upper section filiform, lower section rhombic to obtrullate, with extended shoulders, ciliate on upper margins; anthers 4-6 mm long. Ovary 3-locular. Style white, 5.5-13 $\mathrm{mm}$ long, 3-fid, unconstricted or sometimes indistinctly constricted $1 / 2$ to $2 / 3$ down from the stigmatic lobes, covered with pollen-presenting hairs above this point, 2-4 glands below each stigmatic cleft; stigmatic lobes 1-3 mm long. Capsule ellipsoid or globose, 3-10 $\mathrm{mm}$ long, $2.5-8 \mathrm{~mm}$ wide, glabrous to hirsute. Seeds c. $0.5 \mathrm{~mm}$ long. 
Notes: Characteristic features of $W$. stricta are its typically opposite, hirsute and undulate-margined lower leaves; long sepals; large, deeply campanulate corollas that are often sparsely hirsute along the veins; and ellipsoid or globose, often hirsute capsules.

\section{Key to subspecies}

1 Leaves mostly opposite (only the uppermost alternate), up to $13 \mathrm{~mm}$ wide; corolla usually all blue; style seldom exserted above corolla tube

a. subsp. stricta

$1^{*}$ Leaves mostly alternate (only the lowermost opposite), $\leq 6 \mathrm{~mm}$ wide; corolla usually blue inside, white outside; style usually exserted above corolla tube

b. subsp. alterna

10a. W. stricta subsp. stricta

W. stricta (R. Br.) Sweet (1830: 593); Carolin (1964: 235); Burbidge \& Gray (1970: 344); Willis (1972: 628); Cunningham et al. (1981: 627); Grieve \& Blackall (1982: 669); Beadle et al. (1982: 432); Beadle (1984: 771); Smith (1986: 1383); Stanley \& Ross (1986: 476); Wheeler (1987: 600). Campanula gracilis (var.) $\beta$ stricta $R$. Brown (1810: 561). W. gracilis (var.) $\beta$ stricta (R. Br.) de Candolle (1830: 142). C. gracilis f. stricta (R. Br.) Siebert \& Voss (1896: 572). C. erecta Sweet (1830: 326). W. bicolor Lothian (1947a: 230).

TYPE: An illustration with dissections, labelled 'C. gracilis Forst.', J.E. Smith (1805: t. 45); lecto (Carolin 1964: 236).

Brown (1810: 561) clearly based C. gracilis $\beta$ stricta primarily on Smith's plate (Carolin 1964: 236). He also referred to specimens from Port Jackson, but these are not conspecific with the plate (they are, in fact, specimens of $W$. luteola, q.v.). Sweet (1830: 593) subsequently supplied the name C. erecta for the species depicted in Smith's plate, then, in the same publication, transferred the species to Wahlenbergia as W. stricta, mistakenly attributing the epithet to Smith, who had never used it in a published form in this connection. More recently, Lothian (1947a: 230) supplied the name $W$. bicolor to replace $C$. gracilis $\beta$ stricta $\mathrm{R}$. Br., selecting as a 'lectotype' a specimen of $W$. luteola collected by Brown at Port Phillip. This 'lectotype' must be rejected as it was not chosen from the Port Jackson material referred to by Brown.

W. consimilis Lothian (1947a: 223); Curtis (1963: 408). TYPE: VICTORIA: R: Warby Ra., T.R.N. Lothian, 20 Sep 1942; lecto MEL 57010 (Carolin 1964: 236).

W. trichogyna Stearn (1951: 169); Black \& Robertson (1957: 810). W. marginata var. grandiflora subvar. trichogyna (Stearn) Tuyn (1960: 118). TYPE: New SOUTH WALES: Central Coast: Ingleburn, F.M. Hilton 448, Nov. 1943; holo MEL.

W. vinciflora f. eriocalyx Domin (1929: 638). TYPE: QUEENSLAND: Moreton: near the Logan R., K. Domin, Mar 1910; lecto PR Domin 8739 (Carolin 1964: 237), isolecto PR Domin 8738 .

[W. vinciflora (Vent.) Decaisne (1849: 41), as 'vincaeflora'; N.E. Brown (1913: 355); Domin (1929: 638); Black (1934: 183); Lothian (1947a: 220). C. vinciflora Ventenat (1803: 12), as 'vincaeflora', nom. illeg. (Stearn 1951: 169; Carolin 1964: 236) $\equiv$ C. gracilis Forster (1786: 84). C. gracilis (var.) $\alpha$ vinciflora (Vent.) R. Brown (1810: 561), as 'vincaeflora'. W. gracilis var. vinciflora (Vent.) Hooker (1856: 239), as 'vincaeflora'. The name $C$. vinciflora was superfluous when first published as it included, as a synonym, C. gracilis Forster $f$. Its type is therefore that of $W$. gracilis, although the epithet has generally been misapplied to $W$. stricta.] 


\section{[W. marginata var. grandiflora Tuyn (1960: 118), p.p., nom. nud.]}

Stems $10-90 \mathrm{~cm}$ long, usually \pm hirsute, at least on lower stem, sometimes glabrous throughout; hairs to $2 \mathrm{~mm}$ long. Leaves and bracts mostly opposite, becoming alternate above, sometimes all opposite or lower leaves in whorls of 3,5-70 mm long, 1-13 mm wide, usually at least the lower leaves \pm hirsute, sometimes all leaves glabrous. Pedicels 2-19 cm long, glabrous to sparsely hirsute; bracteoles 2-15 $\mathrm{mm}$ long, glabrous to sparsely hirsute. Hypanthium 1.5-5 mm long, glabrous to hirsute. Sepals usually 5 , sometimes 4 or 6, 3-16 mm long, glabrous to hirsute. Corolla usually blue, sometimes white on the outside or all white; tube 4-11 mm long; lobes usually 5 , sometimes 4 or 6, 6-20 mm long, 2.5-12 mm wide. Stamens usually 5, sometimes 4 or $6,1.6-2.5 \mathrm{~mm}$ long. Style 5.5-13 mm long, seldom exserted above the corolla tube; stigmatic lobes 1$3 \mathrm{~mm}$ long. Capsule 3-10 mm long, 2.5-8 mm wide, glabrous to hirsute. Figure 13a-c.

Chromosome Number: $n=9$ (Carolin 495, 2090, s.n. [Nowendoc], Smith 27, 35, 40, 82, 88, 90); $n=18$ (Carolin W19, W20A, W22, W24, W34, W132, W147, W154, Smith 50, 52, 74, 170). H. Gulline (in Darlington \& Wylie 1955: 289) also reported a count of $n=18$, probably from Tasmania, but there is no voucher specimen to check the identification.

FLOWERING PERIOD: Throughout the year, particularly September-February.

DistRibution: Widespread in south-eastern Australia, from the Carnarvon Range, Queensland, south to southern Tasmania and west to Eyre Peninsula, South Australia. Small, isolated populations in Western Australia (around Perth) and New Zealand appear to be introduced. Figure 26.

HABITAT: Grows in forest, woodland, scrub and grassland, typically amongst other herbs rather than in the open. Recorded over a wide altitudinal range, from sea level to about $1500 \mathrm{~m}$.

\section{Conservation status: Not considered at risk.}

Selfcted Specimens (1038 examined): Queensland: Darling Downs: Leslie Dam near Warwick, Smith 90, Dec 1973 (SYD); Applethorpe, Smith 82, Dec 1973 (SYD). Darling Downs/Burnett: Bunya Mts, White, Oct 1919 (BRI 159834). Leichhardt: Carnarvon Ck Gorge, 70 miles [117 km] NW of Injune, Johnson 2405, May 1952 (BRI, NSW). Moreton: Hollywell, Smith 27, May 1972 (SYD). Wide Bay: Cooloola, Harrold 152, Oct 1971 (BRI). New Soutr WALEs: North Coast: 8 km N of Hawks Nest on coast road, Smith 35, Oct 1972 (SYD). Central Coast: $72 \mathrm{~km}$ from Windsor on road to Putty, Smith 40, Nov 1972 (SYD); Colo Heights, Carolin 2090, Jan 1961 (SYD); 3 km from Wisemans Ferry on eastern road to St Albans, Smith 74, Nov 1973 (SYD). South Coast: South Crookhaven Head, Rodway 11763, Jan 1941 (NSW). Northern Tablelands: 58 km from Inverell on road to Glen Innes, Smith 88, Dec 1973 (SYD); Moonbi Ra., McKee (Carolin W132), Dec 1956 (SYD); Nowendoc, Carolin (SYD); Corker Pinch, Barrington Tops, Carolin 495, Apr 1958 (SYD). Central Tablelands: 2 miles [3 km] Pinnacle-Orange, Carolin W20A, Dec 1955 (SYD); Rocks Ck, Bathurst-Orange, Carolin W19, Dec 1955 (SYD); $60 \mathrm{~km}$ from Bathurst on road to Lithgow, Smith 52, Dec 1972 (SYD); $55 \mathrm{~km}$ from Bathurst on road to Lithgow, Smith 50, Dec 1972 (SYD); Goulburn-Mittagong 2 miles [3 km], Carolin W22, Jan 1956 (SYD). Southern Tablelands: Braidwood-Bungendore, Moore 2238, Dec 1952 (NSW); Kiandra-Adaminaby 10 miles [17 km], Carolin W147, Feb 1957 (SYD); Jindabyne-Kosciusko, Carolin W34, Jan 1956 (SYD); Mt Kosciusko Rd, Carolin W24, Jan 1956 (SYD); Brown Mt, facing sea, Carolin W154, Mar 1957 (SYD). North Western Slopes: 8 km NE of Coonabarabran, Briggs 3048, Nov 1969 (NSW). Central Western Slopes: Weddin Mt, $18 \mathrm{~km}$ W of Grenfell, Pullen 10.225, Dec 1975 (CANB, MEL, AD). South Western Slopes: Burrinjuck Rd, Moore 2177, Dec 1952 (NSW). North Western Plains: 21 miles [35 km] NE of Byrock, Thompson, Sep 1969 (NSW). Australian Capital Territory: Kowen Forest, 8 miles [13 km] E of Canberra, Evans 2575, Dec 1966 (CANB). New South Wales/Victoria: South Far Western Plains/A: junction of Darling R. and Murray R., Holding (MEL 57508). VICTORIA: A: 3 miles [5 km] N of Red Cliffs, Henshall 778, May 1968 (NT). C: Briggs Bluff, Grampians, Muir 2188, Sep 1961 (MEL). D: Victoria Valley, Grampians, Gullan, Nov 1976 (MEL 524103). E: 16.4 miles [27 km] N of Portland, Anderson 378, Jan 1969 (MEL, AD). G: Lower Loddon, Thorn, 1882 (MEL 57598). J: near Stawell, Banfield, Nov 1941 (MEL 57671). K: $14 \mathrm{~km}$ SSW of Winchelsea, 
Beauglehole 63689, Jan 1979 (MEL). M: Kangaroo Flat towards Bendigo, Tadgell, Oct 1934 (MEL 57049). N: Dandenong Ra., Muir 271, Nov 1957 (MEL). P: 11 km WSW of Anglesea, Beauglehole 63473, Jan 1979 (MEL). R: c. 5 miles [8 km] SE of Euroa, Muir 1384, Oct 1960 (MEL). S: Snobs Creek, Willis, Mar 1943 (MEL 57627). T: $13 \mathrm{~km}$ from Yarram on road to Traralgon, Smith 170, Jan 1975 (SYD). U: Pine Mt, c. 12 km from Walwa, Wheeler 194, Dec 1972 (CBG, PERTH). V: c. 50 km SSE of Tallangatta, Wilson, Dec 1961 (MEL 62862). W: Omeo-Mt Hotham, Rae, Jan 1940 (MEL 57363). Z: Gap Rd-Goongerah Ck, Beauglehole 34889, Nov 1970 (MEL). TASMANIA: Bass Strait Islands: Kings I., Neate (MEL 57345). Central Highlands: Ben Lomond Natl Park, Noble 28467, Mar 1979 (HO). Western and South-western: Kingston, Curtis, Nov 1941 (HO 53484). North-eastern: Picnic I., Buchanan 394, Jan 1981 (HO). SoutH Australia: Flinders Ranges: Alligator Gorge, Wilmington, Cooper, Oct 1954 (AD 97415263). Eyre Peninsula: Hundred of Hutchison, Section 99, Alcock C23, Nov 1964 (AD). Northern Lofty: Spring Gully Conservation Park, Yeatman 224, Oct 1980 (AD). Murray: Kinchina, Spooner 3842, Dec 1974 (AD). Yorke Peninsula: Hundred of Ramsay, Section 141, Blaylock 1032, Oct 1968 (AD). Southern Lofty: between Finniss and Goolwa, Carrick 2985, Feb 1971 (AD). South-eastern: Big Heath Natl Park, Alcock 3087, Nov 1969 (AD). Western Australia: Drummond: Bayswater near Perth, Nicholls, Dec 1947 (MEL). Dale: $70 \mathrm{~km}$ S of Perth on Albany Hwy, Fairall 1705, Nov 1965 (PERTH). New Zealand: Dunedin, Aug 1938 (K, MEL 57438).

10b. W. stricta subsp. alterna P.J. Smith, subsp. nov.

Ab subsp. stricta foliis alternis pro parte maxima, $\leq 6 \mathrm{~mm}$ latis, corolla extra vulgo alba, stylo tubo corollae vulgo longiore, differt.

TYPE: New South Wales: South Western Slopes: Northern slopes of The Rock, B.G. Briggs 2983, 25 Oct 1969; holo NSW.

[W. stricta subspecies A, Jacobs \& Pickard (1981: 96)]

Stems 15-85 cm long, hirsute below, glabrous above; hairs to $1.2 \mathrm{~mm}$ long. Leaves and bracts mostly alternate but usually a few opposite leaves at base of stem, 5-50 mm long, 1-6 mm wide, most leaves \pm hirsute, uppermost leaves glabrous. Pedicels $2-15$ $\mathrm{cm}$ long, glabrous; bracteoles 2-11 mm long, glabrous. Hypanthium $1.5-3 \mathrm{~mm}$ long, glabrous. Sepals 5, 3-9.5 mm long, glabrous. Corolla usually blue only on inner side of lobes, otherwise white, sometimes with a yellowish brown wash on the outside; tube 4-8.5 mm long; lobes 5, 6-13 mm long, 2.5-5.5 mm wide. Stamens 5, 1.3-1.8 mm long. Style 6-11 mm long, usually exserted above the corolla tube; stigmatic lobes 1-2 mm long. Capsule 3-6 mm long, 2.5-5 mm wide, glabrous. Figure 13d-f.

Chromosome number: $n=9$ (Smith 116); $n=18$ (Peacock 6110.15.1, Smith 115).

FLOWERING PERIOD: April-November.

Distribution: Replaces subsp. stricta in western New South Wales and south-western Queensland. Distributed from Cunnamulla in the north to The Rock in the south, and from Peak Hill in the east to Mootwingee in the west. Figure 26.

HaBitat: Grows in woodland or scrub, typically in hilly, rocky terrain. Also found in disturbed sites such as roadsides. In the Cocoparra Range, plants growing in eucalypt woodland were found to be diploid, while roadside plants were tetraploid.

CONSERVATION STATUS: Not considered at risk.

Notes: The chief character separating the two subspecies is the arrangement of the leaves, which are mostly opposite in subsp. stricta but only opposite at the very base of the stem in subsp. alterna. Other typical features of subsp. alterna are its relatively narrow leaves, corollas that are white outside, and styles that are exserted above the corolla-tube. Occasional specimens within the distribution of subsp. alterna have more pairs of opposite leaves and generally resemble subsp. stricta. 


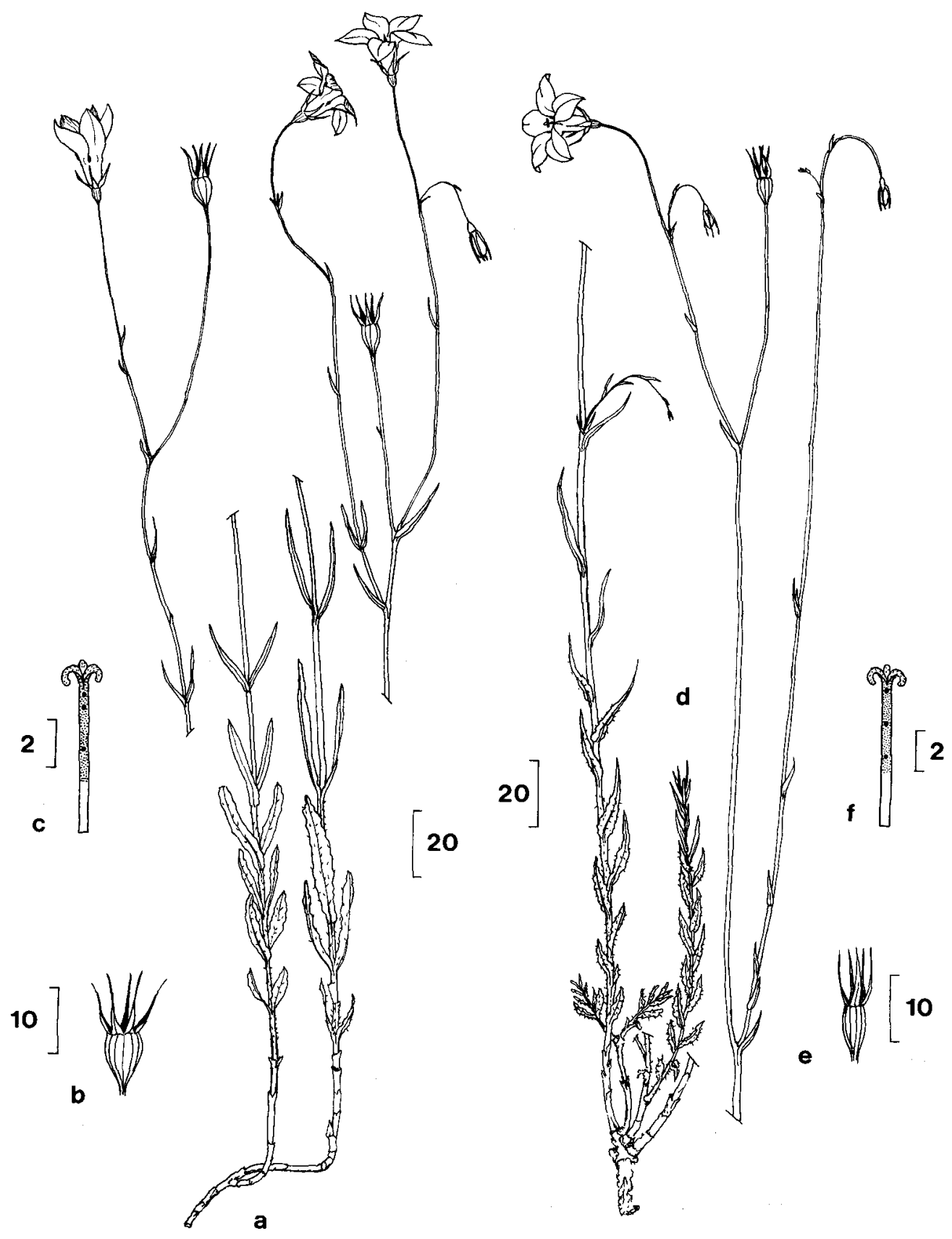

Figure 13. W. stricta subsp. stricta: $\mathbf{a}$, habit; $\mathbf{b}$, capsule; $\mathbf{c}$, style. W. stricta subsp. alterna: $\mathbf{d}$, habit; e, capsule; f, style. a-c from Moore 2238; d-f from Cunningham 858. Scale bars in mm. 
The epithet refers to the predominantly alternate arrangement of the leaves. Latin alternus, alternate.

SeleCted SPECimens (50 examined): Qufensland: Warrego: Gilruth Plains, E of Cunnamulla, Blake 14048, May 1939 (NSW). New SoUTH Wales: Central Western Slopes: Trewilga, Peak Hill, Peacock 6110.15.1, Oct 1961 (SYD); Mt Bunganbil, Ardlethan, Cunningham 5493 \& Milthorpe, Nov 1978 (NSW). South Western Slopes: The Rock Nature Reserve, $30 \mathrm{~km}$ SW of Wagga Wagga, Crisp 1824, Nov 1975 (CBG, SYD). North Western Plains: 'Lynwood', Cobar, Milthorpe \& Cunningham 5547, Nov 1978 (NSW); near 'Florida', Canbelego, Cunningham 858, Sep 1969 (NSW). South Western Plains: Naradham Ra., $30 \mathrm{~km} \mathrm{~N}$ of Rankins Springs toward Lake Cargelligo, Sikkes $462 \& \mathrm{Tel}$ ford, Oct 1972 (CBG, SYD); southern tip of Cocoparra Ra., Smith 115, 116, Apr 1974 (SYD); 11 miles [18 km] Roto-Mt Hope, Dunlop 1507, Sep 1969 (CBG). North Far Western Plains: Lake Nucha, Mootwingee, Milthorpe, Oct 1971 (NSW).

\section{Wahlenbergia luteola P.J. Smith}

Smith (1986: 1380).

TYPE: NeW SOUTH WALES: Northern Tablelands: $15 \mathrm{~km}$ from Glen Innes on road to Inverell, P.J. Smith 84, Dec 1973; holo NSW.

[W. bicolor Lothian (1947a: 230); Black \& Robertson (1957: 810) 三 Campanula gracilis (var.) $\beta$ stricta R. Brown (1810: 561). Lothian clearly intended $W$. bicolor to replace $C$. gracilis $\beta$ stricta $\mathrm{R}$. Br. (Carolin 1964: 236). Its type is therefore that of W. stricta (R. Br.) Sweet. Lothian's 'lectotype', a specimen of W. luteola collected by Brown at Port Phillip, must be rejected as it was not chosen from material referred to by Brown.]

Perennial herb with a thickened taproot, tufted, few- to many-stemmed. Stems 6-80 $\mathrm{cm}$ long, erect or ascending, usually becoming much-branched, at least in the inflorescence, usually glabrous, sometimes lower stem \pm hirsute; hairs to $1.0 \mathrm{~mm}$ long. Leaves and bracts opposite, becoming alternate above, sometimes all opposite or only lowermost opposite, linear, subulate, sometimes lowermost oblanceolate and acute to obtuse, sessile, 4-60 mm long, 1-4 mm wide, usually glabrous, sometimes lower leaves \pm hirsute; margins flat, entire or with small, distant callus-teeth. Flowers in thyrsoids of varying complexity covering the upper half or more of the plant; pedicels 2-18 cm long, glabrous; bracteoles linear, 2-16 mm long, glabrous. Hypanthium elongated-obconic, 3-7 mm long, glabrous. Sepals usually 5, sometimes $6, \pm$ erect, narrowly triangular, 3-8.5 mm long, glabrous. Corolla deeply or shortly campanulate, usually blue inside lobes, whitish elsewhere, often with a yellowish brown wash on the outside, sometimes entirely white or pink, puberulous inside at base, otherwise glabrous; tube 2-5 $\mathrm{mm}$ long, shorter than or equal in length to the sepals; lobes usually 5, sometimes 6, elliptic to ovate, acute, 6-14 $\mathrm{mm}$ long, 2.5-7.5 mm wide. Stamens usually 5, sometimes 6; filaments white, $1.3-2.0 \mathrm{~mm}$ long, upper section filiform, lower section trullate to obtrullate, with extended shoulders, ciliate on upper margins; anthers 3-5.5 mm long. Ovary 3-locular. Style white, $4.5-9 \mathrm{~mm}$ long, 3-fid, unconstricted or indistinctly constricted about halfway down from the stigmatic lobes, upper half covered with pollen-presenting hairs, 2-3 glands below each stigmatic cleft; stigmatic lobes 1-2 mm long. Capsule elongated-obconic, 5-12 mm long, 1.5-3.5 $\mathrm{mm}$ wide, glabrous. Seeds c. $0.6 \mathrm{~mm}$ long. Figure $14 \mathrm{a}-\mathrm{c}$.

Chromosome number: $n=9$ (Carolin 414, Smith 92, 104); $n=18$ (Carolin 478, 3006, Peacock 6110.3.1, Smith 37, 49, 72, 114).

FLOWERING PERIOD: Throughout the year.

DistRIBUtion: Widespread in south-eastern mainland Australia, from Tenterfield in the north-east to southern Eyre Peninsula in the south-west. Specimens were recorded 
as collected near Sydney early last century (see specimen list), but there have been no subsequent records from coastal districts in New South Wales. Figure 27a.

НАвітAт: Grows in woodland and grassland, typically in the open. Often found in disturbed sites such as roadsides.

CONSERVATION STATUS: Not considered at risk.

Notes: Characteristic features of $W$. luteola are its opposite, linear lower leaves; corollas that are whitish on the outside, often with a yellowish brown wash; relatively short corolla-tubes, shorter than or equal in length to the sepals; and elongatedobconic capsules.
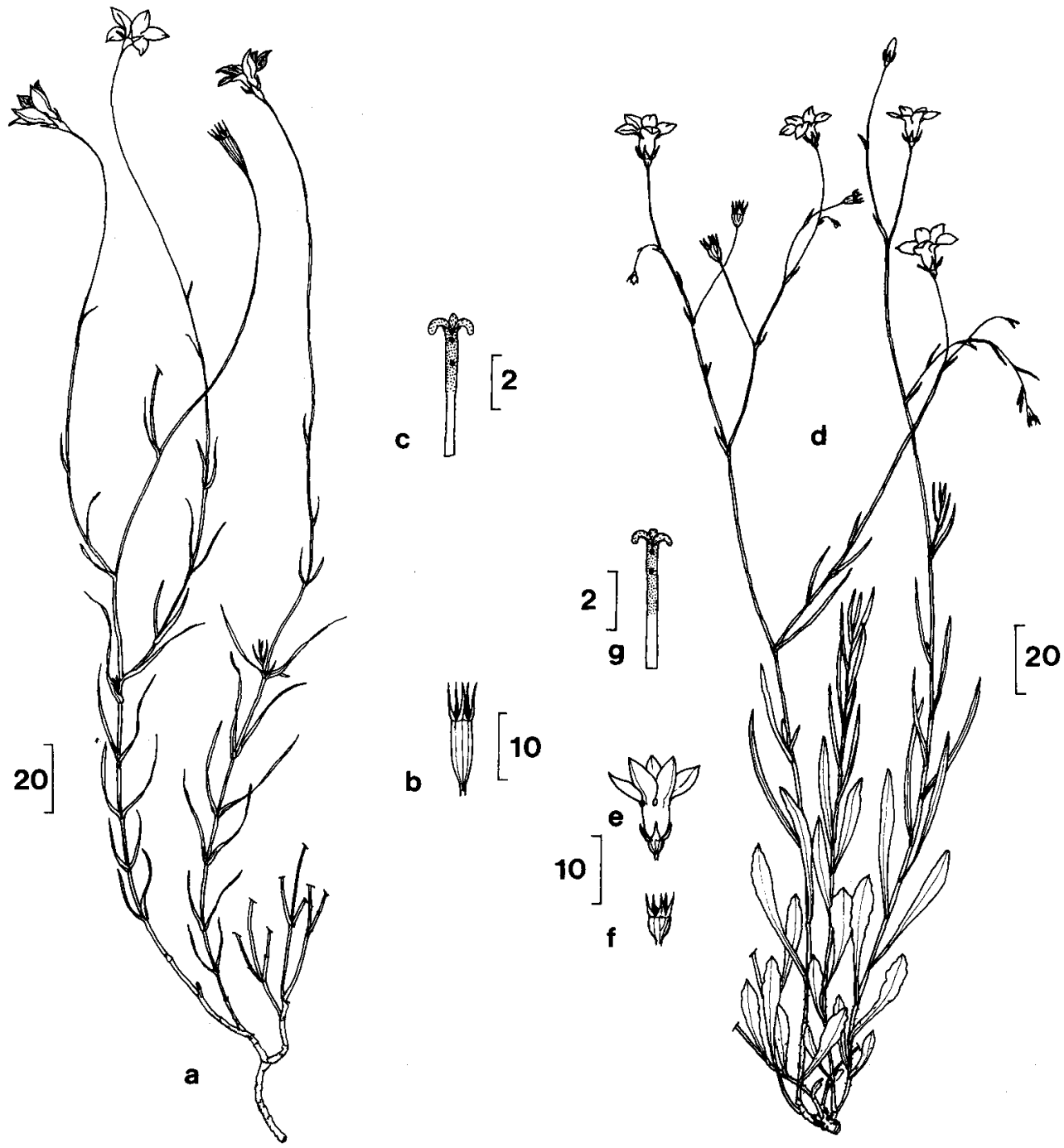

Figure 14. W. luteola: $\mathbf{a}$, habit; $\mathbf{b}$, capsule; $\mathbf{c}$, style. W. queenslandica: $\mathbf{d}$, habit; $\mathbf{e}$, flower; $\mathbf{f}$, capsule; g, style. a-c from NSW 66861; d-g from Crisp 2673. Scale bars in $\mathrm{mm}$. 
Selected Specimens (334 examined): New South Wales: Central Coast: Port Jackson district, including Cow Pastures, Brown, 1803 (CANB 279013). Northern Tablelands: $5 \mathrm{~km}$ from Glen Innes on road to Grafton, Smith 92, Dec 1973 (SYD); Glencoe, Carolin 414, Nov 1957 (SYD). Central Tablelands: $60 \mathrm{~km}$ from Bathurst on road to Lithgow, Smith 49, Dec 1972 (SYD); upper Coxs R., c. 6 miles [10 km] SW of Little Hartley, Carolin 3006, Apr 1961 (SYD); Tarana, Carolin 478, Apr 1958 (SYD); S of Hartley, Garden, Nov 1952 (NSW 66861). Southern Tablelands: $12 \mathrm{~km}$ from Jindabyne on road to Mt Kosciusko, Smith 104, Mar 1974 (SYD). North Western Slopes: $18 \mathrm{~km}$ from Coolah on road to Binnaway, Smith 37, Nov 1972 (SYD). Central Western Slopes: DubboWellington, 20 miles [33 km], Peacock 6110.3.1, Oct 1961 (SYD). South Western Slopes: Hume Hwy, 18 miles [30 km] W of Yass, Rodd $\mathcal{E}$ Coveny 2713, Dec 1969 (NSW). North Western Plains: $87 \mathrm{~km}$ from Nyngan on road to Cobar, Smith 72, Nov 1973 (SYD). South Western Plains: $15 \mathrm{~km}$ from Pulletop Faunal Reserve on road to Griffith, Smith 114, Apr 1974 (SYD). South Far Western Plains: between Euston and Gol Gol, Vickery, Oct 1949 (NSW 67043). Australian CaPITAL TeRRITORY: Canberra, Pryor, Nov 1937 (CANB 307697). VICTORIA: B: E of Pine Plains, Wyperfield Natl Park, Beauglehole 29316 \& Finck, Oct 1968 (MEL). C: Glenlee, Galbraith, Oct 1941 (MEL 57427). G: $5 \mathrm{~km}$ NW of Gama, Beauglehole 56898, Oct 1977 (MEL). H: Llanelly, Dale (Beauglehole 44006), Jan 1950 (MEL). J: 3 km NE of Nerrin Nerrin, Beauglehole 63096, Jan 1979 (MEL). L: 3 miles [5 km] NW of Strathmerton, Muir 4623, Oct 1967 (MEL). M: Bendigo, Robbins (Beauglehole 43999), Nov 1948 (MEL). N: $8 \mathrm{~km}$ SSW of Melton, Stuwe 544, Nov 1978 (MEL). P: Torquay, Jan 1943 (MEL 57471). R: 10 miles [17 km] W of Rutherglen, Muir 4609, Oct 1967 (MEL). S: 2 miles [3 km] W of Molesworth, Muir 3562, Oct 1964 (MEL). T: Garfield, Apr 1939 (MEL 57467). V: Hume Reservoir, Muir 2361, Oct 1961 (MEL). W: Reedy R. chasm, Nunniong Plateau, Beauglehole 41361, Feb 1973 (MEL). South Australia: Lake Eyre: Lake Callabonna, Black, May 1924 (AD 97606197). Flinders Ranges: Alligator Ck, Reichstein, Oct 1960 (AD 96139074). Eyre Peninsula: 10 km WSW of Whyalla, Chinnock 5000, Oct 1979 (AD). Northern Lofty: N Tothill Ra., Kraehenbuehl 2182, Oct 1967 (AD). Murray: near Monarto New Town, Spooner 6224, Nov 1978 (AD). Yorke Peninsula: Barunga Ra., Copley 755, Oct 1966 (AD). Southern Lofty: c. $1.6 \mathrm{~km} \mathrm{~N}$ of Nuriootpa, Kraehenbuehl 1733, Oct 1966 (AD). South-eastern: Bool Lagoon, Hunt 464, Nov 1961 (AD).

\section{Wahlenbergia communis Carolin}

Carolin (1964: 237); Burbidge \& Gray (1970: 344); Willis (1972: 626); Cunningham et al. (1981: 627); Carolin (1981: 350); Grieve \& Blackall (1982: 669); Beadle et al. (1982: 432); Beadle (1984: 771); Smith (1986: 1378); Stanley \& Ross (1986: 476).

Type: New South Wales: Northern Tablelands: Glen Innes, R.C. Carolin 2095, Jan 1961; holo NSW.

W. gracilis (var.) $\gamma$ capillaris (R. Br.) de Candolle (1830: 142), (1839: 433); Hooker (1852: 159), (1864: 170). Campanula gracilis (var.) $\gamma$ capillaris R. Brown (1810: 561). TYPE: NEW SOUTH WALES/QueENSLAND: Botany Bay, Bustard Bay, Bay of Inlets, J. Banks \& D.C. Solander; lecto BM (Carolin 1964: 238).

W. multicaulis var. dispar N.E. Brown (1913: 337). TyPe: Western Australia: Coolgardie: Fraser Ra., R. Helms, Elder Exploring Expedition, 29 Oct 1891; lecto K (Carolin 1964: 238).

[C. capillaris Loddiges (1828: 1406), nom. nud.]

Perennial herb with a thickened taproot, tufted, few- to many-stemmed. Stems 5-75 $\mathrm{cm}$ long, erect or ascending, usually becoming much-branched, at least in the inflorescence, glabrous or lower stem sparsely hirsute; hairs to $1.1 \mathrm{~mm}$ long. Leaves and bracts alternate, all linear or lowermost oblanceolate, acute to subulate, sessile, 4-80 mm long, 0.5-6 mm wide, glabrous or lower leaves sparsely hirsute; margins flat or sometimes undulate, entire or with small, distant callus-teeth. Flowers in thyrsoids of varying complexity covering the upper half or more of the plant; pedicels $2-10 \mathrm{~cm}$ long, glabrous; bracteoles linear, 2-16 mm long, glabrous. Hypanthium obconic to elongated-obconic, 2-5 mm long, glabrous. Sepals 5, erect, narrowly triangular, 2-6 
$\mathrm{mm}$ long, glabrous. Corolla deeply campanulate, usually blue, sometimes white on the outside or all white, puberulous inside at base and often sparsely hirsute along the veins; tube 4-9 $\mathrm{mm}$ long, usually longer than the sepals; lobes 5 , elliptic to ovate, acute, 6-13 mm long, 2.5-6 mm wide. Stamens 5; filaments white, 1.2-2.2 mm long, upper section filiform, lower section rhombic to obtrullate, with extended shoulders, ciliate on upper margins; anthers 3-6 mm long. Ovary 3-locular. Style white, 4.5-9.5 $\mathrm{mm}$ long, 3-fid, unconstricted or indistinctly constricted $1 / 2$ to $2 / 3$ down from the stigmatic lobes, covered with pollen-presenting hairs above this point, $2-5$ glands below each stigmatic cleft; stigmatic lobes 1-2 mm long. Capsule obconic to elongatedobconic, 4-9 mm long, 1.5-5 mm wide, glabrous. Seeds c. $0.5 \mathrm{~mm}$ long. Figure 15.

CHROMOSOME NUMBER: $n=8$ (Carolin W129, one chromosome very large); $n=9$ (Carolin W131, 2096, Smith 48A, 60, 82A); $\mathrm{n}=18$ (Carolin W83, W150, 6974, s.n. [Jerrys Plains], Smith 24, 26, 34, 40A, 42A, 44A, 45, 50A, 52A, 54A, 56, 58, 64, 72A, 86A, 102, 139, 146, 147, 149).

FLOWERING PERIOD: Throughout the year.

DistRIBUTION: Widespread in all mainland States but absent from Tasmania and not recorded north of $22^{\circ} \mathrm{S}$ in either Western Australia or the Northern Territory. The species also occurs in the New Guinea highlands. Figure 28.

HaвттAT: Occurs in a variety of vegetation types, typically in the open. It is often found in disturbed sites and is especially common along roadsides.

CONSERVATION STATUS: Not considered at risk.

NotEs: Characteristic features of $W$. communis are its alternate, predominantly linear leaves; large, deeply campanulate corollas with tubes usually longer than the sepals; and obconic to elongated-obconic capsules.

Selected SPECimens (810 examined): QueEnSLAND: Burke: 20 km N of Mt Isa, Schmid 211, May 1977 (BRI). Burnett: $3 \mathrm{~km}$ from Gayndah on road to Goomeri, Smith 42A, Nov 1972 (SYD); Goomeri, Smith 40A, Nov 1972 (SYD). Cook: 125 miles [208 km] N of Hughenden on the Lynd Rd, Carolin 8492, Apr 1974 (SYD). Darling Downs: Yuleba, Smith 149, Sep 1974 (SYD); 10 km from Warwick on road to Killarney, Smith 82A, Dec 1973 (SYD); $60 \mathrm{~km}$ from Goondiwindi on road to Moonie, Smith 50A, Nov 1972 (SYD). Gregory North: between Raven Downs and Muellers Ra., Birch (MEL 57851). Gregory South: Simpson Desert, Lake Muncoonie, Crisp 182, July 1974 (AD). Leichhardt: $57 \mathrm{~km}$ from Taroom on road to Wandoan, Smith 44A, Nov 1972 (SYD). Maranoa: 40 $\mathrm{km}$ E of St George, McDonald 270, Sep 1966 (BRI). Mitchell: $68 \mathrm{~km}$ from Barcaldine on road to Blackall, Smith 139, Sep 1974 (SYD). Moreton: Gatton, Watson, Oct 1930 (BRI 12932). North Kennedy: junction of Cooloomon and Little Cooloomon Cks, SW of Herberton, Whitehouse, May 1962 (BRI 037964). Port Curtis: Biloela, Smith 3503, Oct 1947 (BRI). South Kennedy: Springvale near Jericho, Scarth-Johnson 68b, Sep 1968 (BRI). Warrego: $79 \mathrm{~km}$ from Tambo on road to Augathella, Smith 147, Sep 1974 (SYD); Morven, Smith 146, Sep 1974 (SYD). Wide Bay: 7 km from Gin Gin on road to Gladstone, Smith 48A, Nov 1972 (SYD). New South WaLes: North Coast: 5 $\mathrm{km}$ from Warkworth on road to Broke, Smith 24, Apr 1972 (SYD). Central Coast: Glenbrook, Smith 58, Dec 1972 (SYD). South Coast: $18 \mathrm{~km}$ from Bega on road to Cobargo, Smith 102, Mar 1974 (SYD). Northern Tablelands: $8 \mathrm{~km}$ from Glen Innes on road to Grafton, Smith 86A, Dec 1973 (SYD); Moonbi Ra., McKee (Carolin W131), Dec 1956 (SYD). Central Tablelands: $17 \mathrm{~km}$ from Bathurst on road to Lithgow, Smith 56, Dec 1972 (SYD). Southern Tablelands: near Cooma church, Carolin W150, Mar 1957 (SYD). North Western Slopes: $27 \mathrm{~km}$ from Gunnedah on road to Breeza, Smith 60, June 1973 (SYD); Peel R., Tamworth, Carolin 2096, Jan 1961 (SYD); Nemingha, Smith 26, May 1972 (SYD); Quirindi-Werris Creek 5 miles [8 km], Carolin 6974, Oct 1968 (SYD). Central Western Slopes: $3 \mathrm{~km}$ from Cassilis on road to Merriwa, Smith 34, Nov 1972 (SYD); Jerrys Plains, Carolin (SYD). South Western Slopes: $13 \mathrm{~km}$ from Wagga Wagga on road to Temora, Smith 54A, Dec 1972 (SYD). North Western Plains: $8 \mathrm{~km}$ from Narrabri on road to Moree, Smith 45, Nov 1972 (SYD); 6 miles [10 km] ESE of Brewarrina on banks of Barwon R., Thompson, Sep 1969 (NSW 120488); Nyngan, Smith 64, Oct 1973 (SYD); 12 miles [20 km] W of Nyngan on 


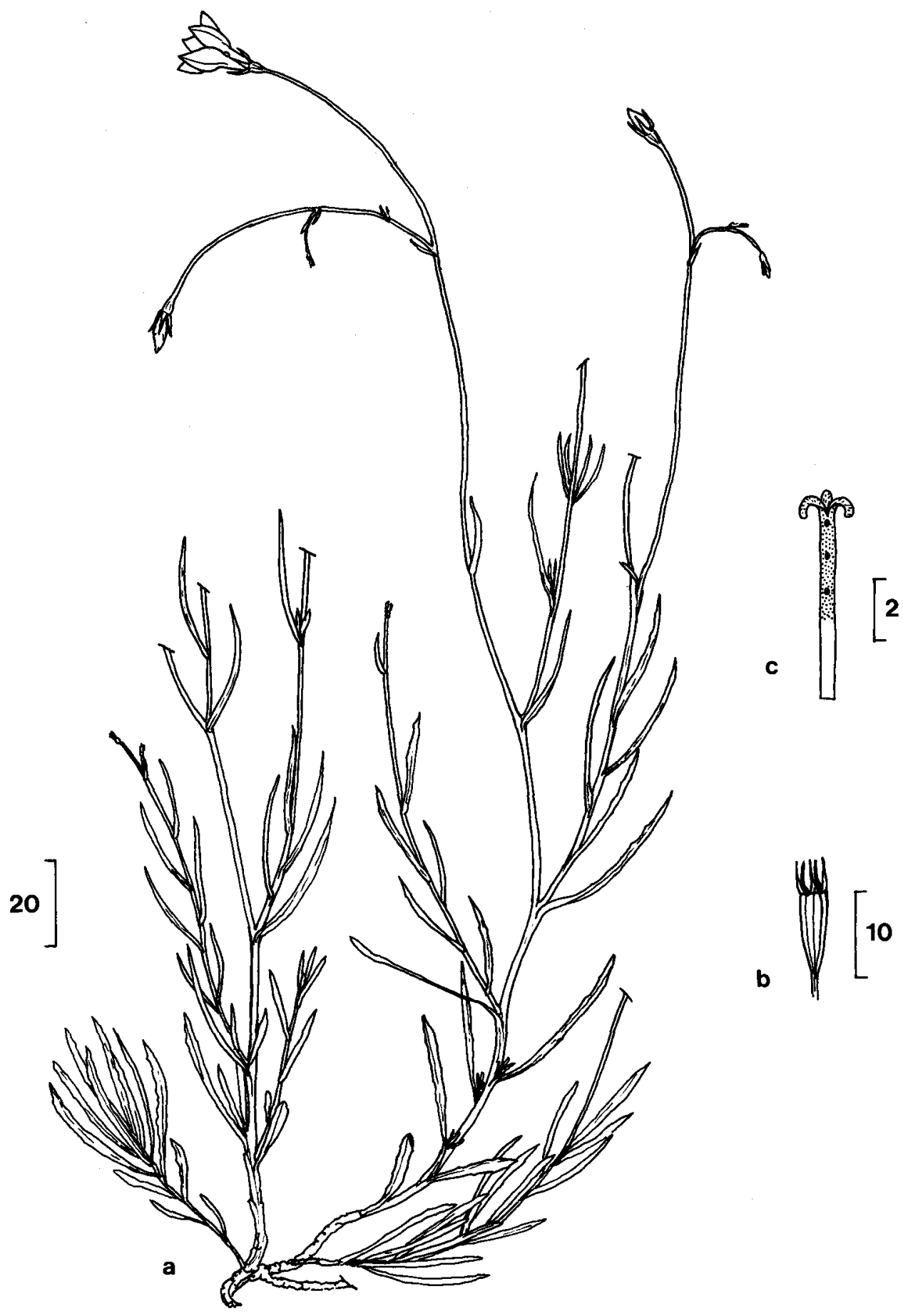

Figure 15. W. communis: a, habit; b, capsule; c, style. a from NSW 120488; b-c from Briggs 2685. Scale bars in $\mathrm{mm}$. 
Barrier Hwy, Briggs 2685, May 1969 (NSW); $63 \mathrm{~km}$ from Cobar on road to Wilcannia, Smith $72 A$, Nov 1973 (SYD). South Western Plains: $30 \mathrm{~km}$ from Rankins Springs on road to West Wyalong, Smith 52A, Dec 1972 (SYD). North Far Western Plains: Fowlers Gap-Tibooburra 5 miles [8 km], Carolin W83, June 1956 (SYD). South Far Western Plains: 28 miles [47 km] S of Broken Hill, Leigh W64, Oct 1966 (NSW). Region uncertain: Tamworth-Sydney, McKee (Carolin W129), Dec 1956 (SYD). Australian Capital Territory: Black Mt, Pullen 2062, Feb 1960 (CANB). Victoria: A: W edge of Raak Plain, Short 1240, Sep 1981 (MEL). B: $95 \mathrm{~km}$ SW of Mildura, Barnsley, Crisp $\mathcal{E}$ Cummings 100, Oct 1978 (CBG). C: Dimboola, Field Naturalist Reserve, Kraehenbuehl 38, Oct 1958 (AD). F: c. $25 \mathrm{~km}$ SSW of Robinvale, Beauglehole 56060, May 1977 (MEL). G: $5 \mathrm{~km}$ SW of Chinkapook, Beauglehole 55487, Apr 1977 (MEL). H: near Charlton, Ashby 2827, Mar 1969 (AD, CANB). L: Strathmerton, Aston 2215, Jan 1982 (MEL). M: Chewton towards Bendigo, Tadgell (MEL 57462). N: Ashburton, Melbourne, Muir 5636, Oct 1977 (MEL). T: Darnum Railway Station, Galbraith, May 1939 (MEL 57828). V: Ingeegoodbee R., Wakefield, May 1969 (MEL 1509988). W: c. $65 \mathrm{~km}$ N of Bairnsdale, Willis, Oct 1963 (MEL 628365). Z: upper Genoa R., Beauglehole 35018 \& Rogers, Nov 1970 (MEL). South Australia: North-western: Everard Ra., near Mareena Cave soak, Whibley 1221, Sep 1963 (AD). Lake Eyre: Terrapinne, Bates 293, May 1979 (AD). Nullarbor: Nullabor, $15 \mathrm{~km}$ S of Hwy, Toelken, Oct 1983 (AD 98415026). Gairdner-Torrens Basin: c. $15 \mathrm{~km}$ W of Yadlakina Well, Lothian 3406, Nov 1964 (AD). Flinders Ranges: Artipena Springs, Orchard 323, Apr 1968 (AD). Eastern: c. 6 km S of Milang Outstation on Koonamore Stn, Schodde 1122, May 1959 (AD). Eyre Peninsula: between Hesso and Tent Hill, Blaylock 471, June 1967 (AD). Northern Lofty: c. $15 \mathrm{~km}$ NNW of Port Wakefield, Kraehenbuehl 3510, Aug 1967 (AD). Murray: Brookfield Zoo Wombat Reserve, Blanchetown, Weber 3639, Oct 1973 (AD). Yorke Peninsula: Innes Natl Park, Alcock 4948, Oct 1974 (AD, SYD). Southern Lofty: Finniss, Cleland, Mar 1967 (AD 97207262). South-eastern: bank of Bool Lagoon, Hunt 1769, Jan 1964 (AD). Western Australia: Eucla: Eucla, Richards (MEL 57546). Carnarvon: Ningaloo Stn, Exmouth, Hutchinson 169, Aug 1971 (PERTH). Austin: Malcolm, Rodway 220, Sep 1907 (HO). Irwin: 42 km Northampton-Carnarvon, Telford 6710, Aug 1977 (CBG, SYD). Coolgardie: Fraser Ra., Aplin 1770, Sep 1962 (PERTH).

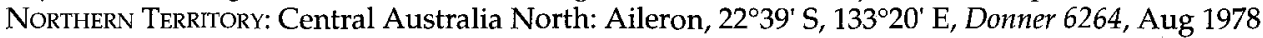
(AD, NSW). Central Australia South: 17 miles [28 km] W of Arltunga, Chippendale, Mar 1958 (NT 4078, MEL, NSW, AD, BRI, PERTH). NEW GuINEA: 20 miles [33 km] along Gemboge Rd from Kundiawa, Hewson 71, Aug 1965 (SYD).

\section{Wahlenbergia queenslandica Carolin ex P.J. Smith}

Smith (1986: 1381).

TYPE: QuEENSLAND: Leichhardt: Grosvenor near Clermont, R.C. Carolin 608, 19 Aug 1958; holo NSW; iso SYD.

[W. queenslandica Carolin ex Beadle (1984: 771), nom. nud.]

[W. species C, Carolin (1981: 350)]

[W. species C, Jacobs \& Pickard (1981: 96)]

[W. species 3, Stanley \& Ross (1986: 475)]

Perennial herb with a thickened taproot, tufted, few- to many-stemmed. Stems 10-90 $\mathrm{cm}$ long, erect or ascending, usually becoming much-branched, at least in the inflorescence, usually lower stem \pm hirsute, upper stem glabrous, sometimes glabrous throughout; hairs to $1.5 \mathrm{~mm}$ long. Leaves and bracts alternate or sometimes lowermost opposite, obovate to narrowly elliptic on lower stem, lanceolate to linear on upper stem, obtuse to subulate, sessile, 5-60 mm long, 1-9 mm wide, usually \pm hirsute on lower stem, glabrous on upper stem, sometimes all glabrous; margins flat or sometimes undulate, entire or with small, distant callus-teeth. Flowers in thyrsoids of varying complexity covering the upper half or more of the plant; pedicels $2-9 \mathrm{~cm}$ long, glabrous; bracteoles linear, 2-10 $\mathrm{mm}$ long, glabrous. Hypanthium hemispherical to shortly obconic, 1-3 mm long, glabrous. Sepals $5, \pm$ erect, \pm narrowly triangular, 1-4 
mm long, glabrous. Corolla deeply campanulate, blue, puberulous inside at base, otherwise glabrous; tube 4-6.5 mm long, longer than the sepals, often rather swollen in the middle; lobes 5, elliptic, acute, 6-10 $\mathrm{mm}$ long, 3-6 $\mathrm{mm}$ wide. Stamens 5; filaments white, 1.0-1.7 mm long, upper section filiform, lower section rhombic to obtrullate, with or without extended shoulders, ciliate on upper margins; anthers 3-5 mm long. Ovary 3-locular or sometimes 2-locular. Style white, 5-8.5 mm long, 3-fid or sometimes 2-fid, unconstricted or indistinctly constricted $1 / 2$ to $2 / 3$ down from the stigmatic lobes, covered with pollen-presenting hairs above this point, $2-4$ glands below each stigmatic cleft; stigmatic lobes $0.6-1.7 \mathrm{~mm}$ long. Capsule hemispherical to shortly obconic, $1.5-5 \mathrm{~mm}$ long, $1.5-3.5 \mathrm{~mm}$ wide, glabrous. Seeds c. $0.4 \mathrm{~mm}$ long. Figure $14 \mathrm{~d}-\mathrm{g}$.

Chromosome NUMBER: $n=9$ (Smith 38, 135); $n=18$ (Smith 39, 81, 85, 140).

FLOWERING PERIOD: Throughout the year.

Distribution: Widespread across Northern Australia, north of $30^{\circ} \mathrm{S}$. Figure 29.

НавітAт: Grows in a wide variety of mesic, semi-arid and arid vegetation types, typically in open sites, including disturbed sites.

CONSERVATION STATUS: Not considered at risk.

NOTES: Characteristic features of $W$. queenslandica are its alternate, non-linear, \pm hirsute lower leaves; large, deeply campanulate corollas with tubes longer than the sepals and often rather swollen in the middle; and hemispherical capsules.

Selected Specimens (140 examined): QueEnsLand: Burnett: Goomeri, Smith 38, Nov 1972 (SYD). Cook: c. 12 miles [20 km] SE of Mareeba, Pedley 2262, Apr 1967 (BRI). Darling Downs: 22 km from Miles on road to Wandoan, Smith 39, Nov 1972 (SYD); Applethorpe, Smith 85, Dec 1973 (SYD). Leichhardt: Isla Gorge, Everist 8081, Sep 1968 (BRI, CANB). Mitchell: Barcaldine, Smith 140, Sep 1974 (SYD). Moreton: Moreton I., $17 \mathrm{~km}$ SSE of Tangalooma, Durrington 1176, Oct 1973 (BRI). North Kennedy: $71 \mathrm{~km}$ from Pentland on road to Charters Towers, Smith 135, Sep 1974 (SYD). Port Curtis: Rockhampton, Boorman, Aug 1912 (NSW 66973). South Kennedy: 9 miles [15 $\mathrm{km}$ ] E of Yarrowmere Stn, Adams 1164, July 1964 (CANB, BRI, NSW, AD). Warrego: $20 \mathrm{~km} \mathrm{~W}$ of Charleville, Purdie 4850, June 1976 (BRI). Wide Bay: Moorlands, $25 \mathrm{~km}$ by road W of Bund aberg, Crisp 2673, May 1977 (CBG, NSW). NEW South WALES: Northern Tablelands: 57 km from Inverell on road to Glen Innes, Smith 81, Dec 1973 (SYD). North Western Plains: Lightning Ridge, Constable, May 1951 (NSW 66999). SOUTH Australia: North-western: Musgrave Ra., Cleland, Aug 1954 (AD 97218326). Lake Eyre: Karawinnie Waterhole, Donner 5205, Aug 1975 (AD). WESTERN Australia: Gardner: Dromaius Ck, Drysdale River Natl Park, George 13434, Aug 1975 (PERTH, CANB). Giles: S end of Dean Ra., Carolin 6091, Aug 1967 (SYD). Irwin: Murchison R. at Galena, Gardner 2595, Aug 1931 (PERTH). NORTHERN TERRITORY: Victoria River District: 39 miles [65 km] $S$ of Hookers Ck, Chippendale, July 1956 (NT 2266). Central Australia North: Anningie Stn, Central Mt Stuart, Mitchell 26, July 1974 (NT, DNA, CANB). Central Australia South: Ayers Rock, Wittmann, Aug 1964 (CANB 147353).

\section{Wahlenbergia graniticola Carolin}

Carolin (1964: 239); Burbidge \& Gray (1970: 346); Willis (1972: 626); Beadle et al. (1982: 432); Beadle (1984: 771); Stanley \& Ross (1986: 475); [misapplied by Grieve \& Blackall (1982: 669)].

Type: New South Wales: Central Tablelands: Lithgow to Mt Victoria 6 miles $[10 \mathrm{~km}$ from Lithgow on road to Mt Victoria], R.C. Carolin W106, Nov 1956; holo NSW.

Perennial herb with a thickened taproot, tufted, typically few-stemmed. Stems 7-95 cm long, erect or ascending, usually becoming much-branched, at least in the inflorescence, lower stem hirsute, upper stem \pm glabrous; hairs to $2.5 \mathrm{~mm}$ long. Leaves and bracts alternate or sometimes lowermost opposite, obovate to narrowly elliptic on lower 
stem, lanceolate to linear on upper stem, obtuse to subulate, sessile, 5-80 mm long, 1$15 \mathrm{~mm}$ wide, hirsute on lower stem, \pm glabrous on upper stem; margins flat or undulate, entire or with small, distant callus-teeth. Flowers in thyrsoids of varying complexity covering the upper half or more of the plant; pedicels $2-14 \mathrm{~cm}$ long, glabrous or sometimes sparsely hirsute; bracteoles linear or sometimes lanceolate, 2$9 \mathrm{~mm}$ long, glabrous or sometimes sparsely hirsute. Hypanthium obconic, 1.5-5 mm long, glabrous or sometimes \pm hirsute. Sepals 5, \pm erect, \pm narrowly triangular, 2-6 $\mathrm{mm}$ long, glabrous or sometimes \pm hirsute. Corolla shortly campanulate, usually blue, sometimes white, puberulous inside at base, otherwise glabrous; tube $2-6.5 \mathrm{~mm}$ long, varying from shorter to longer than the sepals; lobes 5, elliptic or sometimes obovate, acute or sometimes obtuse, 6-19 mm long, 3-10 mm wide. Stamens 5; filaments white, 1.0-2.3 mm long, upper section filiform, lower section rhombic to obtrullate, with or without extended shoulders, ciliate on upper margins; anthers 3-6 $\mathrm{mm}$ long. Ovary 3locular. Style white, 4.5-10 mm long, 3-fid, \pm distinctly constricted $1 / 3$ to $2 / 3$ down from the stigmatic lobes, covered with pollen-presenting hairs above the constriction, 1-3 glands below each stigmatic cleft; stigmatic lobes 1-2 $\mathrm{mm}$ long. Capsule obconic, 3-10 mm long, 1.5-4.5 mm wide, glabrous or sometimes \pm hirsute. Seeds c. $0.5 \mathrm{~mm}$ long. Figure 16.

Chromosome number: $n=9$ (Carolin 576, Smith 43, 53, 86, 141, 142, 145); $n=18$ (Carolin W115, Smith 47, 48, 54, 66, 68, 70, 87).

FLOWERING PERIOD: Throughout the year.

Distribution: South-eastern Queensland, eastern New South Wales and north-eastern Victoria, extending from Barcaldine in the north to Nunniong Plateau in the south. Figure 27b.

HaBITAT: Grows in forest, woodland, scrub and grassland. Tends to grow amongst other herbs rather than in the open, although it occurs in more open sites in the drier parts of its range.

CONSERVATION STATUS: Not considered at risk.

NoTES: Characteristic features of W. graniticola are its typically few-stemmed habit; alternate, hirsute, non-linear lower leaves; large, shortly campanulate corollas; styles with a distinct constriction about halfway down; and obconic capsules.

Selected Specimens (149 examined): QueEnSLand: Burnett: Gayndah, Hewson, Sep 1964 (SYD). Darling Downs: Yuleba, Smith 145, Sep 1974 (SYD); $28 \mathrm{~km}$ from Moonie on road to Goondiwindi, Smith 48, Nov 1972 (SYD); Leslie Dam near Warwick, Smith 87, Dec 1973 (SYD). Leichhardt: $50 \mathrm{~km}$ from Taroom on road to Theodore, Smith 47, Nov 1972 (SYD); $57 \mathrm{~km}$ from Taroom on road to Wandoan, Smith 43, Nov 1972 (SYD). Maranoa: 79 miles [132 km] SSE of Charleville, Williams 86, Sep 1968 (BRI). Mitchell: $9 \mathrm{~km}$ from Barcaldine on road to Blackall, Smith 141, Sep 1974 (SYD); Barcaldine, Smith 142, Sep 1974 (SYD). Moreton: St Lucia, Pedley, Aug 1955 (BRI 026580). Port Curtis: c. $100 \mathrm{~km} \mathrm{~N}$ of Bundaberg on coast, Smith 53, Nov 1972 (SYD). South Kennedy: Alpha, Carolin W229, Aug 1958 (SYD). Warrego: SW of Charleville, Everist 1429, Dec 1935 (BRI). Wide Bay: 10 miles [18 km] N of Gin Gin, Carolin 576, Aug 1958 (SYD). New SoutH WALEs: Northern Tablelands: $60 \mathrm{~km}$ from Inverell on road to Glen Innes, Smith 86, Dec 1973 (SYD). Central Tablelands: $60 \mathrm{~km}$ from Bathurst on road to Lithgow, Smith 54, Dec 1972 (SYD); Lithgow-Mt Victoria, Carolin W115, Sep 1956 (SYD). Southern Tablelands: Colinton, Costin, Oct 1948 (NSW 67080). North Western Slopes: 8 km from Coonabarabran to Bugaldi, Pulley 1101, Sep 1972 (CBG). Central Western Slopes: Coulsons Ck, foot of Liverpool Ra., N of Merriwa, Briggs 2196 $\mathcal{E}$ Rodd, Sep 1968 (NSW). South Western Slopes: Eastern Hill Stone Quarry near Saleyards, Albury, McBarron 1846, Aug 1948 (NSW). North Western Plains: $17 \mathrm{~km}$ from Bourke on road to Fords Bridge, Smith 66, Oct 1973 (SYD); $20 \mathrm{~km} \mathrm{~S}$ of Gongolgon on road to Coolabah, Smith 68, Oct 1973 (SYD); Nyngan, Smith 70, Oct 1973 (SYD). South Western Plains: Booberoi Railway Siding, $33^{\circ} 02^{\prime}$ S, $146^{\circ} 30^{\prime}$ E, Cunningham \& Milthorpe 4535, Oct 1973 (NSW). North Far Western 


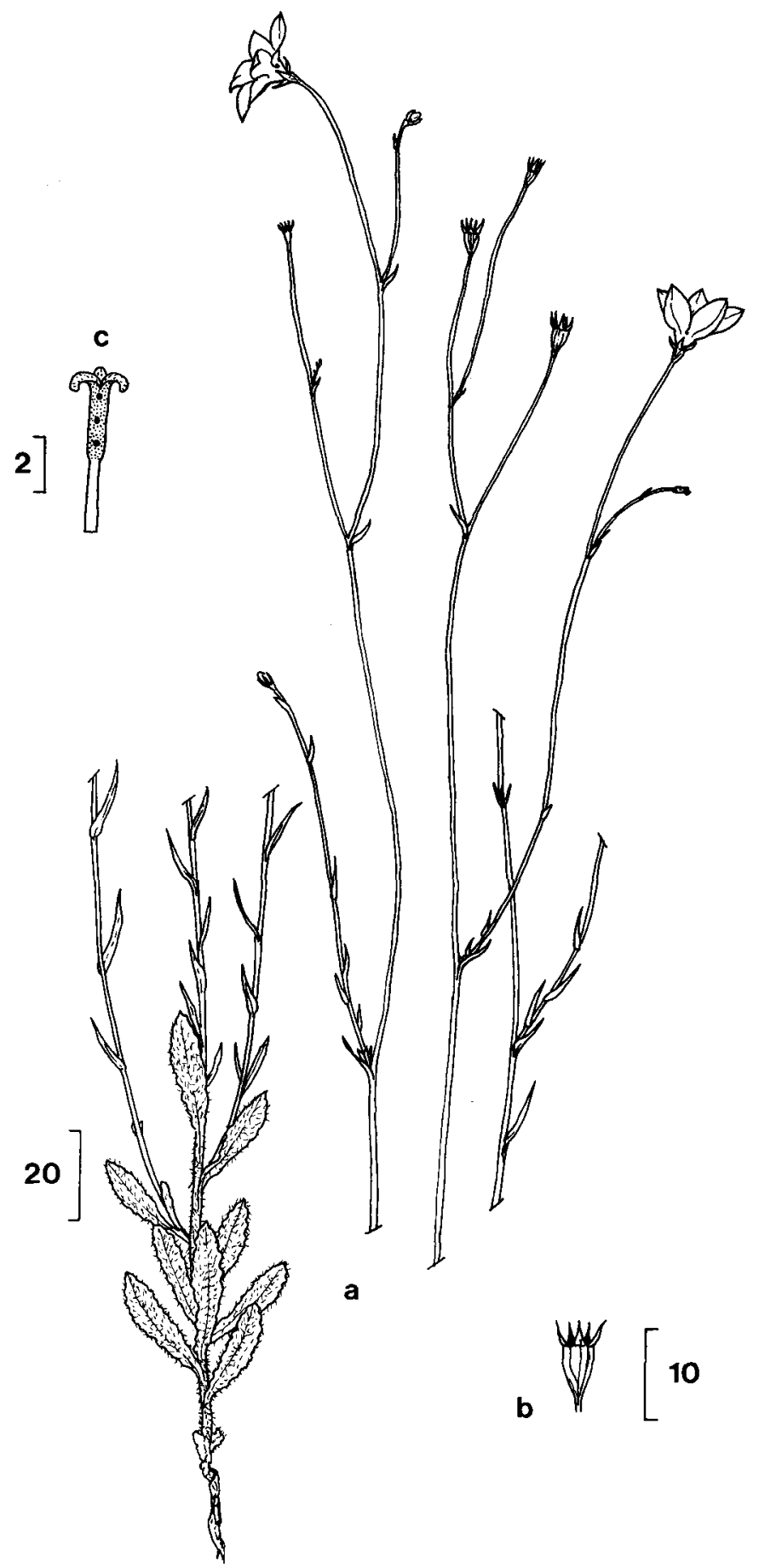

Figure 16. W. graniticola: a, habit; b, capsule; c, style. From Briggs 2196 . Scale bars in mm. 
Plains: Lake Woytchugga, Wilcannia, Smith 3225, July 1990 (NSW). Australian CAPItal TerriTORY: Kowen Pine Forest, $D^{\prime}$ Arnay 334, Nov 1964 (CANB). Victoria: R: c. $13 \mathrm{~km} \mathrm{~N}$ of Beechworth, Beauglehole 43826, Dec 1973 (MEL). V: 12 miles [20 km] W of Corryong, Muir 3703, Dec 1964 (MEL). W: Nunniong Plateau, Willis, Nov 1964 (MEL 628246). Z: Bidwell, upper Delegate R., Willis, Jan 1948 (MEL 628644).

\section{Wahlenbergia aridicola P.J. Smith}

Smith (1986: 1377).

Type: New South Wales: North Far Western Plains: Smithville-Hawker Gate, R.C. Carolin W91, 6 June 1956; holo NSW.

[W. species A, Carolin (1981: 350)]

Perennial herb with a thickened taproot, tufted, typically many-stemmed. Stems $12-$ $75 \mathrm{~cm}$ long, erect or ascending, usually becoming much-branched, at least in the inflorescence, glabrous or lower stem sparsely hirsute; hairs to $1.1 \mathrm{~mm}$ long. Leaves and bracts alternate, obovate to narrowly elliptic on lower stem, lanceolate to linear on upper stem, obtuse to subulate, sessile, 5-50 mm long, 1-6 mm wide, glabrous or lower leaves sparsely hirsute; margins flat or undulate, entire or with small, distant callus-teeth. Flowers in thyrsoids of varying complexity covering the upper half or more of the plant; pedicels $2-10 \mathrm{~cm}$ long, glabrous; bracteoles linear, 2-7 mm long, glabrous. Hypanthium hemispherical to obconic, 1.5-2.5 mm long, glabrous. Sepals 5, \pm erect, \pm narrowly triangular, $1.5-4 \mathrm{~mm}$ long, glabrous. Corolla shortly campanulate, blue, puberulous inside at base, otherwise glabrous; tube $2-3 \mathrm{~mm}$ long, varying from shorter to longer than the sepals; lobes 5 , elliptic or sometimes obovate, acute, 5-8 $\mathrm{mm}$ long, 3-3.5 mm wide. Stamens 5; filaments white, 0.9-1.7 $\mathrm{mm}$ long, upper section filiform, lower section rhombic to obtrullate, with extended shoulders, ciliate on upper margins; anthers 2-4 mm long. Ovary 3-locular. Style white, 4-6 mm long, 3-fid, \pm distinctly constricted $1 / 3$ to $2 / 3$ down from the stigmatic lobes, covered with pollenpresenting hairs above the constriction, $2-4$ glands below each stigmatic cleft, the uppermost gland sometimes elongated; stigmatic lobes $0.5-1 \mathrm{~mm}$ long. Capsule hemispherical to obconic, $2.5-5 \mathrm{~mm}$ long, $1.5-2.5 \mathrm{~mm}$ wide, glabrous. Seeds c. $0.5 \mathrm{~mm}$ long. Figure 17a-d.

Chromosome number: $n=9$ (Smith 77); $n=18$ (Carolin W94, Smith 75).

FLOWERING PERIOD: Throughout the year (records for Jan, May, June, Aug, Sep, Nov, Dec).

Distribution: Arid regions of eastern South Australia and western New South Wales. Figure 27b.

HABITAT: Recorded growing on dune swales and beside watercourses.

CONSERVATION STATUS: An uncommon species with a fairly restricted distribution. Included by Pressey et al. (1990) in a list of plant species with restricted distributions in the Western Division of New South Wales.

Notes: $W$. aridicola is closest to $W$. graniticola, differing in its typically many-stemmed habit; glabrous or only sparsely hirsute stems and leaves; generally smaller flowers; and generally shorter capsules. Some recent specimens (e.g. W. graniticola, Smith 3225) have indicated that the two species intergrade in north-western New South Wales and may be better treated as subspecies.

Other Specimens Examined: New South Wales: North Far Western Plains: Yandama Ck track, 32 $\mathrm{km}$ from Hawker Gate, Carolin 13032, May 1979 (SYD); $12 \mathrm{~km}$ from Packsaddle on road to 
Broken Hill, Smith 77, Nov 1973 (SYD); 56 miles [90 km] NNW of Wilcannia on road to White Cliffs, Briggs 2726, May 1969 (NSW); Fowlers Gap-Milparinka 6 miles [10 km], Carolin W84a, June 1956 (SYD); Fowlers Gap, Cunningham $1034 \mathcal{E}$ Milthorpe, Sep 1973 (NSW); 48 km from Wilcannia on road to Broken Hill, Smith 75, Nov 1973 (SYD); Broken Hill, Morris, Dec 1919 (ADW 17450). New SOUTH Wales/SOuth Australia: North Far Western Plains/Lake Eyre: Hawker Gate, Carolin W93, June 1956 (SYD). North Far Western Plains/Eastern: Smithville, Carolin W90, June 1956 (SYD). SOuth Australia: Lake Eyre: Coonanna Bore, Carolin W94, June 1956 (SYD); 0.5 mile [1 km] SW of Hawker Gate, Johnson \& Constable, June 1955 (NSW 66976). Flinders Ranges: Gammon Ra., Boyce 10, Aug 1974 (AD); SE Gammon Ra., Eichler 12889, Sep 1956 (AD); Orroroo, Kenny, Jan 1944 (AD 97915047).

\section{Wahlenbergia littoricola P.J. Smith}

Smith (1986: 1380), as 'litticola'. The epithet, based on Latin littus, coast, and -cola, dweller, was wrongly formed when originally published. This was an unintentional error. The correct combining form of littus is littor- not litt-. Accordingly, the spelling of the epithet is corrected here to littoricola.

TYPE: VICTORIA: Z: 2 km from Mallacoota on Betka Rd, P.J. Smith 100, Mar 1974; holo NSW.

[W. graniticola auct. non Carolin: Grieve \& Blackall (1982: 669)]

Perennial herb with a thickened taproot, tufted, few- to many-stemmed. Stems 10-80 $\mathrm{cm}$ long, erect or ascending, usually becoming much-branched, at least in the inflorescence, lower stem glabrous to hirsute, upper stem glabrous; hairs to $1.9 \mathrm{~mm}$ long. Leaves and bracts alternate or sometimes lowermost opposite, all \pm linear or lowermost oblanceolate, acute to subulate, sometimes lowermost obtuse, sessile, 4-60 mm long, 1-4 mm wide, glabrous to hirsute on lower stem, glabrous on upper stem; margins flat or undulate, entire or with small, distant callus-teeth. Flowers in thyrsoids of varying complexity covering the upper half or more of the plant; pedicels $2-12 \mathrm{~cm}$ long, glabrous; bracteoles linear, 2-10 mm long, glabrous. Hypanthium obconic, 2-3 mm long, glabrous. Sepals 5, \pm erect, \pm narrowly triangular, $2-4 \mathrm{~mm}$ long, glabrous. Corolla shortly campanulate, blue, puberulous inside at base, otherwise glabrous; tube 2-3 $\mathrm{mm}$ long, equal to or shorter than the sepals; lobes 5, elliptic, acute, 5-9 mm long, 2.5$4 \mathrm{~mm}$ wide. Stamens 5; filaments white, $0.9-1.8 \mathrm{~mm}$ long, upper section filiform, lower section rhombic to obtrullate, with or without extended shoulders, usually ciliate on upper margins; anthers 2-4 mm long. Ovary 3-locular. Style white, 4-7 mm long, 3fid, \pm distinctly constricted $1 / 3$ to $2 / 3$ down from the stigmatic lobes, covered with pollen-presenting hairs above the constriction, 1-3 glands below each stigmatic cleft; stigmatic lobes $0.5-1.5 \mathrm{~mm}$ long. Capsule obconic, $3-8 \mathrm{~mm}$ long, $1.5-3.5 \mathrm{~mm}$ wide, glabrous. Seeds c. $0.5 \mathrm{~mm}$ long. Figure $17 \mathrm{e}-\mathrm{g}$.

Chromosome number: $n=27$ (Carolin W36C, W121, W133, Smith 4B, 33, 91, 98, 100, 168); $n=36$ (Carolin W165).

FLOWERING PERIOD: Throughout the year.

Distribution: Widespread in south-eastern Australia, from the McPherson Range, Queensland, through eastern New South Wales, Victoria, Tasmania and south-eastern South Australia, west to Eyre Peninsula. A disjunct population occurs in the far south-west of Western Australia. Figure 30.

HaвiтAT: Grows in forest, woodland, scrub, heath and grassland, often in disturbed sites. Tends to grow amongst other herbs rather than in the open.

Notes: $W$. littoricola is similar to $W$. graniticola and W. aridicola, the three species being characterised by a tufted, branching habit; predominantly alternate leaves; shortly 
campanulate, medium or large corollas; styles with a more or less distinct constriction about halfway down; and hemispherical or obconic capsules. W. littoricola differs from the other two species chiefly in its narrow, mostly linear, lower leaves. It also has generally smaller flowers and tends to have a more multicauleate habit than $W$. graniticola, which has an overlapping distribution. Specimens from eastern New South Wales are usually more or less glabrous, while those from Victoria, Tasmania and South Australia are typically hirsute on the lower stems and leaves.

Selected Specimens (230 examined): QueEnsland: Moreton: Green Mts, McPherson Ra., Smith 2502, Sep 1988 (NSW). NeW SoutH WaLes: North Coast: Ironbark Ridge, Apsley-Macleay Gorges, Smith 1032, Sep 1984 (NSW). Central Coast: $72 \mathrm{~km}$ from Windsor on road to Putty, Smith 33, Nov 1972 (SYD); East Hills, S side of Georges R., Carolin W121, Nov 1956 (SYD); East Hills-Milperra 2 miles [3 km], Carolin W133, Nov 1956 (SYD). South Coast: $8 \mathrm{~km}$ from Moruya on road to Narooma, Smith 98, Mar 1974 (SYD); State Forest between Tilba and Punkella, Carolin W165, Mar 1957 (SYD); $40 \mathrm{~km} \mathrm{~W}$ of Narooma, Briggs 3093, Dec 1969 (NSW). Northern Tablelands: Apsley Falls-Walcha 12 miles [20 km], Briggs (Carolin W113), Nov 1956 (SYD). Central Tablelands:
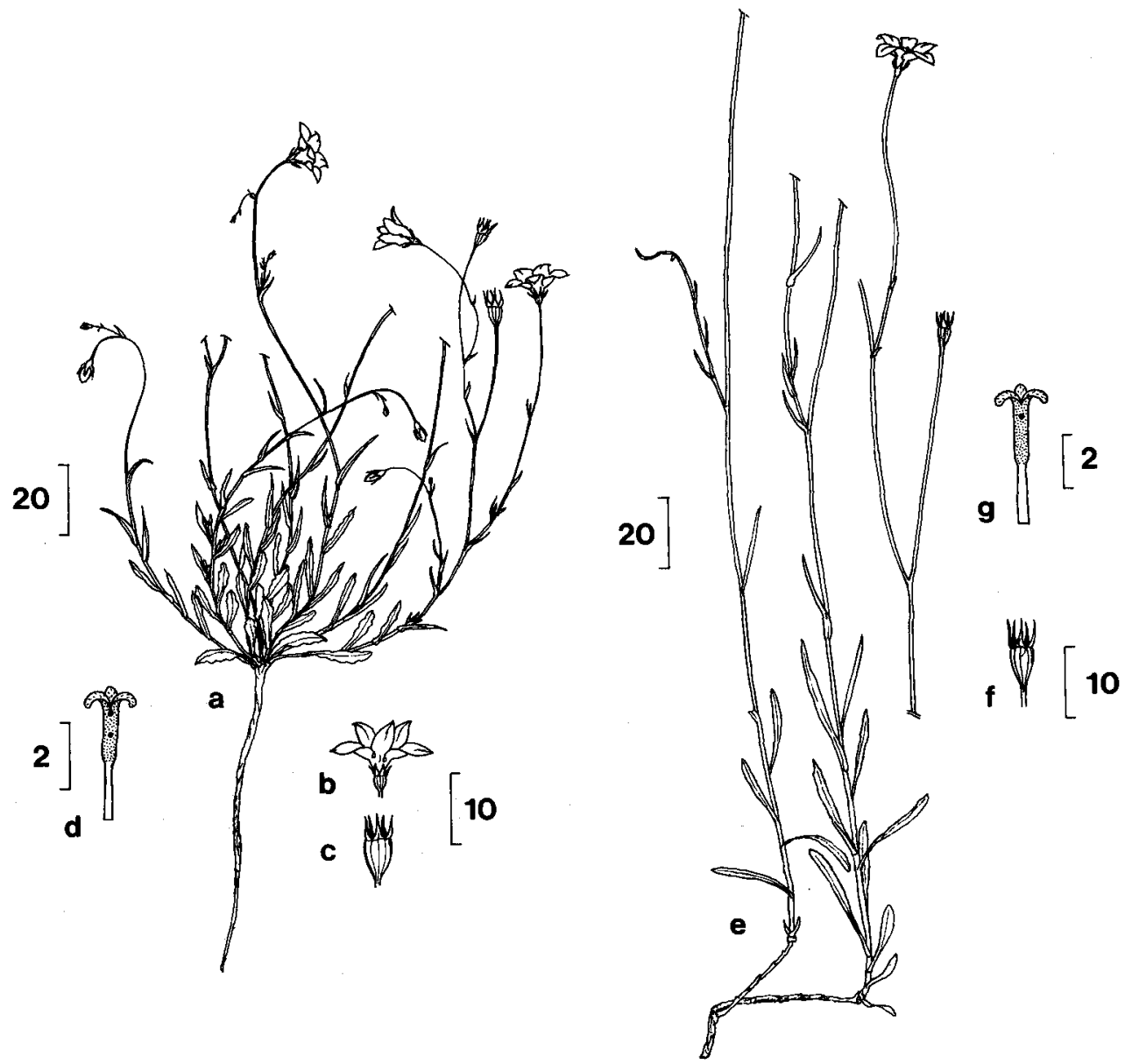

Figure 17. W. aridicola: $\mathbf{a}$, habit; $\mathbf{b}$, flower; $\mathbf{c}$, capsule; $\mathbf{d}$, style. W. littoricola: $\mathbf{e}$, habit; $\mathbf{f}$, capsule; g, style. a-d from Cunningham 1034; $\mathrm{e}-\mathrm{g}$ from Briggs 3093. Scale bars in $\mathrm{mm}$. 
Mittagong, Smith 4B (SYD). Southern Tablelands: Barneys Ridge, Cooma to Jindabyne, Carolin W36C, Feb 1956 (SYD); 12 km from Jindabyne on road to Mt Kosciusko, Smith 91, Mar 1974 (SYD). Australian Capital TerRitory: Black Mt, Taylor 77, Nov 1975 (CBG). Victoria: A: Kulkyne National Forest, Willis, Oct 1960 (MEL 628645). B: Wyperfield Natl Park, Landy \& Beauglehole 5182, Nov 1960 (MEL). C: Wail, Willis, Dec 1959 (MEL 628245). D: Wilkin near Casterton, Beauglehole 8238, Oct 1960 (MEL). F: c. 16 km NNW of Piangil, Macfarlane (Beauglehole 57660), Jan 1973 (MEL). G: 17 km SSW of Swan Hill, Beauglehole 55993 \& Macfarlane, May 1977 (MEL). J: Creswick, Willis, Jan 1944 (MEL 57360). N: Upper Beaconsfield, Opie \& Gullan, Jan 1980 (MEL 628540). P: c. 13 km NW of Anglesea, Beauglehole 49566, Nov 1974 (MEL). T: $3.5 \mathrm{~km} \mathrm{~N}$ of Mirboo North, Beauglehole 62063, Dec 1978 (MEL). V: 2.7 miles [4 km] from Harrietville to Mt Hotham, Canning, Dec 1967 (CBG 024882). W: 2 miles [3 km] W of Bairnsdale, Muir 1986, Nov 1960 (MEL). X: $8 \mathrm{~km}$ from. Sale on road to Bairnsdale, Smith 168, Jan 1975 (SYD). Z: c. $12 \mathrm{~km}$ SE of Orbost, Hunter 27, Nov 1951 (MEL). TASmania: Central Highlands: Breona, Dale (Beauglehole 44005), Jan 1950 (MEL). Western and South-western: Smithton, Barber, Apr 1950 (HO 8332). North-eastern: Coles Bay tip, Allan, Mar 1977 (HO 28467). South Australia: Eyre Peninsula: near Yangie, Alcock 547, Nov 1964 (AD). Murray: c. $20 \mathrm{~km}$ W of Walkers Flat, Donner 992, Mar 1964 (AD). Yorke Peninsula: Pondalowie Bay, Blaylock 59, Oct 1965 (AD). Southern Lofty: Seaton Golf Course, Adelaide, Whibley 3850, Nov 1972 (AD). South-eastern: Messent Wildlife Reserve, James 149, Nov 1965 (AD). Western Australia: Menzies: West Cape Howe, W of Albany, Royce 5401, Mar 1956 (PERTH). Warren: Carey Brook, Donnelly R., Butler, Mar 1965 (PERTH). Eyre: Nancy Peak, Porongorup Ra., Royce 6127, Oct 1959 (PERTH).

\section{Wahlenbergia planiflora P.J. Smith, sp. nov.}

$W$. multicauli et $W$. fluminali affinis, sed a $W$. multicauli lobis corollae $6-14 \mathrm{~mm}$ longis, capsulis hemisphaericis vel obconicis, differt; a W. fluminali caulibus typice paucis, foliis solum summis linearibus, lobis corollae 6-14 mm longis, differt.

TyPE: New South Wales: Central Tablelands: $2 \mathrm{~km}$ from Hartley on road to Lithgow, P.J. Smith 28, 16 Mar 1972; holo NSW.

Perennial herb with a thickened taproot, tufted, typically few-stemmed. Stems $12-70$ $\mathrm{cm}$ long, erect or ascending, usually becoming much-branched, at least in the inflorescence, glabrous to hirsute; hairs to $2 \mathrm{~mm}$ long. Leaves and bracts alternate or sometimes lowermost opposite, obovate to narrowly elliptic on lower stem, lanceolate to linear on upper stem, 4-95 mm long, 1-11 mm wide, obtuse to subulate, sessile, glabrous to hirsute; margins flat or sometimes undulate, entire or with small, distant callus-teeth, sometimes faintly serrate. Flowers in thyrsoids of varying complexity covering the upper half or more of the plant; pedicels 2-14 cm long, glabrous to sparsely hirsute; bracteoles linear, $2-9 \mathrm{~mm}$ long, glabrous to sparsely hirsute. Hypanthium hemispherical to obconic, 1-4 mm long, glabrous to hirsute. Sepals 5, spreading, \pm narrowly triangular, 1-5 mm long, glabrous to hirsute. Corolla rotate, blue or sometimes white, puberulous inside at base and sometimes sparsely hirsute along the veins; tube 1-3 mm long, equal to or shorter than the sepals; lobes 5 , elliptic to obovate, sometimes ovate, obtuse to acute, 6-14 mm long, 3.5-8.5 mm wide. Stamens 5; filaments white, $0.8-2.1 \mathrm{~mm}$ long, upper section filiform, lower section trullate to obtrullate, with or without extended shoulders, ciliate on upper margins; anthers 2$4 \mathrm{~mm}$ long. Ovary 3-locular. Style white, 2.5-6 mm long, 3-fid, deeply constricted no lower than $1 / 3$ down from the stigmatic lobes, covered with pollen-presenting hairs above the constriction, 1-2 glands below each stigmatic cleft; stigmatic lobes $0.5-1.5$ $\mathrm{mm}$ long. Capsule hemispherical to obconic, 2-8 $\mathrm{mm}$ long, 2-5 mm wide, glabrous to hirsute. Seeds c. $0.5 \mathrm{~mm}$ long.

NOTES: Characteristic features of $W$. planiflora are its typically few-stemmed habit; alternate, non-linear lower leaves; large, rotate corollas; styles deeply constricted close below the stigmatic lobes; and hemispherical to obconic capsules. 
The epithet refers to the 'flat-flowered' appearance resulting from the very short corolla-tube. Latin planus, flat, flos, flower.

\section{Key to subspecies}

1 Plants glabrous or sometimes sparsely hirsute on lower stems and leaves; capsules obconic, 3-8 mm long, glabrous a. subsp. planiflora

1* Plants hirsute; capsules hemispherical, 2-6 mm long, usually hirsute b.subsp. longipila

17a. Wahlenbergia planiflora subsp. planiflora

[W. multicaulis auct. non Benth.: Beadle (1984: 769); Stanley \& Ross (1986: 475)]

[W. multicaulis form A, Jacobs \& Pickard (1981: 96)]

Stems 12-65 cm long, glabrous or sometimes lower stem sparsely hirsute; hairs to 1.3 $\mathrm{mm}$ long. Leaves and bracts 4-95 mm long, 1-10 $\mathrm{mm}$ wide, glabrous or sometimes sparsely hirsute on lower stem. Pedicels 2-14 cm long, glabrous; bracteoles 2-9 $\mathrm{mm}$ long, glabrous. Hypanthium obconic, $1.5-4 \mathrm{~mm}$ long, glabrous. Sepals 1-5 mm long, glabrous. Corolla blue; tube 1-3 mm long; lobes $6-13 \mathrm{~mm}$ long, 3.5-7 mm wide. Filaments 1.0-1.9 mm long, lower two-thirds rhombic to obtrullate, with extended shoulders. Style 3-5.5 mm long. Capsule obconic, 3-8 mm long, 2-5 mm wide, glabrous. Figure $18 \mathrm{a}-\mathrm{d}$.

Chromosome number: $n=18$ (Carolin s.n. [Owens Gap], Smith 28, 93, 96); $n=27$ (Carolin W199).

FLOWERING PERIOD: Throughout the year.

DistRibution: South-eastern New South Wales and north-eastern Victoria, from Barrington Tops in the north to Nunniong Plains in the south. Figure 31a.

HABITAT: Grows in forest, woodland and grassland, typically amongst other herbs rather than in the open. Recorded over a wide altitudinal range, from near sea level to about $1500 \mathrm{~m}$.

CONSERvation status: Not considered at risk.

Selected Specimens (56 examined): New South Wales: North Coast: Wingham to Killawarra, c. 2 miles [3 km] W of Wingham, Salasoo 2769, Jan 1964 (NSW); 1 mile [2 km] W of Monkey Jacket, NW of Tea Gardens, Johnson, Oct 1953 (NSW 67116). Central Coast: Lake Macquarie, Myuna Bay, Salasoo 1642, Dec 1958 (NSW); All Saints Cemetery, Albion Park, McBarron 10856, Aug 1965 (NSW). South Coast: Princes Hwy, 1 mile [2 km] S of Nowra, Briggs 3075, Dec 1969 (NSW). Northern Tablelands: Bottom of Corker Lookout, Carolin W199, Apr 1958 (SYD); 'Fingerpost' track to Barrington Tops, Carolin W187, June 1957 (SYD). Central Tablelands: 1 mile [2 km] SW of Lowther, Briggs (Carolin W41), Feb 1956 (SYD); 4 miles [7 km] WNW of Mittagong, Thompson 712, Nov 1970 (NSW). Southern Tablelands: $2 \mathrm{~km}$ from Cooma on road to Adaminaby, Smith 96, Mar 1974 (SYD); $10 \mathrm{~km}$ from Jindabyne on road to Mt Kosciusko, Smith 93, Mar 1974 (SYD); SE of Nimmitabel, Salasoo 1971, Dec 1960 (NSW). Central Western Slopes: Wappinguy Ck near Merriwa, Carolin 6990, Oct 1968 (SYD); Owens Gap, Carolin (SYD). Australian Capital TerriTORY: NE side of Boboyan Divide, Burbidge \& D'Arnay 6974, Mar 1961 (CANB). VictoriA: R: 10 miles [17 km] W of Rutherglen, Muir 4610, Oct 1967 (MEL). V: Cobberas Mts, Beauglehole 36519 \& Finck, Jan 1971 (MEL); W ascent of Cobberas, Wakefield 3010, Jan 1949 (MEL). W: Lake Hill, SW of Nunniong Plains, Beauglehole 36340 \& Finck, Jan 1971 (MEL). 
17b. Wahlenbergia planiflora subsp. longipila Carolin ex P.J. Smith, subsp. nov.

$\mathrm{Ab}$ subsp. planiflora plantis hirsutis, capsulis magis hemisphaericis, typice hirsutis, differt.

TYPE: New SOUTH WALES: North Western Plains: 8 miles [13 km] NE of Boggabri, S. James (R.C. Carolin W137), 15 Nov 1956; holo NSW.

[W. multicaulis form B, Jacobs \& Pickard (1981: 96)]

Stems $12-75 \mathrm{~cm}$ long, hirsute towards base, glabrous to sparsely hirsute above; hairs to $2 \mathrm{~mm}$ long. Leaves and bracts 4-65 mm long, 1-11 mm wide, hirsute on lower stem, glabrous to sparsely hirsute on upper stem. Pedicels 2-13 cm long, usually sparsely hirsute; bracteoles 2-8 mm long, glabrous to sparsely hirsute. Hypanthium hemispherical, 1-3 mm long, usually hirsute. Sepals $1.5-4.5 \mathrm{~mm}$ long, usually hirsute. Corolla blue or sometimes white; tube 1-3 mm long; lobes 6-14 mm long, 4-8.5 mm wide. Filaments $0.8-2.1 \mathrm{~mm}$ long, lower two-thirds trullate to rhombic, with or without extended shoulders. Style 2.5-6 mm long. Capsule hemispherical, 2-6 mm long, 2$5 \mathrm{~mm}$ wide, usually hirsute. Figure $18 \mathrm{e}-\mathrm{h}$.

Chromosome NUMBer: $n=9$ (Carolin 2093, Smith 80); $n=18$ (Carolin 2092, Smith 41, 42, $44,59,83)$.

FLOWERING PERIOD: Throughout the year.

Distribution: South-eastern Queensland and north-eastern New South Wales, from Kingaroy in the north to Dunedoo in the south. Figure 31a.

HABITAT: Grows in forest, woodland and grassland, typically amongst other herbs rather than in the open.

CONSERVATION STATUS: Not considered at risk.

Noтеs: Subsp. longipila differs from subsp. planiflora in its plentiful indumentum (which usually includes the capsules and sepals), and its shorter, more hemispherical capsules. However, occasional specimens within the distribution of each subspecies resemble the other subspecies. Field observations indicated that this was due to variation among individual plants rather than local populations.

The epithet refers to the long-haired indumentum. It was devised by R. Carolin in the 1960 s in his unpublished notes on the species. Latin longus, long, pilus, hair.

Selected Specimens (70 examined): QueEnSLAND: Burnett: Kingaroy-Chahpingah Rd, E of Boyne R., Johnson 468, May 1958 (BRI, CANB, NSW). Darling Downs: Cottonvale-Amiens Rd, Byrnes 3934, Oct 1979 (BRI, NSW); Stanthorpe, Pedley 1423, Oct 1963 (BRI); Moreton: Helidon-Ravensbourne, 1 mile [2 km], Phillips, Aug 1963 (CBG 022922). New South WaLes: Northern Tablelands: $58 \mathrm{~km}$ from Inverell on road to Glen Innes, Smith 83, Dec 1973 (SYD); Nandewar Ra., Carolin 2092, 2093, Jan 1961 (SYD); $2 \mathrm{~km}$ from Bendemeer on road to Tamworth, Smith 80, Dec 1973 (SYD). North Western Slopes: $25 \mathrm{~km}$ from Coonabarabran on road to Narrabri, Smith 59, June 1973 (SYD); $8 \mathrm{~km}$ from Coonabarabran on road to Narrabri, Smith 42, Nov 1972 (SYD); 7 $\mathrm{km}$ from Coonabarabran on road to Binnaway, Smith 41, Nov 1972 (SYD); $18 \mathrm{~km}$ from Coolah on road to Binnaway, Smith 44, Nov 1972 (SYD); Mt Terrible near Currabubula, Johnson, Oct 1951 (NSW 67103). Central Western Slopes: Cobbora, Garden, Oct 1949 (NSW 66776); Coulsons Ck, foot of Liverpool Ra., N of Merriwa, Briggs $2195 \mathcal{E}$ Rodd, Sep 1968 (NSW). North Western Plains: Narrabri-Boggabri Rd, Althofer, Sep 1967 (NSW 133173). 


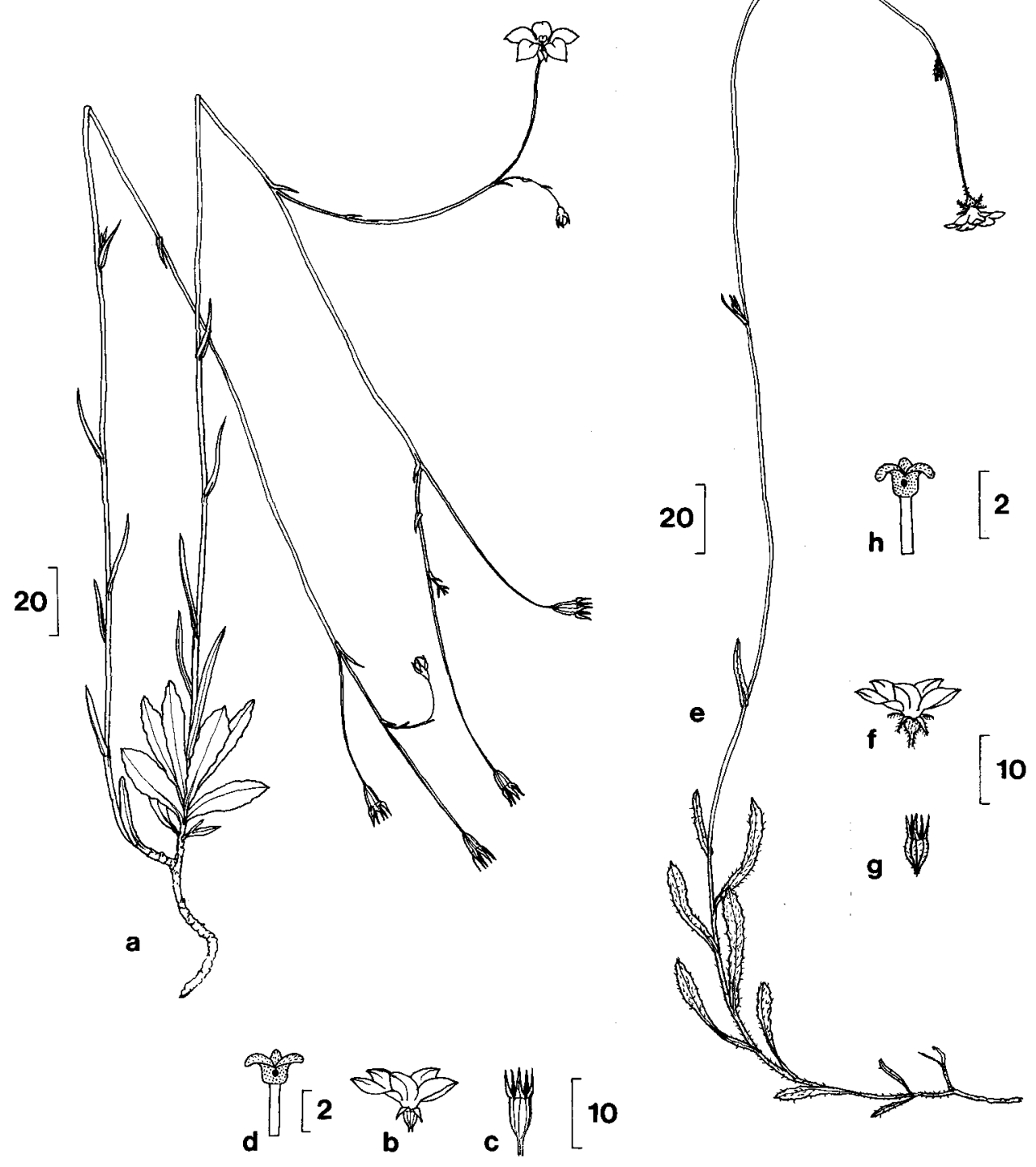

Figure 18. W. planiflora subsp. planiflora: a, habit; b, flower; c, capsule; d, style. W. planiflora subsp. longipila: e, habit; f, flower; g, capsule; h, style. a-d from Salasoo 1971; e-h from NSW 67103. Scale bars in $\mathrm{mm}$. 


\section{Wahlenbergia fluminalis (J. Black) F. Wimmer ex H. Eichler}

Eichler (1963: 297); Carolin (1964: 239); Willis (1972: 626); Cunningham et al. (1981: 627); Beadle (1984: 769); Smith (1986: 1378); Stanley \& Ross (1986: 475). Cephalostigma fluminale Black (1934: 184); Black \& Robertson (1957: 809).

\section{TYPE: SOUTH Australia: Murray: Murray R., S.A. White, Dec 1913; holo AD.}

Perennial herb with a thickened taproot, tufted, typically many-stemmed. Stems 5-80 $\mathrm{cm}$ long, erect or ascending, usually becoming much-branched, glabrous or sometimes lower stem sparsely hirsute; hairs to $1 \mathrm{~mm}$ long. Leaves and bracts alternate, all \pm linear or lowermost oblanceolate, acute to subulate, sometimes lowermost obtuse, sessile, 4-60 mm long, 0.5-5 mm wide, glabrous or sometimes lower leaves sparsely hirsute; margins flat or sometimes undulate, entire or with small, distant callus-teeth. Flowers in thyrsoids of varying complexity covering the upper half or more of the plant; pedicels $2-10 \mathrm{~cm}$ long, glabrous; bracteoles linear, 2-10 $\mathrm{mm}$ long, glabrous. Hypanthium hemispherical to shortly obconic, 1-3 mm long, glabrous. Sepals 5, spreading, \pm narrowly triangular, $1-3 \mathrm{~mm}$ long, glabrous. Corolla rotate, blue, puberulous inside at base, otherwise glabrous; tube $0.5-1.5 \mathrm{~mm}$ long, equal to or shorter than the sepals; lobes 5, elliptic to obovate, obtuse to acute, $3-9 \mathrm{~mm}$ long, 2-5.5 $\mathrm{mm}$ wide. Stamens 5; filaments white, $0.7-1.5 \mathrm{~mm}$ long, upper section filiform, lower section trullate to rhombic, with extended shoulders, ciliate on upper margins; anthers 0.5-2 mm long. Ovary 3-locular. Style white, 2.5-4 mm long, 3-fid, deeply constricted no lower than $1 / 3$ down from the stigmatic lobes, covered with pollen-presenting hairs above the constriction, 1-2 glands below each stigmatic cleft; stigmatic lobes $0.5-1.5 \mathrm{~mm}$ long. Capsule hemispherical to shortly obconic, 2-5 mm long, $1.5-3 \mathrm{~mm}$ wide, glabrous. Seeds c. $0.3 \mathrm{~mm}$ long. Figure 19a-d.

Chromosome number: $n=18$ (Peacock 6110.12C, Smith 46, 62, 67, 69, 69A).

FLOWERING PERIOD: Throughout the year.

DisTRIBUTION: Restricted to the Murray-Darling Basin but widespread within the Basin, from the Darling Downs in the north-east to Mannum in the south-west. Figure $31 \mathrm{~b}$.

НАвІтат: Usually grows on the banks and floodplains of inland watercourses.

CONSERVATION STATUS: Not considered at risk.

Notes: W. planiflora, W. multicaulis and W. fluminalis are all characterised by rotate corollas and styles deeply constricted close below the stigmatic lobes. W. fluminalis differs from $W$. planiflora in its more branched habit, narrow, mostly linear lower leaves, and generally smaller flowers. It differs from $W$. multicaulis in its more branched habit and hemispherical to shortly obconic capsules.

Selected Specimens (169 examined): Queensland: Darling Downs: 'Rockwood', c. 20 miles [33 $\mathrm{km}] \mathrm{E}$ of Condamine, Cameron, Jan 1970 (BRI 114039). Maranoa: Moonie R., c. $50 \mathrm{~km} \mathrm{E}$ of St George, Pedley 782, May 1961 (BRI). New South WALES: Central Western Slopes: 20 miles [33 $\mathrm{km}$ ] S of Dubbo, Peacock 6110.12C, Oct 1961 (SYD); $23 \mathrm{~km}$ from Parkes on road to Peak Hill, Smith 67, Nov 1973 (SYD). South Western Slopes: Billabong Ck, Rand, McBarron 3049, Feb 1949 (NSW). North Western Plains: Nyngan, Smith 62, Oct 1973 (SYD); $47 \mathrm{~km}$ from Cobar on road to Wilcannia, Smith 69, Nov 1973 (SYD). South Western Plains: near Mossgiel, Leigh, Oct 1964 (NSW 77488); Hay, Smith 46, Dec 1972 (SYD). North Far Western Plains: Wilcannia, Smith 69A, Nov 1973 (SYD). South Far Western Plains: Willow Point Stn, Darling R. Anabranch, 65 miles [108 km] N of Wentworth, Johnson \& Constable, Mar 1959 (NSW 47288). VICTORIA: A: Hattah Lakes Natl Park, Beauglehole 17195, Oct 1960 (MEL). B: Wyperfield Natl Park, Muir 896, Oct 1959 (MEL). C: Woraigworm, Little Desert, Beauglehole 1670, Oct 1948 (MEL). F: c. $16 \mathrm{~km}$ SE of Robinvale, Beauglehole 56119, May 1977 (MEL). G: Swan Hill, Gammon (MEL 57183). H: Mt Korong Scenic 
Reserve, Beauglehole 69399, Oct 1981 (MEL). J: near Stawell, Mining Department (MEL 57840). L: Barmah State Forest, Muir 3410, June 1964 (MEL). M: Tabilk Lagoon Wildlife Reserve, Beauglehole 68892, May 1981 (MEL). N: Fryers Ridge Flora Reserve, Beauglehole 70030 \& Blake, Nov 1981 (MEL). Q: Yarrawonga-Cobram, Aston 2202, Jan 1982 (MEL). R: Warby Ra., Sep 1942 (MEL 57493). South Australia: Murray: c. $3 \mathrm{~km}$ NE of the ferry at Mannum, Eichler 14906, Apr 1958 (AD).

\section{Wahlenbergia multicaulis Benth.}

Bentham (1837: 75); N.E. Brown (1913: 337), p.p.; Lothian (1947a: 229); Grieve \& Blackall (1982: 668); Smith (1986: 1381); Wheeler (1987: 599); [misapplied by Beadle (1984: 769) and Stanley \& Ross (1986: 475)]. W. gracilis f. multicaulis (Benth.) Wawra (1883: 132).

Type: Western Australia: Drummond: Swan R., C. von Hïgel; lecto W (Lothian 1947a: 229); isolecto $\mathrm{K}$.

Lothian mistakenly stated that the lectotype was at GOET, but the specimen at $W$ has been labelled by him 'undoubtedly the type' ( $\mathrm{R}$. Carolin, pers. comm.).

W. simplicicaulis Vriese (1848: 241); Lothian (1947a: 209); Grieve \& Blackall (1982: 668). TYPE: WESTERN AUSTRALIA: interior regions of south-western Australia, L. Preiss 1887, Nov 1840; lecto MEL (Lothian 1947a: 209); isolecto L.

W. tadgellii Lothian (1947a: 228); Curtis (1963: 409); Willis (1972: 626); Beadle et al. (1982: 432), p.p. TYPE: Victoria: P: Torquay, T.R.N. Lothian, Oct 1943; holo MEL 57254.

Lobelia dubia Vriese (1848: 242). TyPe: Western Australia: Drummond: near 'Pine-Aple', Perth, L. Preiss 1440, 7 Oct 1839; holo G.

Perennial herb with a thickened taproot, tufted, typically few-stemmed. Stems 10-75 cm long, erect or ascending, usually becoming much-branched, at least in the inflorescence, glabrous throughout or lower stem sparsely hirsute; hairs to $1.5 \mathrm{~mm}$ long. Leaves and bracts alternate or sometimes lowermost opposite, all \pm linear or lower leaves obovate to oblanceolate, acute to subulate, sometimes lowermost obtuse, sessile, 4-80 mm long, 1-6 mm wide, glabrous or lower leaves sparsely hirsute; margins flat, entire or with small, distant callus-teeth. Flowers in thyrsoids of varying complexity covering the upper half or more of the plant; pedicels $2-13 \mathrm{~cm}$ long, glabrous; bracteoles linear, 2-9 mm long, glabrous. Hypanthium elongated-obconic or sometimes obconic, $2-7 \mathrm{~mm}$ long, glabrous. Sepals 5 , spreading, \pm narrowly triangular, $0.5-$ $5.5 \mathrm{~mm}$ long, glabrous. Corolla rotate, blue, puberulous inside at base, otherwise glabrous; tube $0.5-1.5 \mathrm{~mm}$ long, equal to or shorter than the sepals; lobes usually 5 , sometimes 4 or 6, elliptic to obovate, obtuse to acute, 2-9 mm long, 1-5.5 mm wide. Stamens 5; filaments white, $0.7-2.0 \mathrm{~mm}$ long, upper section filiform, lower section trullate to obtrullate, with or without extended shoulders, ciliate on upper margins; anthers $0.5-2.5 \mathrm{~mm}$ long. Ovary 3-locular or sometimes 2-locular. Style white, 2-5.5 mm long, 3-fid or sometimes 2-fid, deeply constricted no lower than $1 / 3$ down from the stigmatic lobes, covered with pollen-presenting hairs above the constriction, $0-1$ gland below each stigmatic cleft; stigmatic lobes $0.5-1.5 \mathrm{~mm}$ long. Capsule elongated-obconic or sometimes obconic, 4-12.5 mm long, 1.5-4.5 mm wide, glabrous. Seeds c. 0.4 $\mathrm{mm}$ long. Figure $19 \mathrm{e}-\mathrm{h}$.

Chromosome number: $n=18$ (Smith 169); $n=27$ (Carolin W149A, W173, Smith 29, 51, 94, 95, 97, 161); $n=36$ (Carolin W17B).

FLOWERING PERIOD: Throughout the year. 


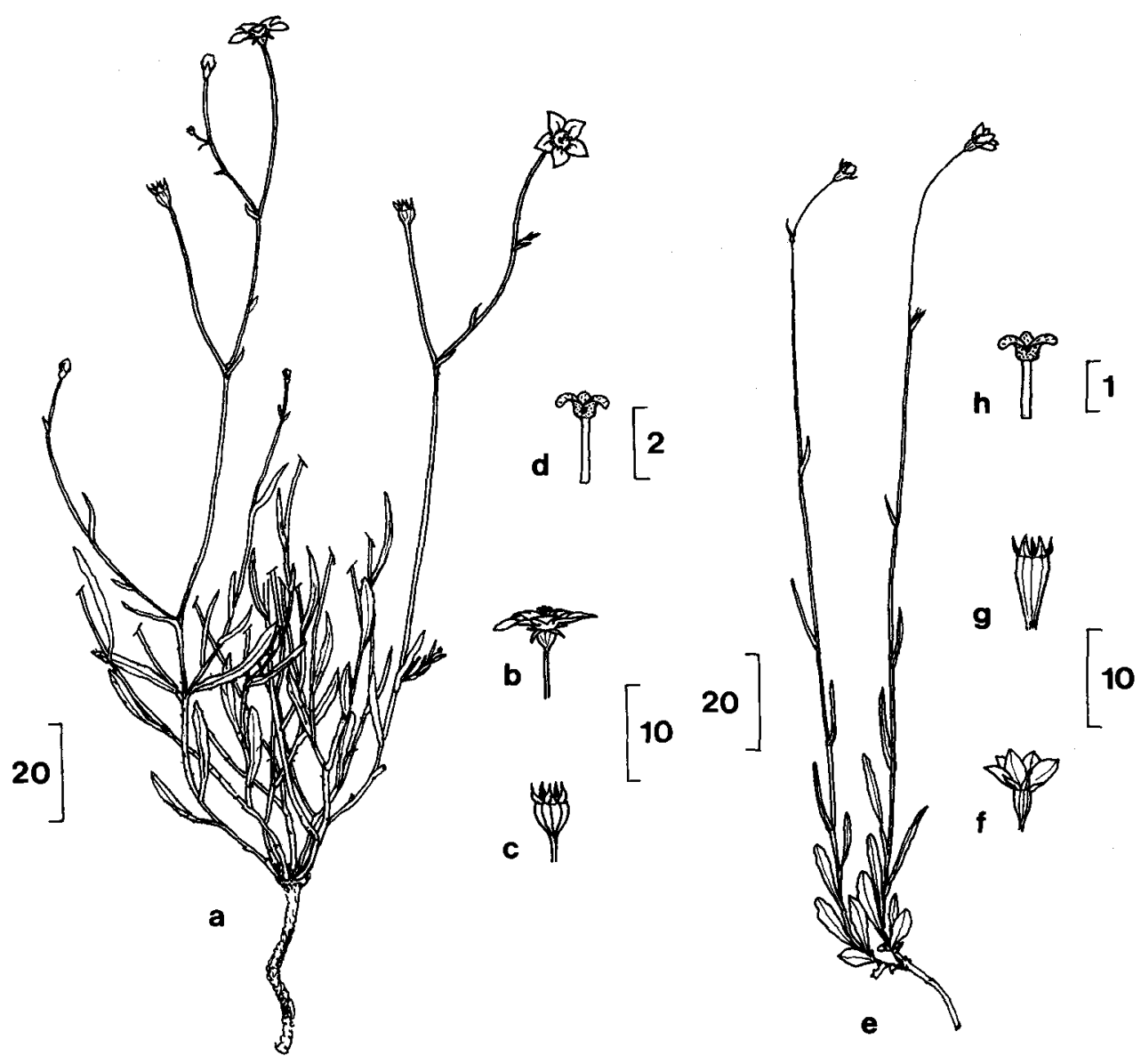

Figure 19. W. fluminalis: $\mathbf{a}$, habit; $\mathbf{b}$, flower; $\mathbf{c}$, capsule; $\mathbf{d}$, style. W. multicaulis: $\mathbf{e}$, habit; f, flower; g, capsule; $\mathbf{h}$, style. a-d from NSW 77488; e-f from Pullen 2407; g-h from Briggs 2500. Scale bars in $\mathrm{mm}$.

Distribution: Widespread in south-eastern Australia, from the Blue Mountains in the north-east to Hobart in the south and Kangaroo Island in the west. Also occurs widely in south-western Australia, from Rat Island in the north-west to Cape Arid in the south-east. Figure 32.

HABITAT: Grows in forest, woodland and grassland, typically amongst other herbs rather than in the open. Recorded over a wide altitudinal range, from near sea level to about $1500 \mathrm{~m}$.

CONSERVATION STATUS: Not considered at risk.

Notes: Characteristic features of $W$. multicaulis are its relatively small, rotate corollas; styles deeply constricted close below the stigmatic lobes; and elongated-obconic capsules. There is some variation in flower size but specimens with larger corollas are usually large in all flower parts, so that the corollas still appear small in relation to the hypanthium and sepals. 
Selected Specimens (305 examined): New South Wales: Central Coast: Punchbowl, Green, Apr 1953 (NSW 66813). South Coast: $8 \mathrm{~km}$ from Moruya on road to Narooma, Smith 97, Mar 1974 (SYD). Central Tablelands: Clwydd, Smith 29, Mar 1972 (SYD); $17 \mathrm{~km}$ from Bathurst on road to Lithgow, Smith 51, Dec 1972 (SYD); 2 miles [3 km] E of Sodwalls, Carolin W17B, Dec 1955 (SYD). Southern Tablelands: Braidwood-Moruya, 5 miles [8 km], Carolin W173, Mar 1957 (SYD); 2 km from Kiandra on road to Adaminaby, Smith 94, Mar 1974 (SYD); $17 \mathrm{~km}$ from Adaminaby on road to Kiandra, Smith 95, Mar 1974 (SYD); Sawpit Ck-Jindabyne, 2 miles [3km], Carolin W149A, Mar 1957 (SYD); Bradleys Ck, 3 miles [5 km] E of Yaouk, NNE of Adaminaby, Briggs 2500, Feb 1969 (NSW). South Western Slopes: Monument Hill, Albury, McBarron 3287, May 1949 (NSW). South Western Plains: Millewa State Forest, Millewa River Rd, c. 4 km E of Toupna Crossing Rd, Smith 2367, Nov 1987 (NSW). Australian Capital Terrrtory: Blue Gum Ck, upper Paddys R., c. 2 miles [3 km] S of 'Booroomba' Stn, Pullen 2407, Nov 1960 (CANB, NSW). VICTORIA: C: Mt Arapiles, Grampians, Beauglehole 16615, Oct 1964 (MEL). D: Wilkin near Casterton, Beauglehole 8246, Oct 1960 (MEL). E: Lower Glenelg Natl Park, Beauglehole 7079 \& Willis, Jan 1965 (MEL). H: c. $7 \mathrm{~km}$ WSW of Inglewood, Beauglehole 50188, Aug 1975 (SYD). J: Major Mitchell Plateau, Grampians, Beauglehole 16486, Dec 1967 (MEL). K: Port Campbell Natl Park, Beauglehole 21544 \& Finck, Oct 1966 (MEL). M: Bendigo, Smith 161, Jan 1975 (SYD). N: Eltham, St John, Sep 1927 (MEL 57674). P: Narre Warren East, Beauglehole 7015, Oct 1945 (MEL). R: Cornishtown via Chiltern, Cleaves, 1942 (MEL 57497). S: Eildon, Muir 1608, Oct 1960 (MEL). T: c. 5 miles [8 km] E of Traralgon, Melville 2155, Nov 1952 (K, MEL). V: c. $50 \mathrm{~km}$ SSE of Tallangatta, Wilson, Dec 1961 (MEL 628364). W: McKillops Bridge, Snowy R., Muir 2075, Mar 1961 (MEL). X: 8 km from Sale on road to Bairnsdale, Smith 169, Jan 1975 (SYD). Z: Tubbut, Wakefield 4786, Jan 1953 (MEL). TASMANIA: Bass Strait Islands: Little Green Island, Furneaux Group, Whinray 1014, Jan 1975 (MEL). Central Highlands: Forest Lagoon, Verwood Rd, Brown 165, Jan 1981 (HO, MEL, AD). Western and South-western: Domain, Hobart, Gulline, Aug 1949 (HO 8349). North-eastern: Little Musselroe Bay, Moscal 2926, Sep 1983 (HO). South Australia: Northern Lofty: Spring Gully Conservation Park, Yeatman 225, Oct 1980 (AD). Murray: Kaiserstuhl Conservation Park, Spooner 7390, Nov 1980 (AD). Southern Lofty: Mt Compass, Hunt 3302, Oct 1970 (AD). Kangaroo Island: upper part of South West R., Cleland, Nov 1954 (AD). South-eastern: Big Heath Reserve, Hunt 2585, Nov 1965 (AD). Western Australia: Irwin: Rat I., Sammy 115, Sep 1972 (PERTH). Drummond: Byford, Cranfield 1080, Nov 1979 (PERTH). Dale: Darling Ra., Wilson 11610, Oct 1973 (PERTH). Menzies: Margaret R., Royce 105, Jan 1945 (PERTH). Eyre: c. 45 km NW of Bremer Bay, Newbey 5087, Sep 1977 (PERTH). Roe: 1 mile [2 km] E of Tambellup, Newbey 1185, Oct 1963 (PERTH). Avon: banks of Swan R., 2-4 miles [3-7 km] above Northam, Salasoo 170, Oct 1949 (NSW).

\section{Wahlenbergia gracilis (Forster f.) A. DC.}

De Candolle (1830: 142); [Schrader (1827: 38) indicated but did not validly make the combination]; Hooker (1852: 159), (1856: 239), p.p.; Bentham (1869: 137), p.p.; Moore \& Betche (1893: 302), p.p.; Bailey (1900: 922), p.p.; Rodway (1903: 107), p.p.; N.E. Brown (1913: 316); Ewart (1930: 1060), p.p.; Carolin (1964: 240); Cunningham et al. (1981: 628); Beadle et al. (1982: 433); Beadle (1984: 771); Smith (1986: 1378); Stanley \& Ross (1986: 476); [misapplied by Carolin (1981: 349)]. Campanula gracilis Forster (1786: 84); R. Brown (1810: 561), p.p. Cervicina gracilis (Forster f.) Britten (1901: 56).

Type: New Caledonia or New Zealand: J.R. \& J.G.A. Forster; lecto GOET (Carolin 1964: 240); isolecto BM, K, KIEL.

W. quadrifida (R. Br.) de Candolle (1830: 144); N.E. Brown (1913: 317); Domin in Diels (1929: 638); Lothian (1947a: 210); Black \& Robertson (1957: 811); Curtis (1963: 409); Willis (1972: 625); [misapplied by Black (1934: 183)]. Campanula quadrifida R. Brown (1810: 561); Sweet (1830: 326). Type: New South Wales: Central Coast: around Port Jackson, R. Brown (Bennett 2615); lecto BM (Lothian 1947a: 210); isolecto K.

W. sieberi de Candolle (1830: 144); Black (1934: 183); Lothian (1947a: 219); Black \& Robertson (1957: 811). Campanula sieberi (A. DC.) Dietrich (1839: 752). TYPE: Australia: New Holland, F.W. Sieber 577; holo G; iso P. 
W. dioica Domin (1929: 639). TYPe: QueEnsland: Cook: near Chillagoe, K. Domin, Feb 1910; lecto PR Domin 8750 (here chosen); isolecto PR Domin 8749.

W. eurycarpa Domin (1929: 638). TyPe: New SOUth WALEs: Central Tablelands: Blue Mts at Katoomba, K. Domin 8741, Apr 1910; holo PR.

[W. vinciflora (Vent.) Decaisne (1849: 41), as 'vincaeflora'. C. vinciflora Ventenat (1803: 12), as 'vincaeflora', nom. illeg. (Stearn 1951: 169; Carolin 1964: 236) $\equiv$ C. gracilis Forster (1786: 84). C. gracilis (var) $\alpha$ vinciflora (Vent.) R. Brown (1810: 561), as 'vincaeflora'. W. gracilis var. vinciflora (Vent.) Hooker (1856: 239), as 'vincaeflora'. The name $C$. vinciflora was superfluous when first published as it included, as a synonym, C. gracilis Forster $\mathrm{f}$. Its type is therefore that of $W$. gracilis, although the epithet has generally been misapplied to $W$. stricta.]

[W. gracilis var. minutiflora Bailey (1900: 922), nom. nud.]

[W. marginata var. neo-caledonica Lothian (1947a: 214), nom. illeg. (Carolin 1964: 240). Lothian based var. neo-caledonica on part of the type collection of $C$. gracilis Forster $\mathrm{f}$., namely the isolectotype at K.]

Perennial herb with a thickened taproot, tufted, few- to many-stemmed. Stems 5-80 $\mathrm{cm}$ long, erect or ascending, usually becoming much-branched, at least in the inflorescence, glabrous or lower stem sparsely hirsute; hairs to $1.3 \mathrm{~mm}$ long. Leaves and bracts alternate throughout or lower leaves opposite, becoming alternate above, obovate to narrowly elliptic on lower stem, lanceolate to linear on upper stem, obtuse to subulate, sessile, $2-60 \mathrm{~mm}$ long, $0.2-10 \mathrm{~mm}$ wide, lower leaves glabrous to sparsely hirsute, upper leaves glabrous; margins flat or undulate, entire or with small, distant callus-teeth, sometimes faintly serrate. Flowers in thyrsoids of varying complexity covering the upper half or more of the plant; pedicels $2-11 \mathrm{~cm}$ long, usually glabrous, sometimes sparsely hirsute; bracteoles linear, $1.5-5 \mathrm{~mm}$ long, glabrous. Hypanthium obconic to obovoid, 1-3 mm long, glabrous. Sepals 5 or sometimes 3 or 4 , \pm erect, \pm narrowly triangular, 1-3 mm long, glabrous. Corolla deeply campanulate, usually blue, sometimes white or pink, puberulous inside at base, otherwise glabrous; tube 1-4.5 $\mathrm{mm}$ long, varying from shorter to longer than the sepals; lobes 5 or sometimes 3 or 4, elliptic to ovate, acute, $1.5-6 \mathrm{~mm}$ long, 1-3 mm wide. Stamens 5 or sometimes 3 or 4; filaments white, $0.7-1.8 \mathrm{~mm}$ long, upper section filiform, lower section trullate to obtrullate, with or without extended shoulders, ciliate on upper margins; anthers 1$3 \mathrm{~mm}$ long. Ovary 3-locular or sometimes 2-locular. Style white, $1.5-6.5 \mathrm{~mm}$ long, 3fid or sometimes 2 -fid, unconstricted or indistinctly constricted $1 / 3$ to $2 / 3$ down from the stigmatic lobes, covered with pollen-presenting hairs above this point, $0-3$ glands below each stigmatic cleft; stigmatic lobes $0.3-1.2 \mathrm{~mm}$ long. Capsule obconic to obovoid, 2.5-7 mm long, 1.5-3.5 mm wide, glabrous. Seeds c. $0.3 \mathrm{~mm}$ long. Figure 20a-d.

Chromosome nUmber: $n=27$ (Carolin W5, W82, W110, W120, Smith 21, 30, 31, 32, 71, 89, 107, 113). H. Gulline (in Darlington \& Wylie 1955: 289) also reported a count of $n=$ 27, probably from Tasmania, but there is no voucher specimen to check the identification. J. Petterson (pers. comm.) has made an unpublished count of $n=36$ on material from New Caledonia.

FLOWERING PERIOD: Throughout the year.

Distributron: Widespread in eastern Australia from Cape York Peninsula to southern Tasmania, extending west to the McArthur River in the Northern Territory and the Adelaide area in South Australia. The species also occurs in New Guinea, New Caledonia and New Zealand. Figure 33b. 
HАBITAT: Grows in many vegetation types, often in disturbed sites, including lawns and gardens. Typically grows amongst other herbs rather than in the open.

CONSERvation Status: Not considered at risk.

NoTES: Characteristic features of W. gracilis are its perennial habit; small, deeply campanulate corollas; and obconic to obovoid capsules.

A number of authors have treated $W$. gracilis as a much more broadly defined taxon encompassing various Wahlenbergia species in Australasia (e.g. Bentham 1869: 137, Allan 1961: 788) and southern Asia (e.g. Hooker 1881: 429). Other authors have reduced W. gracilis to synonymy with a very broadly defined W. marginata (Thunb.) A. DC. (e.g. Lothian 1947a: 212, Tuyn 1960: 115). Although further studies are needed on the morphological and geographic limits of Wahlenbergia species in Asia and Malesia, I do not consider any Australian material to be referable to W. marginata of Japan.

Selected SPecimens (362 examined): QueensLAND: Burnett: $58 \mathrm{~km} \mathrm{~W}$ of Eidsvold, $2 \mathrm{~km} \mathrm{NW}$ of Redbank Ck bridge, Johnson 7149 \& Briggs, June 1971 (NSW). Cook: $8 \mathrm{~km}$ E of Babinda, McDonald \& Batianoff 1508, Apr 1975 (BRI). Darling Downs: Chinchilla, Lithgow, July 1978 (BRI 241691). Leichhardt: c. $80 \mathrm{~km}$ SW of Rolleston, Crisp 3072, June 1977 (CBG, BRI). Moreton: West Burleigh, Smith 31, May 1972 (SYD). North Kennedy: Hinchinbrook I., Cape Richards, Everist 9646, Aug 1970 (BRI). Port Curtis: Round Hill Head, 2410' S, 151 ${ }^{\circ} 54^{\prime}$ E, Everist, Mar 1970 (BRI 214539). South Kennedy: Mackay, Stanley \& Ross 78257, Nov 1978 (BRI). Wide Bay: $1 \mathrm{~km} \mathrm{~N}$ of Coolum Beach, Sharpe 2017, Apr 1976 (BRI). New South WALEs: Lord Howe Island: Northern Hills, Hoogland 8700, Oct 1963 (CANB, NSW). North Coast: $15 \mathrm{~km}$ from Kempsey on road to Armidale, Smith 32, May 1972 (SYD); Warkworth, Smith 30, Apr 1972 (SYD). Central Coast: Sanitation Depot, Pearl Beach, Carolin W5, Oct 1955 (SYD); Castle Hill, Barlow (Carolin W82), May 1956 (SYD); Longueville, Smith 21, Mar 1972 (SYD); East Hills-Milperra 1 mile [2 km], Carolin W120, Nov 1956 (SYD). South Coast: S slope of Mt Coolangatta, SE of Berry, Salasoo 3147, Jan 1966 (NSW). Northern Tablelands: $8 \mathrm{~km}$ from Glen Innes on road to Grafton, Smith 89, Dec 1973 (SYD). Central Tablelands: Bell-Lithgow 3 miles [5 km], Carolin W110, Nov 1956 (SYD). Southern Tablelands: Greenwich Rd near Wollondilly R., Goulburn District, Salasoo 5050, Sep 1972 (NSW). North Western Slopes: Mt Martha, 8 km SW of Curlewis, Briggs 2998, Nov 1969 (NSW). Central Western Slopes: 12 miles [20 km] NW of Coolah, Johnson \& Briggs 954, Oct 1966 (NSW). South Western Slopes/Southern Tablelands: 3 miles [5 km] from Khancoban, Phillips \& Carroll, Oct 1965 (CBG 025271). North Western Plains: $3 \mathrm{~km}$ from Nyngan on road to Tottenham, Smith 71, Nov 1973 (SYD). South Western Plains: southern tip of Cocoparra Ra., Smith 113, Apr 1974 (SYD). Australian Captal Territory: Canberra, Cleland, Jan 1939 (AD 966071624). Victoria: D: above 'The Nook', Grampians, Symon 58, Nov 1959 (ADW). E: Mt Eccles Natl Park, Beauglehole 44016, Oct 1960 (MEL). J: Grampians, Major Mitchell Plateau, Beauglehole 16547, Dec 1967 (MEL). K: Otway Ra., Muir 1833, Nov 1960 (MEL). L: Ulupna I. Reserve, 3 miles [5 km] NW of Strathmerton, Muir 4703, Oct 1969 (MEL). N: Dandenong Ra., Muir 733, Mar 1959 (MEL). P: French I., $38^{\circ} 24^{\prime} \mathrm{S}, 145^{\circ} 21^{\prime} \mathrm{E}$, Opie \& van Berkel, Dec 1980 (MEL 581212). S: Warburton-Cement Ck, Tadgell, Oct 1937 (MEL 57446). T: 4 km NE of Leongatha, Beauglehole 61866, Dec 1978 (MEL). V: Bogong massif, E of Tawonga, Eichler 14796, Feb 1958 (AD). W: Ensay, Tadgell, Nov 1938 (MEL 57235). Z: Bastion Point, Mallacoota, Smith 107, Mar 1974 (SYD). TASMANIA: Bass Strait Islands: Deal I., Kents Group, Whinray 85a, Dec 1968 (NSW). Central Highlands: Forth Falls, Gulline, May 1950 (HO 8324). Western and South-western: Mt Wellington, Gulline, Apr 1950 (HO 8315). Northeastern: Bluestone Tier, Moscal 8147, May 1984 (HO). South Australia: Southern Lofty: Mt Lofty Botanic Garden, SW section, Weber 538, Apr 1967 (AD). Northern Territory: Darwin and Gulf: McArthur R. area, $16^{\circ} 04^{\prime}$ S, $136^{\circ} 28^{\prime}$ E, Craven 4692, July 1977 (CANB). New GuinEA: Tovobada Hills, c. 8 miles [13 km] NNW of Port Moresby, Pullen (BRI 084320). New Calendonia: Plateau de Dogny, McKee 8197, Jan 1961 (CANB). New ZEALAND: Awarua Bay, Southland, Powell, Dec 1974 (CHR 358039, AD). 


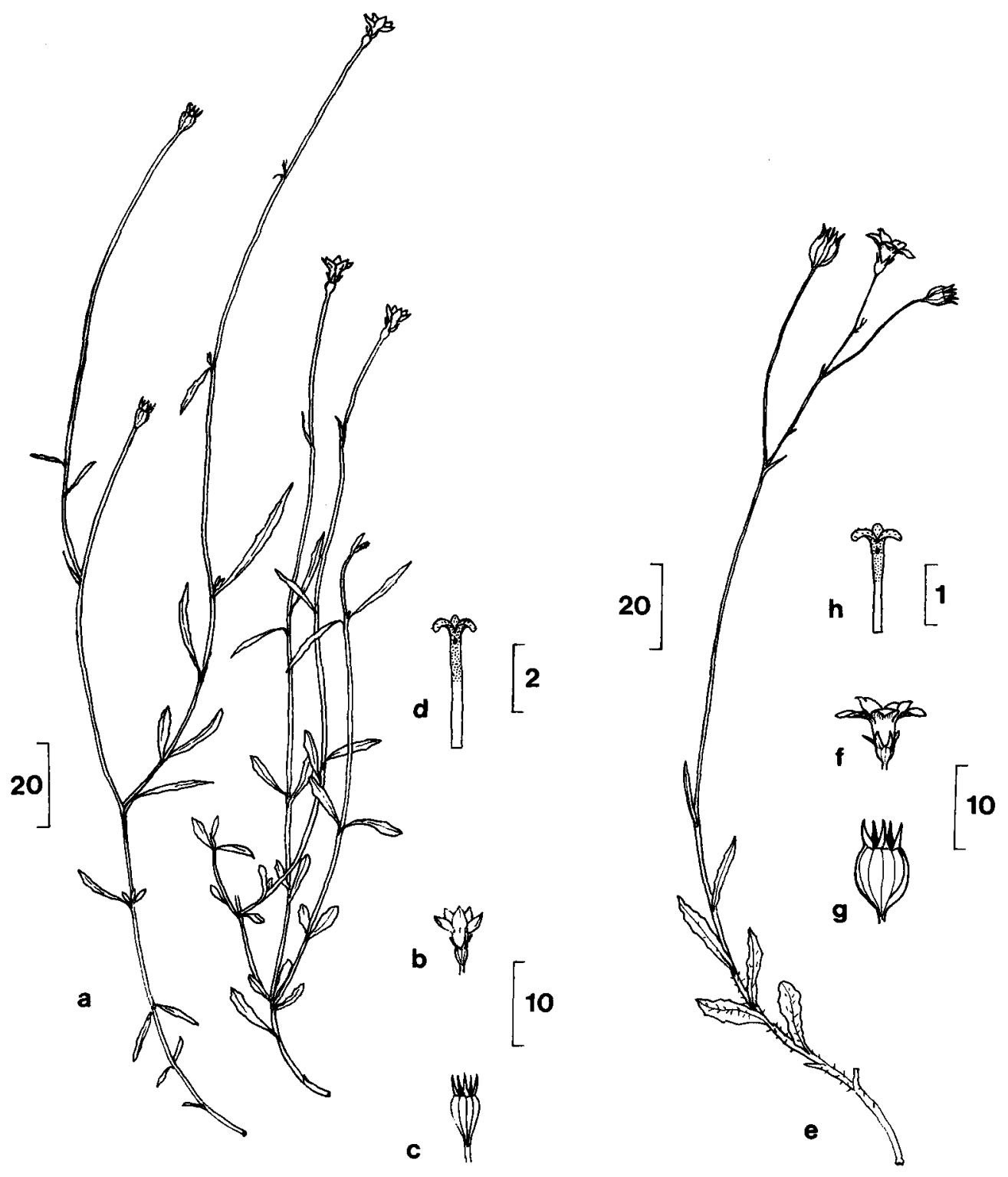

Figure 20. W. gracilis: a, habit; $\mathbf{b}$, flower; c, capsule; d, style. W. tumidifructa: $\mathbf{e}$, habit; f, flower; g, capsule; h, style. a-d from Salasoo 3147; e-h from NSW 120470. Scale bars in mm. 


\section{Wahlenbergia tumidifructa $P$.J. Smith}

Smith (1986: 1383).

Type: New South Wales: North Western Plains: $85 \mathrm{~km}$ from Cobar on road to Wilcannia, P.J. Smith 73, 4 Nov 1973; holo NSW.

[W. species B, Jacobs \& Pickard (1981: 96)]

[W. species B, Carolin (1981: 350)]

[W. gracilis auct. non (Forster f.) A. DC.: Carolin (1981: 350)]

Annual herb with a slender taproot, single- or few-stemmed, or perennial, tufted herb with a thickened taproot, few- to many-stemmed. Stems $4-90 \mathrm{~cm}$ long, erect or ascending, usually becoming much-branched, at least in the inflorescence, lower stem \pm hirsute, upper stem glabrous, sometimes glabrous throughout; hairs to $1.5 \mathrm{~mm}$ long. Leaves and bracts alternate or sometimes lowermost opposite, obovate to narrowly elliptic on lower stem, lanceolate to linear on upper stem, obtuse to subulate, sessile, 2-60 mm long, $0.2-12 \mathrm{~mm}$ wide, \pm hirsute on lower stem, glabrous on upper stem, sometimes all glabrous; margins flat or undulate, entire or with small, distant callus-teeth, sometimes faintly serrate. Flowers in thyrsoids of varying complexity covering the upper half or more of the plant; pedicels 2-11 cm long, glabrous or sometimes sparsely hirsute; bracteoles linear, 1.5-6 mm long, glabrous or sometimes sparsely hirsute. Hypanthium globose, cylindric or elongated-obconic, often appearing swollen, especially in perennials, $1-3 \mathrm{~mm}$ long, glabrous. Sepals 5, \pm erect, \pm narrowly triangular, 1-4 mm long, glabrous. Corolla deeply campanulate, usually blue, sometimes white or pink, puberulous inside at base, otherwise glabrous; tube 1-5 mm long, varying from shorter to longer than the sepals; lobes 5, elliptic, acute, 2-7 mm long, 1-3.5 mm wide. Stamens 5; filaments white, $0.7-1.5 \mathrm{~mm}$ long, upper section filiform, lower section rhombic to obtrullate, with or without extended shoulders, ciliate on upper margins; anthers 1-3 mm long. Ovary 3-locular. Style white, 2.5-6 mm long, 3-fid, unconstricted or indistinctly constricted $1 / 3$ to $2 / 3$ down from the stigmatic lobes, covered with pollen-presenting hairs above this point, $0-3$ glands below each stigmatic cleft, the uppermost gland often elongated; stigmatic lobes $0.5-1 \mathrm{~mm}$ long. Capsule globose, cylindric or elongated-obconic, often appearing swollen, especially in perennials, $2.5-9 \mathrm{~mm}$ long, $2-4.5 \mathrm{~mm}$ wide, glabrous. Seeds c. $0.4 \mathrm{~mm}$ long. Figure 20e-h.

Chromosome number: $n=27$ (Carolin W84, W88, W89, W92, W92A, Smith 63, 73, 76, 78, $138,143 A, 143 B, 144,148)$.

FLOWERING PERIOD: Throughout the year.

DistRIBUTION: Widespread in arid and semi-arid regions of Australia, occurring in all mainland states. Figure 34.

HABITAT: Grows in a variety of arid and semi-arid vegetation types, typically in open sites, including disturbed sites such as roadsides.

CONSERVATION STATUS: Not considered at risk.

Notes: Characteristic features of $W$. tumidifructa are its alternate leaves; small, deeply campanulate corollas; and capsules that are globose, elongated-obconic or cylindric, and typically appear swollen. Occasional specimens with a slightly larger corolla (lobes $\geq 6 \mathrm{~mm}$ long) also have a larger hypanthium, so that the corolla still appears small by comparison. 
Selected Specimens (538 examined): QueEnSLAND: Burke: $26 \mathrm{~km} \mathrm{~W}$ of Mt Isa, Schmid 219, July 1977 (BRI). Darling Downs: 55 km from Roma on road to Yuleba, Smith 148, Sep 1974 (SYD). Gregory North: $78 \mathrm{~km}$ from Mt Isa on road to Dajarra, Smith 138, Sep 1974 (SYD). Gregory South: Diamantina R., just N of Queensland/South Australia border, Lothian 517, Aug 1960 (AD, NT). Maranoa: 12 miles [20 km] N of St George, 6118, Sep 1959 (BRI). Mitchell: Barcaldine, Smith 143A, 143B, 144, Sep 1974 (SYD). South Kennedy: $120 \mathrm{~km}$ NW of Clermont, Dale 133, July 1977 (BRI). Warrego: Warrego R., W of Cunnamulla, Pedley 2434, Sep 1967 (BRI). New SoutH WaLEs: North Western Plains: 3 miles [5 km] SE of Byrock, Thompson, Sep 1969 (NSW 120470); $28 \mathrm{~km}$ from Bourke on road to Wanaaring, Smith 63, Oct 1973 (SYD); $162 \mathrm{~km}$ from Wilcannia on road to Cobar, Smith 78, Nov 1973 (SYD). South Western Plains: 32 miles [53 km] N of Deniliquin, Leigh, Aug 1968 (NSW 87871). North Far Western Plains: near Avenel Homestead, Carolin W88, June 1956 (SYD); Fowlers Gap-Milparinka 6 miles [10 km], Carolin W84, June 1956 (SYD); 48 km from Wilcannia on road to Broken Hill, Smith 76, Nov 1973 (SYD). South Far Western Plains: Mungo Natl Park, 12 km from Mungo Homestead towards Mildura, Canning \& Lodder 4741, Oct 1979 (CBG). New South Wales/SOuTH Australia: North Far Western Plains/Lake Eyre: Hawker Gate, Carolin W92, W92A, June 1956 (SYD). North Far Western Plains/Eastern: Smithville, Carolin W89, June 1956 (SYD). VICTORIA: A: Hattah Lake, Beauglehole 44021, Sep 1960 (MEL). B: Big Desert, Ackland 56, Sep 1963 (MEL). SOUTH Australia: North-western: Musgrave Ra., Mt Caroline, Weber 5608, Sep 1978 (AD). Lake Eyre: Less Hill, c. $25 \mathrm{~km} \mathrm{~S} \mathrm{of} \mathrm{Stuart} \mathrm{Ck} \mathrm{Homestead,} \mathrm{Chorney} \mathrm{1080,} \mathrm{Oct}$ 1978 (AD). Nullarbor: Barton, on transcontinental railway, Ising, Sep 1920 (AD 97644176). Gairdner-Torrens Basin: Mt Gunson Mines, Jones, Oct 1974 (AD 97451179). Flinders Ranges: c. $24 \mathrm{~km}$ S of Moolawatana, Whibley 2537, Aug 1968 (AD). Eastern: c. $10 \mathrm{~km}$ W of Quinyambie Homestead, Whibley 3530, July 1971 (AD, PERTH, NT). Eyre Peninsula: Childara Rockhole, Weber 3242, Sep 1972 (AD). Murray: c. $120 \mathrm{~km}$ NNE of Morgan, Wilson 2192, Sep 1961 (AD). Yorke Peninsula: c. $140 \mathrm{~km}$ NNW of Adelaide, Copley 1906, Apr 1968 (AD, NSW). WESTERN AustRAliA: Hall: c. $16 \mathrm{~km} \mathrm{~S}$ of Wolf Ck Meteorite Craters turnoff, Carr \& Beauglehole 47410, July 1974 (MEL). Canning: Rudall R. Natl Park, Mitchell 859, Apr 1979 (NT, PERTH). Carnegie: Elder Ck, c. 2 miles [3 km] W of Warburton Mission, George 3922, Aug 1962 (PERTH). Giles: S end of Dean Ra., Carolin 6091, Aug 1967 (NSW). Helms: c. 30 km W of Plumridge Lakes, Crisp, Taylor $\mathcal{E}$ Jackson 5845, Sep 1979 (CBG). Eucla: 8 miles [13 km] E of Rawlinna, Aplin \& Trudgen 5786, June 1974 (PERTH). Fortescue: Bamba Pool, Harding R., Weston 12780, Sep 1981 (PERTH). Ashburton: $6 \mathrm{~km} \mathrm{SE}$ of Ashburton Downs, Toelken 6344, Sep 1979 (AD). Carnarvon: $74 \mathrm{~km}$ E of Carnarvon, Wilson 8401, July 1969 (PERTH). Austin: Belele Stn NNW of Meekatharra, Goodall 3413, Aug 1965 (PERTH). Irwin: 3-15 miles [5-25 km] S of Binnu on the NW Coastal Hwy, Tindale 1310A, Mar 1970 (NSW, SYD). Avon: Karolin, Helms, Nov 1891 (MEL 57381, AD). Coolgardie:

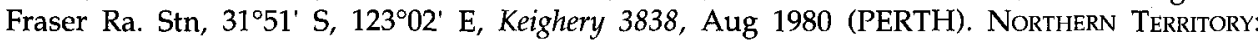
Barkly Tableland: Powells Ck, Central Australia, Holtze, 1894 (MEL 57663). Central Australia North: 20 miles [33 km] N of Huckitta Homestead, Latz 1072, Jan 1971 (NT). Central Australia South: Alice Springs Flora Reserve, Chippendale, Oct 1958 (NT 5070, SYD).

\section{Wahlenbergia gracilenta Loth.}

Lothian (1947a: 217); Black \& Robertson (1957: 810); Curtis (1963: 407); Burbidge \& Gray (1970: 344); Willis (1972: 625); Cunningham et al. (1981: 628); Grieve \& Blackall (1982: 668); Beadle (1984: 771); Smith (1986: 1378).

TYPE: TASMANIA: Bass Strait Islands: Flinders I., J. Milligan 629, 21 Nov 1845; lecto MEL 57109 (here chosen); isolecto MEL 57110, MEL 57111, BM.

[W. quadrifida auct. non (R. Br.) A. DC.: Black (1934: 183)]

Annual herb with a slender taproot, single- or few-stemmed. Stems $1.5-35 \mathrm{~cm}$ long, erect or ascending, usually branched, at least in the inflorescence, glabrous to hirsute, typically lower stem hirsute, upper stem \pm glabrous; hairs to $1.5 \mathrm{~mm}$ long. Leaves and bracts usually opposite on lower stem, becoming alternate above, sometimes alternate throughout, obovate to elliptic on lower stem, ovate to lanceolate on upper stem, obtuse to subulate, sessile, $1-40 \mathrm{~mm}$ long, $0.2-11 \mathrm{~mm}$ wide, glabrous to hirsute, 
typically lower leaves hirsute, upper leaves \pm glabrous; margins flat or sometimes undulate, entire or with small, distant callus-teeth. Flowers sometimes solitary but usually in thyrsoids of varying complexity covering the upper half or more of the plant; pedicels 1-15 cm long, glabrous to sparsely hirsute; bracteoles lanceolate, $0.5-$ $8 \mathrm{~mm}$ long, glabrous to sparsely hirsute. Hypanthium ellipsoid or globose, $0.5-3 \mathrm{~mm}$ long, glabrous to hirsute. Sepals usually 5 , sometimes 3 or 4 , \pm erect, narrowly oblong, 0.5-4 mm long, glabrous to hirsute. Corolla deeply campanulate, usually blue, sometimes white or pink, puberulous inside at base, otherwise glabrous or sometimes sparsely hirsute; tube $0.5-4 \mathrm{~mm}$ long, usually similar in length to the sepals; lobes usually 5 , sometimes 3 or 4 , elliptic, acute, $0.5-5 \mathrm{~mm}$ long, $0.3-2.5 \mathrm{~mm}$ wide. Stamens usually 5 , sometimes 3 or 4 ; filaments white, $0.5-1.8 \mathrm{~mm}$ long, upper section filiform, lower section triangular, oblong or rhombic, with or without extended shoulders, ciliate on upper margins; anthers $0.5-2.0 \mathrm{~mm}$ long. Ovary usually 3-locular, sometimes 2-locular. Style white, $0.5-5.5 \mathrm{~mm}$ long, usually 3-fid, sometimes 2 -fid, \pm distinctly constricted $1 / 4$ to $1 / 2$ way down from the stigmatic lobes, covered with pollen-presenting hairs above the constriction, $0-1$ gland below each stigmatic cleft; stigmatic lobes $0.1-1.0 \mathrm{~mm}$ long. Capsule ellipsoid or globose, $1-7 \mathrm{~mm}$ long, $0.6-6 \mathrm{~mm}$ wide, glabrous to hirsute. Seeds c. $0.4 \mathrm{~mm}$ long. Figure $21 \mathrm{a}-\mathrm{d}$.

CHromosome NUMBER: $n=18$ (Smith 65, 76A). H. Gulline (in Darlington \& Wylie 1955: 289) reported a count of $n=9$, probably from Tasmania, but there is no voucher specimen to check the identification.

FLOWERING PERIOD: July-February.

Distribution: Widespread in Tasmania and across southern mainland Australia. All records are south of latitude $30^{\circ} \mathrm{S}$, except for one record from Dirk Hartog Island. Figure 35.

HABITAT: Grows in a variety of mesic and semi-arid vegetation types, typically in open sites.

CONSERVATION STATUS: Not considered at risk.

Notes: Characteristic features of $W$. gracilenta are its annual, single- or few-stemmed habit; opposite, obovate to elliptic, typically hirsute lower leaves; lanceolate bracteoles; narrowly oblong sepals; small, deeply campanulate corollas; and ellipsoid to globose, often hirsute capsules.

Selected Specimens (505 examined): New South Wales: Southern Tablelands: Queanbeyan, $M c-$ Kee 9636, Oct 1962 (NSW). North Western Slopes: Calala near Tamworth, Monk, Oct 1951 (NSW 67168). Central Western Slopes: Mt Duke, Wellington, Althofer, Oct 1966 (NSW 120484). South Western Slopes: Bulgandry Reserve, Bulgandry, McBarron 3796, Oct 1949 (NSW). North Western Plains: $183 \mathrm{~km}$ from Bourke on road to Nyngan, Smith 65, Oct 1973 (SYD). South Western Plains: Deniliquin, Whaite 2153, Nov 1960 (NSW). North Far Western Plains: Silverton, Smith 76A, Nov 1973 (SYD). South Far Western Plains: near Lake Victoria, Mulham, Oct 1978 (NSW). Australian CaPITAL Territory: between Mts Ainslie and Majura, Beeton, Oct 1964 (NSW 82200). VICTORIA: A: $83 \mathrm{~km}$ SW of Mildura, Crisp 3346, Oct 1977 (CBG, MEL). B: Wyperfield Natl Park, W of Lake Albacutya, Cheel, Sep 1978 (MEL 1507173). C: Little Desert Natl Park, Muir 6360, Nov 1978 (MEL). D: Grampians, near Glenisla Stn, Muir 1493, Oct 1960 (MEL). E: Gorae West, Portland, Beauglehole 44018, 1946 (MEL). G: Swan Hill, Gammon (MEL 57151). H: c. 7 miles [12 km] SW of Inglewood, Muir 1366, Oct 1960 (MEL). J: 2 miles [3 km] W of Maryborough, Muir 1461, Oct 1960 (MEL). M: Bendigo, Robbins (Beauglehole 44004), Sep 1948 (MEL). N: c. 9 miles [15 km] W of Castlemaine, Muir 1444, Oct 1960 (MEL). P: Quail I., Western Port Bay, Melville 2108, Nov 1952 (K, MEL, NSW, AD). R: Warby Ra., Mason, Oct 1960 (MEL 57282). T: Snake I., 25 km SSW of Yarram, Beauglehole 62185, Dec 1978 (MEL). W: Sperm Whale Head, Gippsland, Muir 2298, Oct 1961 (MEL). Z: upper Rodger R., East Gippsland, Chesterfield, Feb 1983 (MEL 626315). TASMANIA: Bass Strait Islands: Cape Barren I., Whinray 550, Oct 1973 (MEL). Western and Southwestern: Sundown Point, Moscal 479, Nov 1980 (HO). North-eastern: Bridport, Curtis, Nov 1952 (HO 53383). SOUTH Australia: Flinders Ranges: 11 miles [18 km] N of Wilpena on floodplain of 

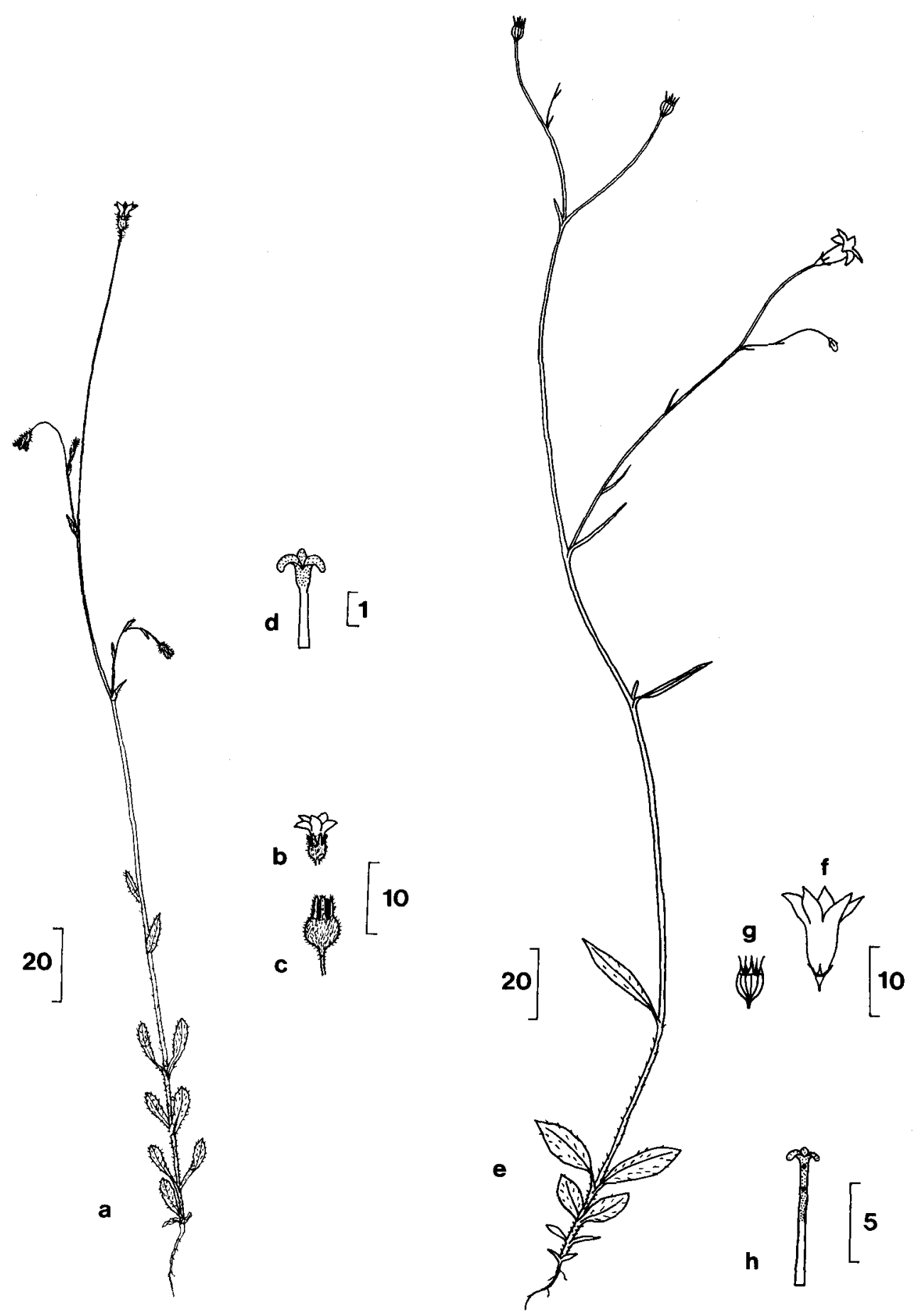

Figure 21. W. gracilenta: a, habit; $\mathbf{b}$, flower; $\mathbf{c}$, capsule; d, style. W. caryophylloides: $\mathbf{e}$, habit; $\mathbf{f}$, flower; g, capsule; h, style. a,b,d from NSW 82200; c from NSW 67168; e-h from Gittins 994. Scale bars in $\mathrm{mm}$. 
Wilpena Ck, Lothian 1474, Sep 1955 (AD). Eastern: Koonamore, outstation, Aug 1923 (AD 97739075). Eyre Peninsula: Marble Ra., slopes of N block, Weber 5985, Sep 1979 (AD). Northern Lofty: Napperby Gorge, Spooner 6012, Sep 1978 (AD). Murray: Billiatt Flora and Fauna Reserve, Cleland, Oct 1960 (AD 97229152). Yorke Peninsula: Innes Natl Park, Alcock 4954, Oct 1974 (AD). Southern Lofty: Black Hill, Athelstone, Spooner 4760, Sep 1976 (AD). Kangaroo Island: Flinders Chase, Rocky R., Wheeler 1262, Oct 1968 (AD). South-eastern: c. 16 km NE of Keith, Specht, Sep 1952 (AD 97417231). Western Australia: Irwin: C. $5 \mathrm{~km} \mathrm{~N}$ of Cape Ransonnet, Dirk Hartog I., George 11408, Sep 1972 (PERTH). Menzies: Busselton, Stoward, Nov 1912 (NSW 67171). Warren: Mt Chudalup, S of Northcliffe, Aplin 1431, Dec 1961 (PERTH). Eyre: Middle I., Recherche Archipelago, Weston \& Trudgen 8836, Nov 1973 (PERTH, CANB). Avon: Wongan Hills, Kenneally 6917, Sep 1978 (PERTH). Coolgardie: Queen Victoria Rock, Wittwer W1943, Nov 1976 (PERTH).

\section{Wahlenbergia preissii Vriese}

Vriese (1848: 241); Grieve \& Blackall (1982: 668); Smith (1986: 1381); Wheeler (1987: 600).

TYPe: Western Australia: Eyre: on a sandy hill near the town of Albany (Plantagenet), L. Preiss 1890, 25 Sep 1840; lecto MEL (here chosen).

Annual herb with a slender taproot, single- or few-stemmed. Stems $6-40 \mathrm{~cm}$ long, erect or ascending, usually branched, at least in the inflorescence, lower stem \pm hirsute, upper stem glabrous; hairs to $1.2 \mathrm{~mm}$ long. Leaves and bracts opposite on lower stem, alternate on upper stem, obovate to narrowly elliptic on lower stem, lanceolate to linear on upper stem, obtuse to subulate, sessile, 2-30 mm long, 0.5-6 mm wide, lower leaves \pm hirsute, upper leaves glabrous; margins flat or sometimes undulate, usually with small, distant callus-teeth. Flowers sometimes solitary but usually in thyrsoids of varying complexity covering the upper half or more of the plant; pedicels 2-8 cm long, \pm glabrous; bracteoles linear, 1-8 mm long, \pm glabrous. Hypanthium elongated-obconic, 2-4 mm long, usually glabrous, sometimes with short hairs. Sepals $5, \pm$ erect, narrowly oblong, 1-2.5 mm long, usually glabrous, sometimes with short hairs. Corolla shortly campanulate, usually blue, sometimes white, puberulous inside at base, otherwise glabrous; tube $0.5-1.5 \mathrm{~mm}$ long, equal to or shorter than the sepals; lobes 5, elliptic, acute, 1.5-4 mm long, 0.8-2.5 mm wide. Stamens 5; filaments white, 0.7-1.5 mm long, upper section filiform, lower section triangular to oblong, without extended shoulders, usually ciliate on upper margins; anthers $0.5-1.5 \mathrm{~mm}$ long. Ovary 2-locular. Style white, 2-3.5 mm long, 2-fid, distinctly constricted about 1/3 down from the stigmatic lobes, covered with pollen-presenting hairs above the constriction, without glands; stigmatic lobes $0.4-0.8 \mathrm{~mm}$ long. Capsule elongated-obconic, $3-7 \mathrm{~mm}$ long, $0.8-2.2 \mathrm{~mm}$ wide, usually glabrous, sometimes with short hairs. Seeds c. $0.3 \mathrm{~mm}$ long. Figure $22 \mathrm{a}-\mathrm{d}$.

FLOWERING PERIOD: August-November.

DistRIBUTION: South-western Australia, from Geraldton in the north-west to Israelite Bay in the south-east. There are also isolated populations in South Australia (northern Eyre Peninsula and the Adelaide area). Figure 36.

HABITAT: Grows in open sites in a variety of vegetation types.

CONSERVATION STATUS: Not considered at risk at species level or in Western Australia, but has a restricted and disjunct distribution in South Australia.

Notes: Characteristic features of $W$. preissii are its annual, single- or few-stemmed habit; opposite lower leaves; narrowly oblong sepals; small, shortly campanulate corollas; 2-locular ovaries and 2-fid styles; and elongated-obconic capsules. 
Selected Specimens (38 examined): South Australia: Eyre Peninsula: Wudinna, Ising, Sep 1939 (AD 97616182); Hambidge Flora and Fauna Reserve, Alcock 1137, Oct 1966 (AD). Southern Lofty: Black Hill, Athelstone, Spooner 3082, Sep 1973 (AD). Western Australla: Irwin: $19 \mathrm{~km}$ E of Dongara, Cranfield 1950a, Sep 1981 (PERTH); Lake Indoon, Hnatiuk 770883, Sep 1977 (PERTH). Drummond: West Perth, Helms, Sep 1898 (NSW 67017); Kings Park, Wittwer 2284, Oct 1979 (PERTH, CANB); South Perth, Cranfield R419, Oct 1980 (PERTH). Dale: Helena Valley, Seabrook 297, Sep 1977 (PERTH). Menzies: 18 miles [30 km] W of Nannup, Royce 2920, Oct 1948 (PERTH). Eyre: Chillitup, Pallinup R., Gardner 6504, Oct 1942 (PERTH). Roe: Israelite Bay, Brooke, 1885 (MEL 57607). Avon: Northam-Perth Hwy, 4-6 miles [7-10 km] from Northam, Salasoo 111, Sep 1949 (NSW).

\section{Wahlenbergia victoriensis $P . J$. Smith, sp. nov.}

$W$. gracilentae et $W$. preissii affinis, sed a W. gracilenta sepalis anguste triangularibus, lobis corollae $\geq 6 \mathrm{~mm}$ longis, 2-4-plo tubo, differt; a $W$. preissii bracteis lanceolatis, sepalis anguste triangularibus, lobis corollae $\geq 6 \mathrm{~mm}$ longis, ovario 3-loculato, stylo 3fido, capsulis ellipsoideis vel globosis, differt.

TYPE: VICTORIA: R: near Killawarra, 10 miles [17 km] NW of Wangaratta, T.B. Muir 1708, 1 Nov 1960; holo MEL.

Annual herb with a slender taproot, single- or few-stemmed. Stems $10-40 \mathrm{~cm}$ long, erect or ascending, usually branched, at least in the inflorescence, lower stem \pm hirsute, upper stem glabrous; hairs to $1.5 \mathrm{~mm}$ long. Leaves and bracts opposite on lower stem, alternate on upper stem, obovate to elliptic on lower stem, ovate to lanceolate on upper stem, obtuse to subulate, sessile, 2-35 mm long, 0.5-7 mm wide, lower leaves \pm hirsute, upper leaves glabrous; margins flat or sometimes undulate, \pm entire. Flowers sometimes solitary but usually in thyrsoids of varying complexity covering the upper half or more of the plant; pedicels 2-12 cm long, \pm glabrous; bracteoles lanceolate, 2-9 mm long, \pm glabrous. Hypanthium ellipsoid or globose, $1-3 \mathrm{~mm}$ long, usually glabrous, sometimes sparsely hirsute. Sepals $5, \pm$ erect, narrowly triangular, 2-5 mm long, usually glabrous, sometimes sparsely hirsute. Corolla shortly campanulate, usually blue, sometimes white, puberulous inside at base, otherwise glabrous; tube 1.5-3.5 mm long, equal to or shorter than the sepals; lobes 5, elliptic to ovate, acute, 6-12 $\mathrm{mm}$ long, 3-8 $\mathrm{mm}$ wide. Stamens 5; filaments white, $0.8-1.2 \mathrm{~mm}$ long, upper section filiform, lower section rhombic with extended shoulders, ciliate on upper margins; anthers 2-3 mm long. Ovary 3-locular. Style white, 4-7 mm long, 3-fid, \pm distinctly constricted $1 / 3$ to $2 / 3$ down from the stigmatic lobes, covered with pollenpresenting hairs above the constriction, 1-2 glands below each stigmatic cleft; stigmatic lobes 0.8-1.2 mm long. Capsule ellipsoid or globose, 3-6 mm long, 2-4 mm wide, usually glabrous, sometimes sparsely hirsute. Seeds c. $0.5 \mathrm{~mm}$ long. Figure $22 \mathrm{e}-\mathrm{g}$.

FLOWERING PERIOD: August-January.

Distribution: Victoria and New South Wales, from Orange in the north-east to Hawkesdale in the south-west. Figure 36.

HaBITAT: Grows in open sites in eucalypt woodland, grassland and saltbush plains. Recorded locations have ranged from floodplains to dry, stony ridges.

CONSERVATION STATUS: Reasonably widespread and occurring in a variety of habitats, but an uncommon species within its range and not often collected.

Notes: Characteristic features of $W$. victoriensis are its annual, single- or few-stemmed habit; opposite, obovate to elliptic lower leaves; lanceolate bracteoles; narrowly triangular sepals; shortly campanulate corollas with lobes $\geq 6 \mathrm{~mm}$ long; and ellipsoid or 
globose capsules.

The epithet refers to the species' occurrence in Victoria.

Selected Specimens (29 examined): New South Wales: Central Tablelands: Four Mile Ck via Orange, Giles, Dec 1961 (SYD). Central Western Slopes: Murrumburrah, Friedricks, 1887 (MEL 57573). South Western Plains: 20 miles [33 km] S of Hay, Semple 1118, Oct 1981 (NSW); $50 \mathrm{~km}$ E of Hay, Semple 1630, Oct 1983 (NSW); 9 miles [15 km] N of Moama, Filson 5411, Oct 1963 (MEL). VICTORIA: C: Nhill, D'Alton (MEL 57567). D: Mt Bepcha, the Grampians, Beauglehole 30005, Dec 1969 (MEL). E: Hawkesdale, Williamson, Nov 1902 (NSW 5334). L: Ulupna Island Reserve, 3 miles [5 km] NW of Strathmerton, Muir 4704, Oct 1969 (MEL). M: Corop, SE of Rochester, Beattie, Oct 1962 (MEL 56930). P: Torquay, Lothian, Oct 1934 (MEL 56926). R: Reef Hills Regional Park, SW of Benalla, Beauglehole 66128, Nov 1979 (SYD).

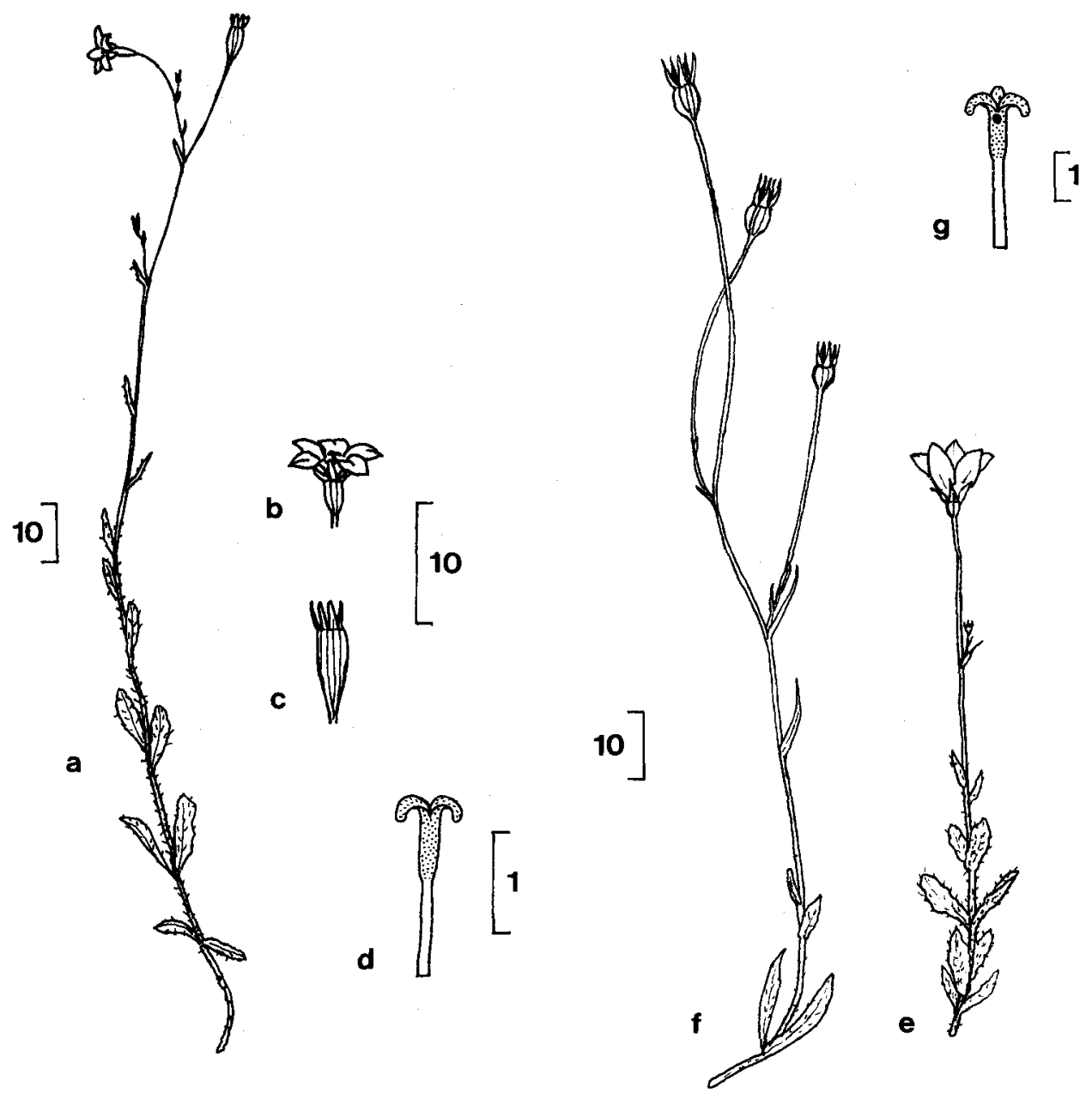

Figure 22. W. preissii: a, habit; $\mathbf{b}$, flower; c, capsule; $\mathbf{d}$, style. W. victoriensis: $\mathbf{e}, \mathbf{f}$, habit; $\mathbf{g}$, style. ac from Salasoo 111; d from NSW 67017; e from Semple 1118; f-g from Semple 1630. Scale bars in $\mathrm{mm}$. 


\section{Wahlenbergia caryophylloides $P$.J. Smith}

Smith (1989: 63).

TyPe: QueEnsLand: Cook: Kennedy Rd, 15 miles [25 km] N of Musgrave, C.H. Gittins 994, Aug 1965; holo NSW; iso BRI.

Annual herb with a slender taproot, single- or few-stemmed. Stems $13-85 \mathrm{~cm}$ long, erect or ascending, usually branched, at least in the inflorescence, lower stem \pm hirsute, upper stem glabrous; hairs to $1.5 \mathrm{~mm}$ long. Leaves and bracts opposite on lower stem, becoming alternate above, elliptic on lower stem or sometimes lowermost obovate, narrowly elliptic to linear on upper stem, obtuse to subulate, sessile, 5-45 $\mathrm{mm}$ long, 1-10 mm wide, lower leaves \pm hirsute, upper leaves glabrous; margins usually flat with small, distant callus-teeth. Flowers in thyrsoids of varying complexity covering the upper half or more of the plant; pedicels $1.5-10 \mathrm{~cm}$ long, glabrous, usually very slender; bracteoles linear, 1-8 mm long, glabrous. Hypanthium hemispherical to cylindric, 1-2 mm long, glabrous. Sepals 5, \pm erect, \pm narrowly triangular, 1-3.5 mm long, glabrous. Corolla deeply campanulate, blue to purple, sometimes white or pink, entirely glabrous; tube $2-8 \mathrm{~mm}$ long, usually longer than the sepals, often rather swollen in the middle; lobes 5, elliptic, acute, often shorter than the tube, $1-6.5 \mathrm{~mm}$ long, 0.6-3 mm wide. Stamens 5; filaments white, 1-2.5 mm long, upper section filiform, lower section trullate to obtrullate, with or without extended shoulders, ciliate on upper margins; anthers 1-4 mm long. Ovary 2- or 3-locular. Style white, $2.5-9 \mathrm{~mm}$ long, 2- or 3-fid, unconstricted, the upper half covered with pollen-presenting hairs, 1-2 glands below each stigmatic cleft; stigmatic lobes $0.5-1.5 \mathrm{~mm}$ long. Capsule hemispherical to cylindric, 2-6.5 mm long, 1-3 mm wide, glabrous. Seeds c. $0.4 \mathrm{~mm}$ long. Figure 21e-h.

FLOWERING PERIOD: May-October, with one record in February.

DistRIBUTION: Widespread in the wetter tropical regions of Queensland, the Northern Territory and Western Australia. The species may well occur in New Guinea and Indonesia, but I have seen no specimens to confirm this. Figure 36.

HABITAT: Often grows on the edges of swamps, lagoons and streams, but also found in drier sites in eucalypt woodland. A preference for sandy soils is indicated.

CONSERVATION STATUS: Not considered at risk.

NOTES: Characteristic features of $W$. caryophylloides are its annual, single- or fewstemmed habit; opposite, elliptic lower leaves; linear bracteoles; narrowly triangular sepals; and deeply campanulate, entirely glabrous corollas with lobes often shorter than the tube.

Specimens may be divided into those with large flowers (corolla tube c. $7 \mathrm{~mm}$ long, lobes c. $6 \mathrm{~mm}$ long, e.g. Gittins 994, Byrnes 2365 and Beauglehole 4196) and those with small flowers (corolla tube c. $3 \mathrm{~mm}$ long, lobes c. $2 \mathrm{~mm}$ long, e.g. Craven 4817, Kanis 1717 and Beauglehole 3044). Both types occur throughout the species' range and without obvious ecological separation.

Selected Specimens (98 examined): QueENSLAND: Burke: Circle Lagoon, $18^{\circ} 02^{\prime} \mathrm{S}, 141^{\circ} 48^{\prime} \mathrm{E}$, Craven 4817, July 1977 (CANB). Cook: Badu I., Torres Strait, Garnett 129, July 1979 (BRI); Davies Ck Forestry Rd, c. 15 miles [25 km] E of Mareeba, Schodde 3315, Aug 1963 (CANB, BRI, AD). North Kennedy: Louisa Lake, c. $8 \mathrm{~km} \mathrm{~S}$ of Lyndhurst, Lazarides 8180, Aug 1976 (CANB, BRI); near Pentland, Blake 19310, July 1954 (BRI). NoRTHERN Territory: Darwin and Gulf: near Mt Saunders, Gove, Byrnes 2365, July 1971 (NT, DNA, CANB); 8 miles [13 km] N of Mudginberri, Byrnes 819, May 1968 (NT). Barkly Tableland: 1746' S, 137²43' E, Kanis 1717, June 1974 (CANB, NT); Attack Ck, Carr \& Beauglehole 46306, July 1974 (MEL). Western Australia: Gardner: $15 \mathrm{~km}$ W of Lake Argyle turnoff, Carr \& Beauglehole 3044, July 1974 (MEL); Rocky Cove, Vansittart Bay, 
Gardner 1519, Aug 1921 (PERTH); Blyxa Ck, 15²48'S, 12520' E, George 12569, Aug 1974 (PERTH). Fitzgerald: Adcock Gorge, Carr \& Beauglehole 4196, July 1974 (MEL). Dampier: Camballin, Power 845, May 1970.

26. *Wahlenbergia capensis (L.) A. DC.

De Candolle (1830: 136); Lothian (1947a: 220); Grieve \& Blackall (1982: 669); Wheeler (1987: 599). Campanula capensis Linnaeus (1753: 169).

TYPE: An illustration by Commelin (1701: t. 35).

[W. elongata (Willd.) Schrader ex Roth (1821: 399). C. elongata Willdenow (1814: 10), nom. illeg.]

[Roella decurrens Andrews (1802: t. 238), nom. illeg.]

Annual herb with a slender taproot, single- or few-stemmed. Stems $14-50 \mathrm{~cm}$ long, erect or ascending, usually only sparingly branched, hirsute; hairs to $2.3 \mathrm{~mm}$ long. Leaves and bracts alternate or lowermost opposite, obovate to narrowly elliptic on lower stem, becoming lanceolate above, obtuse to acute, sessile, 9-40 mm long, 1.5$10 \mathrm{~mm}$ wide, hirsute; margins flat or undulate, with small callus-teeth, serrate to lobed. Flowers solitary or 2-4 per stem; pedicels 9-33 cm long, sparsely hirsute or \pm glabrous; bracteoles lanceolate, 6-13 mm long, hirsute. Hypanthium hemispherical to shortly obconic, 3-6 mm long, hirsute. Sepals 5, erect or spreading, triangular or narrowly triangular, 4-7.5 mm long, hirsute. Corolla shortly campanulate, bluish green but dark blue in the centre and often with black spots, densely hirsute inside tube, otherwise \pm glabrous; tube $2-3 \mathrm{~mm}$ long, shorter than the sepals; lobes 5 , ovate to broadly elliptic, acute or sometimes obtuse, 6-11 mm long, 3-7.5 mm wide. Stamens 5; filaments dark blue, $2.5-4 \mathrm{~mm}$ long, upper half filiform, lower half obtrullate to obtriangular, ciliate, with rounded shoulders; anthers 2-3.5 mm long. Ovary 5-locular. Style dark blue, $4.5-7 \mathrm{~mm}$ long, 5-fid, deeply constricted close to the stigmatic lobes, covered with pollen-presenting hairs above the constriction, without glands; stigmatic lobes 1-1.5 mm long. Capsule hemispherical to shortly obconic, 5-11 mm long, 5-9 mm wide, hirsute. Seeds c. $0.4 \mathrm{~mm}$ long. Figure 23.

FLOWERING PERIOD: September-November.

Distribution: Native to South Africa. Introduced to south-western Australia, where it now occurs from Kalbarri in the north to Tambellup in the south. Figure 33a.

Habitat: Disturbed sites.

Notes: Characteristic features of $W$. capensis are its annual, single- or few-stemmed habit; dense indumentum; sparingly branched stems; strongly toothed leaves; long pedicels; large, shortly campanulate, bluish green, hirsute corollas; dark blue filaments and style; 5-locular ovaries and 5-fid styles; and broad, densely hirsute capsules.

The earliest Australian specimen was collected in 1898 at Perth.

SELECTEd SPECIMENS (31 examined): WESTERN Australia: Irwin: Kalbarri, Corrick 8223, Sep 1982 (MEL, NSW); $5 \mathrm{~km}$ W of Kalbarri, Crisp, Taylor $\mathcal{E}$ Jackson 6304, Oct 1979 (CBG); c. $8 \mathrm{~km} \mathrm{SW} \mathrm{of}$ Lake Indoon, Hnatiuk 770924, Sep 1977 (PERTH). Drummond: Yanchep Natl Park, Scrymgeour 129, Oct 1965 (PERTH); Guildford, Andrews, May-Oct 1901 (PERTH); Perth, Helms, Nov 1898 (NSW 67010). Dale: $300 \mathrm{~m} \mathrm{~S}$ of Edgewater Rd, Canning R., Clark 166, Oct 1974 (PERTH). Menzies: Cape Naturaliste, Canning 6600, Oct 1968 (CBG). Eyre: 1 mile [2 km] E of Tambellup, Newbey 1183, Oct 1963 (PERTH). Avon: Wongan Hills, Clyne, Oct 1969 (NSW). 


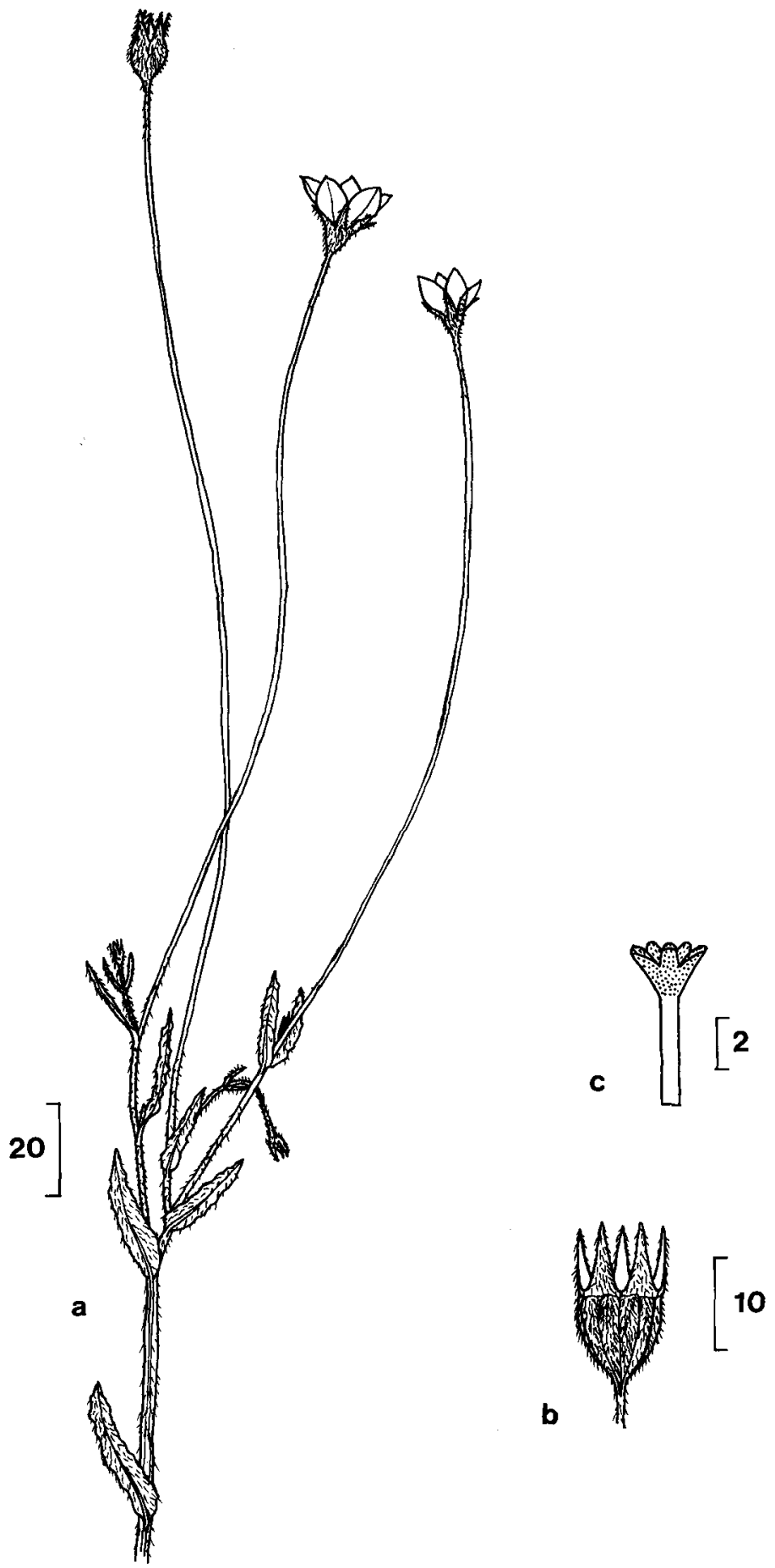

Figure 23. W. capensis: a, habit; b, capsule; c, style. From Corrick 8223. Scale bars in $\mathrm{mm}$. 


\section{Unplaced names}

Wahlenbergia gracilis var. alba Guilfoyle (1909: 365), nom. nud.

W. gracilis var. polymorpha de Candolle (1830: 142). W. marginata var. polymorpha (A. DC.) Hochreutiner (1934: 290). TYPE: 'Campanula polymorpha diffusa Soland. Herb. Banks.'

W. gracilis var. pygmaea Wawra (1883: 133). TYPE: 'Victoria; Wiessengründe im Murraygebiet. Coll. I. 487.'

W. vinciflora var. rosulata Black (1934: 183). TYPE: 'Gladstone; Quorn.'

\section{Acknowledgements}

This paper is based chiefly on my Ph.D. study at the Botany Department, University of Sydney, in the 1970s. My special thanks go to my supervisor, Roger Carolin, for his assistance during the study and for sharing the information and insights gained during his own, largely unpublished study of the genus in the 1950s and 1960s. I am grateful to the Director and staff of the National Herbarium of N.S.W. for providing facilities and assistance to allow me to continue my study of the genus on a part-time basis during the 1980s. I am also grateful to the Directors of the following herbaria for forwarding specimens on loan: AD, ADW, BRI, CANB, CBG, DNA, HO, MEL, NT and PERTH. Judith Petterson kindly provided information from her unpublished study of the genus in New Zealand. Barbara Briggs, Lawrie Johnson, Joy Thompson, Karen Wilson and Peter Wilson made helpful comments on the manuscript. Lola Smith drew the species illustrations and plotted the distribution maps.

\section{References}

Allan, H.H. (1961) Flora of New Zealand, vol. 1 (Government Printer: Wellington).

Andrews, H.C. (1802) The Botanist's Repository, vol. 4.

Bailey, F.M. (1900) The Queensland Flora, vol. 3 (Diddams: Brisbane).

Barlow, B.A. (1986) A revised natural region map for Australia. Brunonia 8: 387-392.

Beadle, N.C.W. (1984) Students Flora of North Eastern New South Wales, part 5 (University of New England: Armidale).

Beadle, N.C.W., Evans, O.D. \& Carolin, R.C. (1982) Flora of the Sydney Region, edn 3 (Reed: Sydney).

Bentham, G. (1837) Campanulaceae. In S.L. Endlicher, E. Fenzl, G. Bentham \& H.W. Schott, Enumeratio Plantarum quos in Novae Hollandiae ... Collegit Carolus Liber Baro de Hügel.

Bentham, G. (1869) Flora Australiensis, vol. 4.

Black, J.M. (1934) Additions to the flora of South Australia No. 32. Trans. E Proc. Roy Soc. South Australia 58: 168-186.

Black, J.M. \& Robertson, E.L. (1957) Flora of South Australia, edn 2, part 4 (Government Printer: Adelaide).

Borgmann, E. (1964) Anteil der Polyploiden in der Flora des Bismarckgebirges von Ostneuguinea. Z. Bot. 52: 118-172.

Brehmer, W. von (1915a) Ueber die systematische Gliederung und Entwicklung der Gattung Wahlenbergia in Afrika. Bot. Jahrb. Syst. 53: 9-71.

Brehmer, W. von (1915b) Aufzählung der afrikanischen Arten von Wahlenbergia nebst Diagnosen der neuen Arten. Bot. Jahrb. Syst. 53: 72-143.

Briggs, B.G. \& Johnson, L.A.S. (1979) Evolution in the Myrtaceae - evidence from inflorescence structure. Proc. Linn. Soc. New South Wales 102: 157-256. 
Briggs, J.D. \& Leigh, J.H. (1988) Rare or Threatened Australian Plants. Australian National Parks \& Wildlife Service Special Publication No. 14.

Britten, J. (1901) Illustrations of the Botany of Captain Cook's Voyage Round the World, vol. 2 (British Museum: London).

Brown, N.E. (1913) Revision of Wahlenbergia species whose range is limited to Australia and New Zealand. Gard. Chron. 54: 316-317, 336-337, 354-355.

Brown, R. (1810) Prodromus Florae Novae Hollandiae et Insulae Van-Diemen.

Burbidge, N.T. \& Gray, M. (1970) Flora of the Australian Capital Territory (Australian National University Press: Canberra).

Candolle, A.L.P.P. de (1830) Monographie des Campanulées.

Candolle, A.L.P.P. de (1839) Campanulaceae. In A.P. de Candolle (ed.), Prodromus Systematis Naturalis Regni Vegetabilis, part 7: 414-496.

Carolin, R.C. (1960) The structures involved in the presentation of pollen to visiting insects in the order Campanulales. Proc. Linn. Soc. New South Wales 85: 197-207.

Carolin, R.C. (1964) Taxonomic and nomenclatural notes on the genus Wahlenbergia in Australia. Proc. Linn. Soc. New South Wales 89: 235-240.

Carolin, R.C. (1967) The concept of the inflorescence in the order Campanulales. Proc. Linn. Soc. New South Wales 92: 7-26.

Carolin, R.C. (1981) Campanulaceae. Pp. 349-351 in J. Jessop (ed.), Flora of Central Australia (Reed: Sydney).

Commelin, K. (1701) Horti Medici Amstelodamensis, part 2.

Costin, A.B., Gray, M., Totterdell, C.J. \& Wimbush, D.J. (1979) Kosciusko Alpine Flora (Collins: Sydney).

Cunningham, G.M., Mulham, W.E., Milthorpe, P.L. \& Leigh, J.H. (1981) Plants of Western New South Wales (Government Printer: Sydney).

Curtis, W.M. (1963) The Student's Flora of Tasmania, part 2 (Government Printer: Hobart).

Curtis, W.M. \& Stones, M. (1969). The Endemic Flora of Tasmania, part 2 (Ariel Press: London).

Darlington, C.D. \& Wylie, A.P. (1955) Chromosome Atlas of Flowering Plants (Allen \& Unwin: London).

Decaisne, J. (1849) Revue Horticole, ser. 3, 3: 41.

Delile, A.R. (1813) Flore d'Egypte.

Dietrich, D.N.F. (1839) Synopsis Plantarum, vol. 1.

Domin, K. (1929) Beiträge zur Flora und Pflanzengeographie Australiens (Campanulaceae). Bibl. Bot. 89: 638-639.

Eichler, Hj. (1963) Some new names and new combinations relevant to the Australian flora. Taxon 12: 295-297.

Ewart, A.J. (1930) Flora of Victoria (Melbourne University Press: Melbourne).

Forster, G. (1786) Florulae Insularum Australium Prodromus.

Gadella, T.W.J. (1966) Some notes on the delimitation of genera in the Campanulaceae. Proc. Kon. Nederl. Akad. Wetensch. C, 69: 502-521.

Grieve, B.J. \& Blackall, W.E. (1982) How to Know Western Australian Wildflowers, edn 2, part 4 (University of W.A. Press: Perth).

Guilfoyle, W.R. (1909) Australian Plants Suitable for Gardens, Parks, Timber Reserves, etc. (Whitcombe \& Tombs: Melbourne).

Hochreutiner, B.-P.-G. (1934) Plantae Hochreutineranae. Candollea 5: 175-341.

Hooker, J.D. (1847) Florae Tasmaniae spicilegium. London J. Bot. 6: 265-286.

Hooker, J.D. (1852) Botany of the Antarctic Voyage, Part II, Flora Novae-Zelandiae, vol. 1.

Hooker, J.D. (1856) Botany of the Antarctic Voyage, Part III, Flora Tasmaniae, vol. 1.

Hooker, J.D. (1864) Handbook of the New Zealand Flora.

Hooker, J.D. (1881) Flora of British India, vol. 3.

Hsu, C.-C. (1967) Preliminary chromosome studies on the vascular plants of Taiwan, 1. Taiwania 13: $117-130$.

Hsu, C.-C. (1968) Preliminary chromosome studies on the vascular plants of Taiwan, 2. Taiwania 14: $11-27$.

I.C.B.N. (1988) International Code of Botanical Nomenclature (eds W. Greuter et al.), Regnum Vegetabile, vol. 118.

Jacobs, S.W.L. \& Pickard, J. (1981) Plants of New South Wales (Government Printer: Sydney).

Kuntze, O. (1891) Revisio Generum Plantarum, vol. 2. 
Labillardière, J.J.H. de (1805) Novae Hollandiae Plantarum Specimen, vol. 1.

L'Héritier de Brutelle, C.-L. (1789) Sertum Anglicum.

Linnaeus, C. (1753) Species Plantarum.

Loddiges, C. (1828) The Botanical Cabinet, part 15.

Lothian, N. (1947a) Critical notes on the genus Wahlenbergia Schrader; with descriptions of new species in the Australian region. Proc. Linn. Soc. New South Wales 71: 201-235.

Lothian, N. (1947b) Wahlenbergia limenophylax, an unintentional orthographic error. Proc. Linn. Soc. New South Wales 72: 366.

Lothian, N. (1947c) Remarks on Victorian bluebells (Wahlenbergia). Victorian Nat. 63: 229-235.

Lothian, N. (1956) Alpine bluebells: some further comments and descriptions of two new species of Wahlenbergia. Victorian Nat. 72: 165-169.

Moore, C. \& Betche, E. (1893) Handbook of the Flora of New South Wales.

Pickard, J. (1983) Rare or threatened vascular plants of Lord Howe Island. Biol. Conserv. 27: 125139.

Pressey, R.L., Cohn, J.S. \& Porter, J.L. (1990) Vascular plants with restricted distributions in the Western Division of New South Wales. Proc. Linn. Soc. New South Wales 112: 213-227.

Rodd, A.N. \& Pickard, J. (1983) Census of vascular flora of Lord Howe Island. Cunninghamia 1: $267-280$.

Rodway, L. (1903) The Tasmanian Flora (Government Printer: Hobart).

Roth, A.W. (1821) Novae Plantarum Species praesertim Indiae Orientalis.

Schrader, H.A. (1814) Plantarum Semina in Horto Academico Gottingensi Anno 1814 Collecta.

Schrader, H.A. (1827) Blumenbachia, Novum e Loasearum Familia Genus.

Siebert, A. \& Voss, A. (1896) Vilmorin's Blumengärtneri, vol. 1.

Smith, J.E. (1805) Exotic Botany.

Smith, P.J. (1976) Evolution of the genus Wahlenbergia in Australia. Unpublished Ph.D. thesis, University of Sydney.

Smith, P.J. (1986) Wahlenbergia. In J.P. Jessop \& H.R. Toelken (eds), Flora of South Australia, part 3: 1376-1383.

Smith, P.J. (1989) Wahlenbergia caryophylloides (Campanulaceae), a new species from northern Australia. Nuytsia 7: 63-67.

Smith, P.J. (in press) Campanulaceae. In G.J. Harden (ed.), Flora of New South Wales, vol. 3 (N.S.W. University Press: Sydney).

Stanley, T.D. \& Ross, E.M. (1986) Flora of South-eastern Queensland, vol. 2 (Government Printer: Brisbane).

Stearn, W.T. (1951) Nomenclature notes. Gard. Chron. 130: 169.

Steenis, C.G.G.J. van (1960) Original generic description and typification of the genus 8668 Wahlenbergia Schrad. ex Roth (1821) (Campanulaceae). Taxon 9: 122.

Sugiura, T. (1942) Studies on the chromosome numbers in Campanulaceae, I, Campanuloideae - Campanuleae. Cytologia 12: 418-434.

Swartz, O. (1788) Nova Genera et Species Plantarum seu Prodromus Descriptionum Vegetabilium Maximam Partem Incognitorum quae sub Itinere in Indiam Occidentalem Annis 1783-87 Digessit.

Sweet, R. (1830) Hortus Britannicus, edn 2.

Thulin, M. (1975) The genus Wahlenbergia s.lat. (Campanulaceae) in tropical Africa and Madagascar. Symb. Bot. Upsal. 21 (1).

Thulin, M. (1987) New species of Wahlenbergia (Campanulaceae) from Africa. Nordic J. Bot. 7: 261265.

Troll, W. (1964) Die Infloreszenzen. Typologie und Stellung im Aufbau des Vegetationskörpers, 1. I Deskriptive Morphologie der Infloreszenzen; II Typologie der Infloreszenzen (Jena: Gustav Fischer).

Troll, W. (1969) Die Infloreszenzen. Typologie und Stellung im Aufbau des Vegetationskörpers, 2. III Monotele Synfloreszenzen (Jena: Gustav Fischer).

Tuyn, P. (1960) Wahlenbergia. In C.G.G.J. van Steenis (ed.), Flora Malesiana, ser. 1, vol. 6: 111-118.

Ventenat, E.P. (1803) Jardin de la Malmaison, vol. 1.

Vriese, W.H. de (1848) Campanulaceae. In J.G.C. Lehmann (ed.), Plantae Preissianae, vol. 2.

Want, G. (1963) Sporogenesis, gametogenesis, and embryogeny of Wahlenbergia bicolor N. Lothian. Aust. J. Bot. 11: 152-167.

Wawra von Fernsee, H. (1883) Itinera Principum Saxe-Coburgi, vol. 1.

Webb, C.J., Sykes, W.R. \& Garnock-Jones, P.J. (1988) Flora of New Zealand, vol. 4 (Botany Division, DSIR: Christchurch). 
Wheeler, J.R. (1987) Campanulaceae. In N.G. Marchant, J.R. Wheeler, B.L. Rye, E.M. Bennett, N.S. Lander \& T.D. MacFarlane, Flora of the Perth Region, part 2: 598-600 (Government Printer: Perth).

Wheeler, J.R. \& Smith, P.J. (in press) Campanulaceae. In J.R. Wheeler (ed.), Flora of the Kimberley Region (Government Printer: Perth).

Willdenow, C.L. (1814) Enumeratio Plantarum Horti Regii Botanici Berolinensis, suppl.

Willis, J.H. (1972) A Handbook to Plants in Victoria, vol. 2 (Melbourne University Press: Melbourne).

Manuscript received 24 December 1991

Manuscript accepted 4 May 1992 

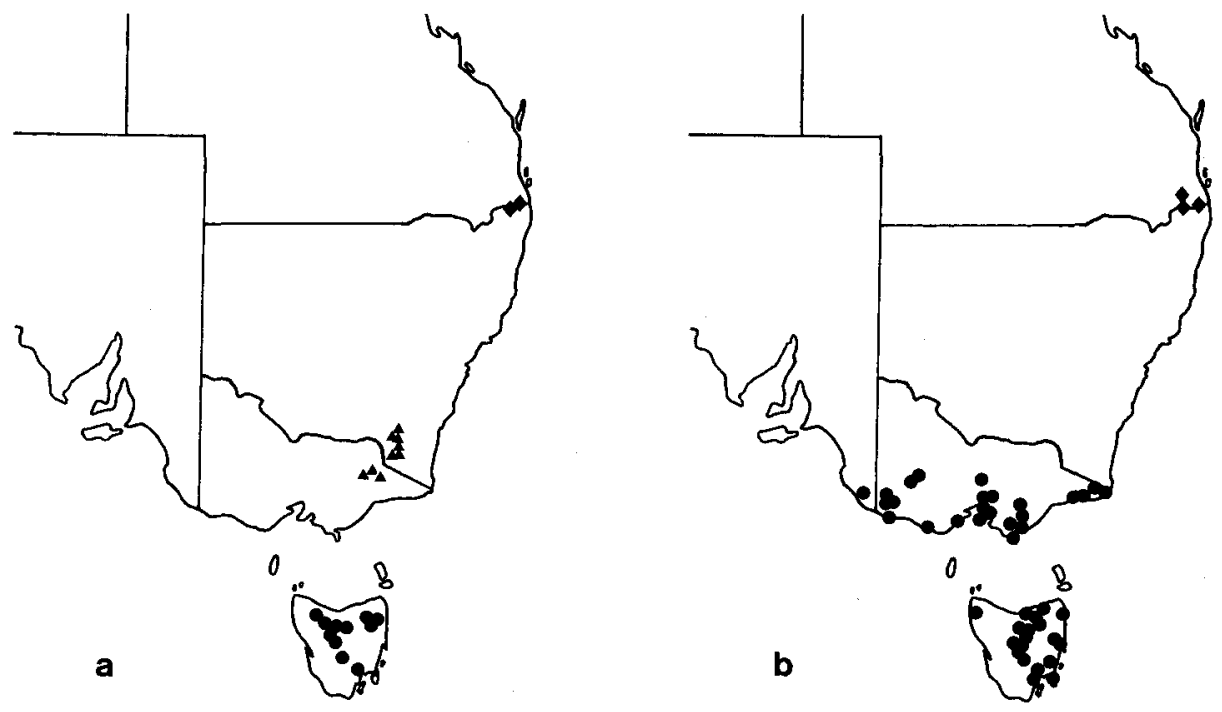

Figure 24. Distribution of: a, W. scopulicola $(\bullet), W$. densifolia $(\boldsymbol{\Lambda})$ and W. saxicola $(\bullet) ; \mathbf{b}$, W. glabra $(\bullet)$ and W. gymnoclada $(\bullet)$.
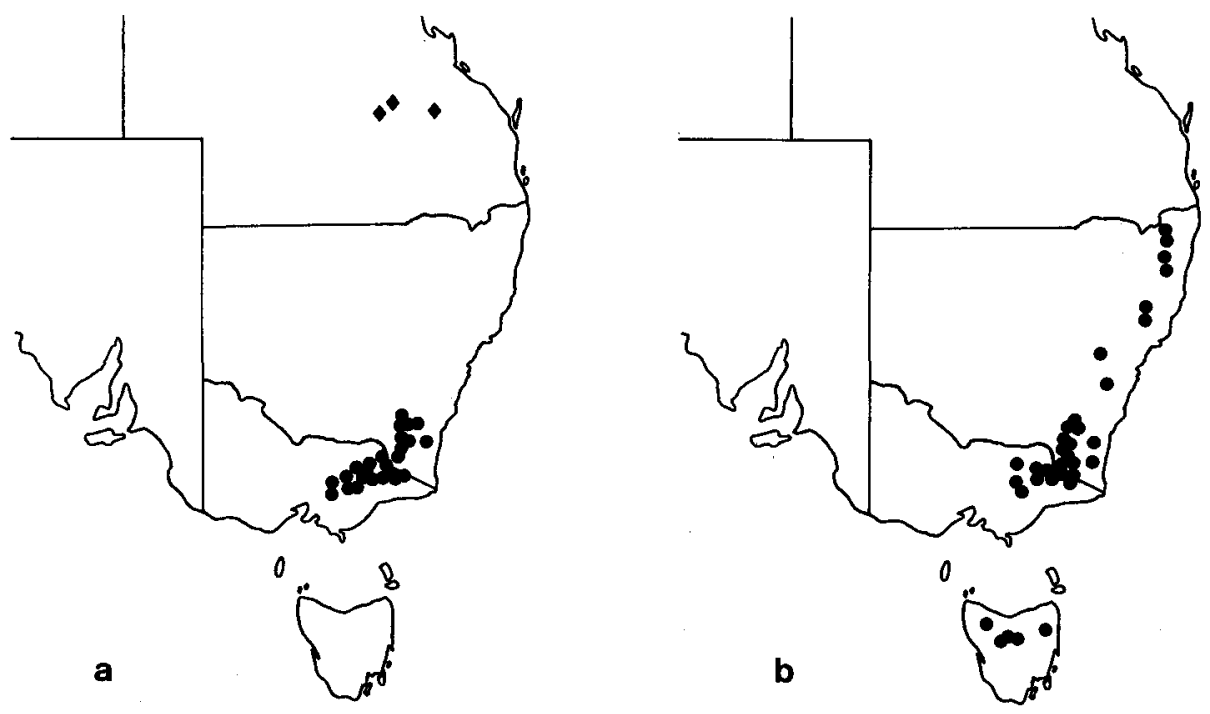

Figure 25. Distribution of: a, W. islensis $(\bullet)$ and $W$. gloriosa $(\bullet)$; b, W. ceracea. 


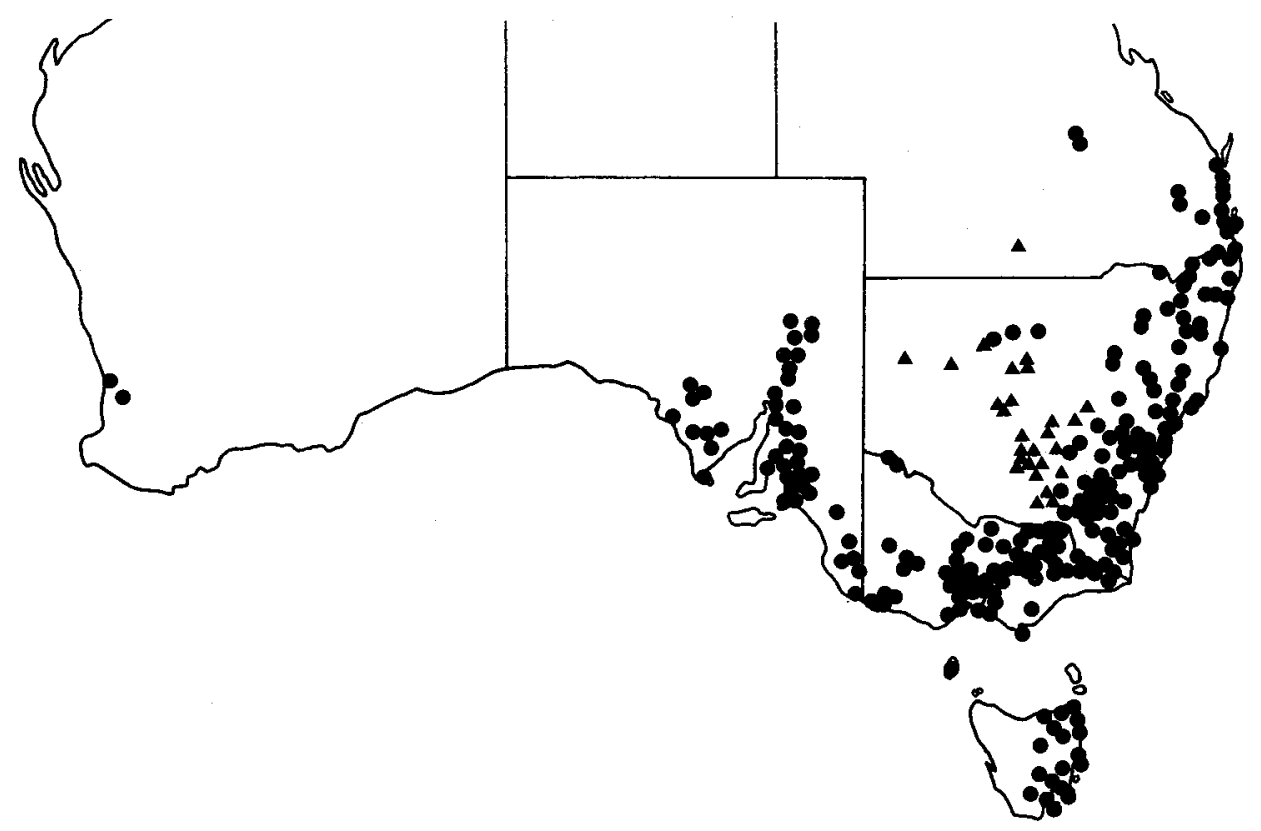

Figure 26. Distribution of W. stricta subsp. stricta (•) and subsp. alterna (ム).
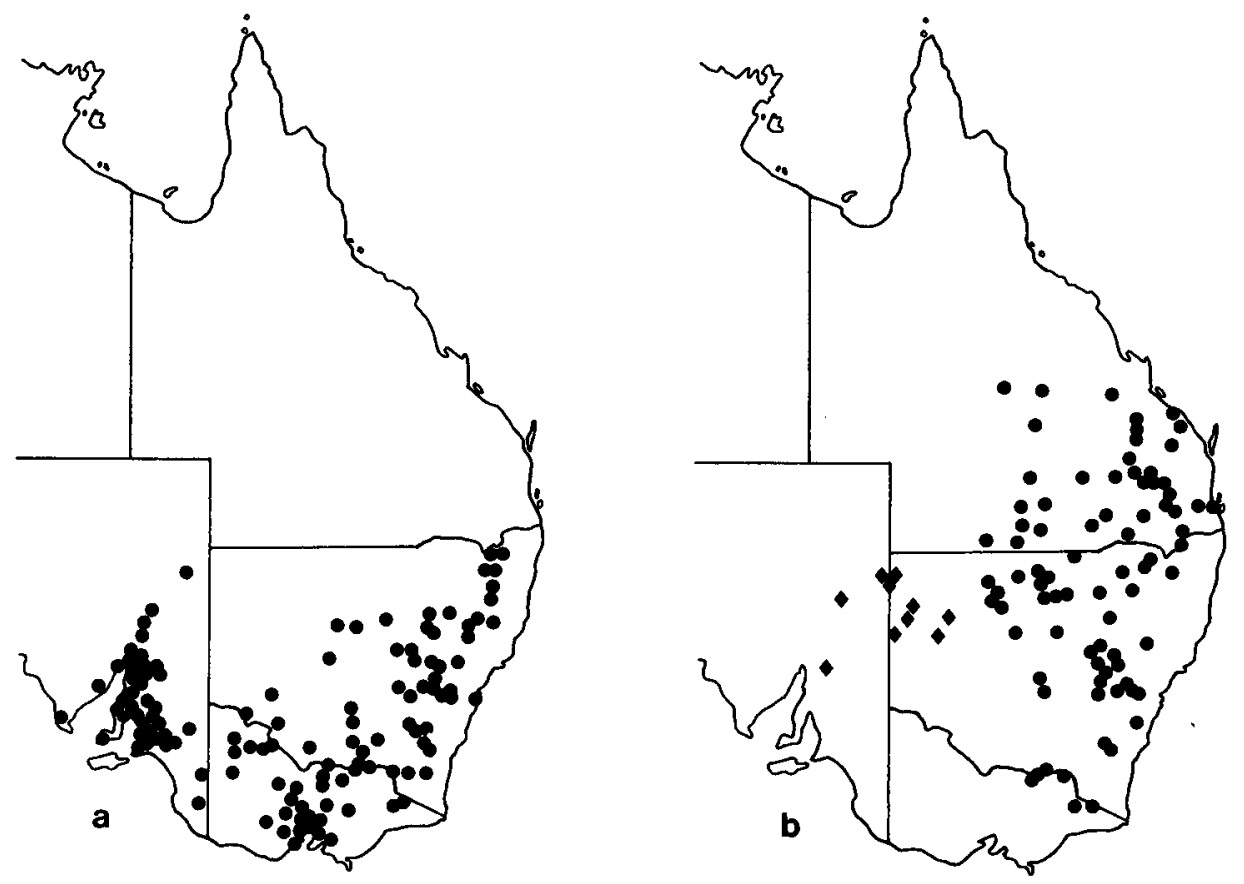

Figure 27. Distribution of: $\mathbf{a}, W$. luteola; $\mathbf{b}, W$. graniticola $(\bullet)$ and W. aridicola $(\bullet)$. 


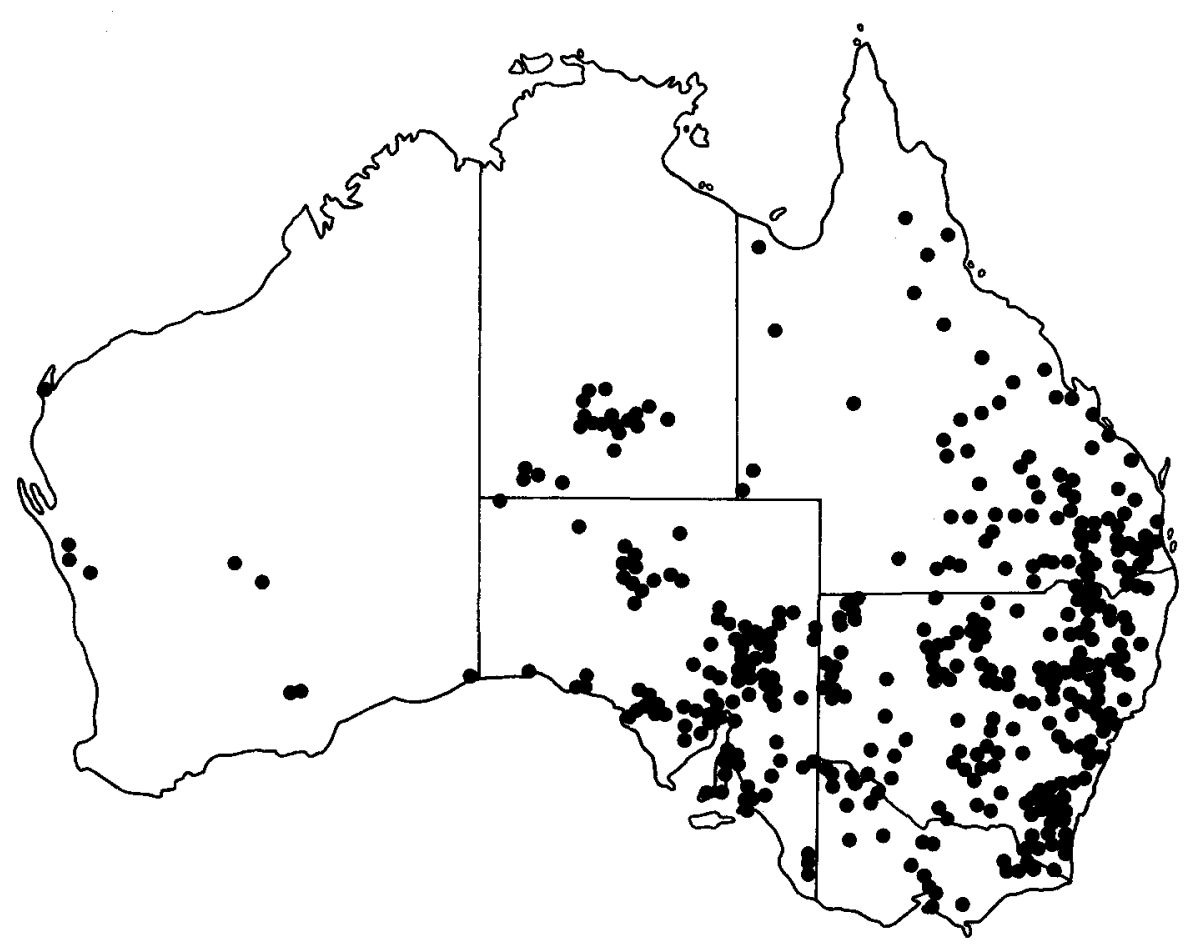

Figure 28. Distribution of W. communis.

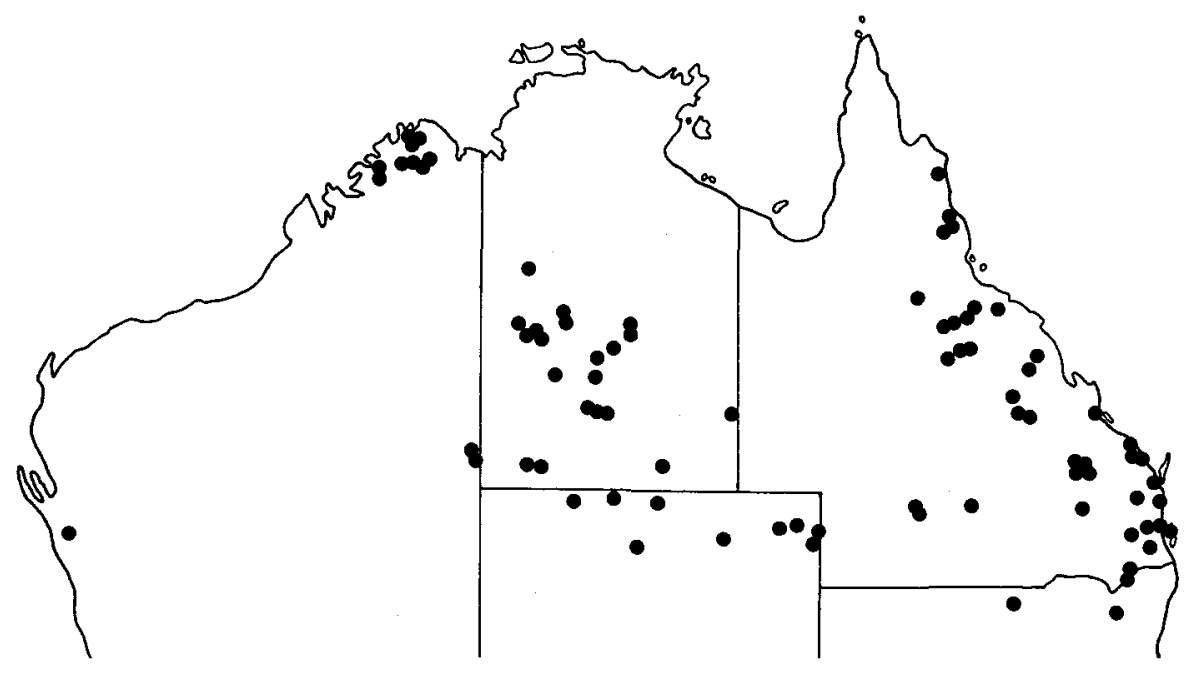

Figure 29. Distribution of $W$. queenslandica. 


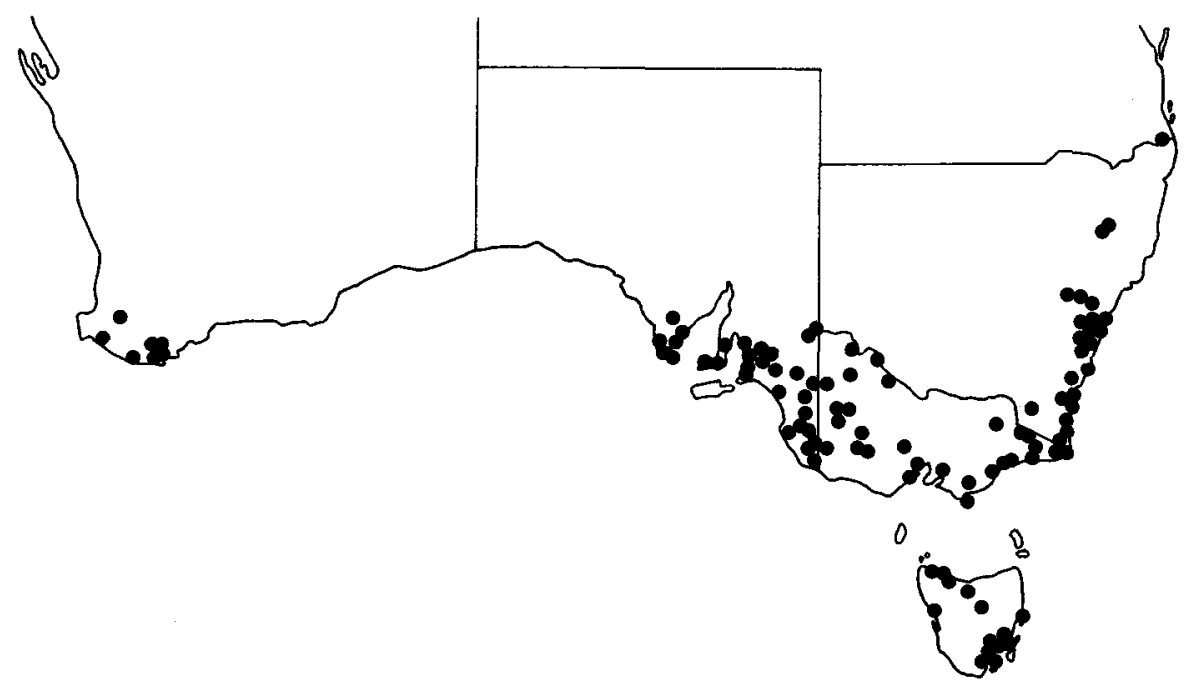

Figure 30. Distribution of W. littoricola.
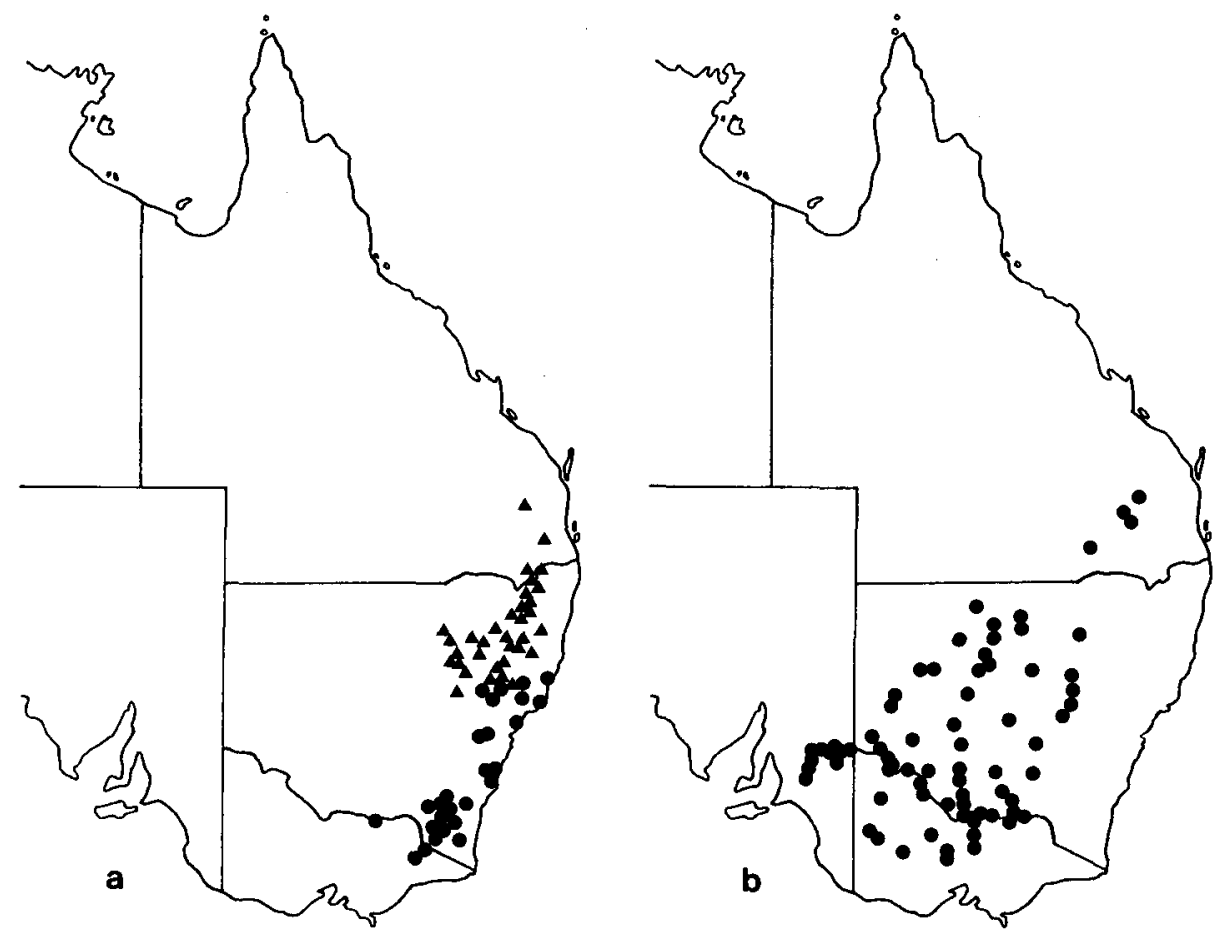

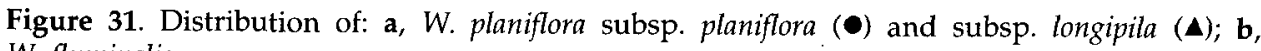
W. fluminalis. 


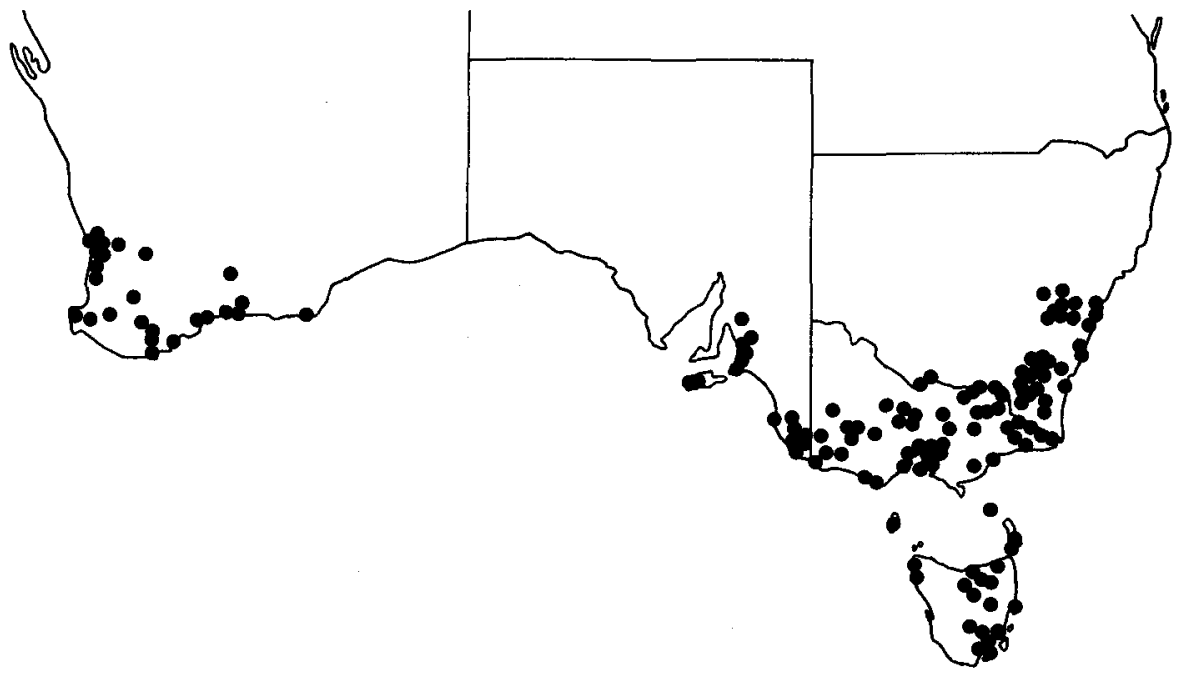

Figure 32. Distribution of W. multicaulis.
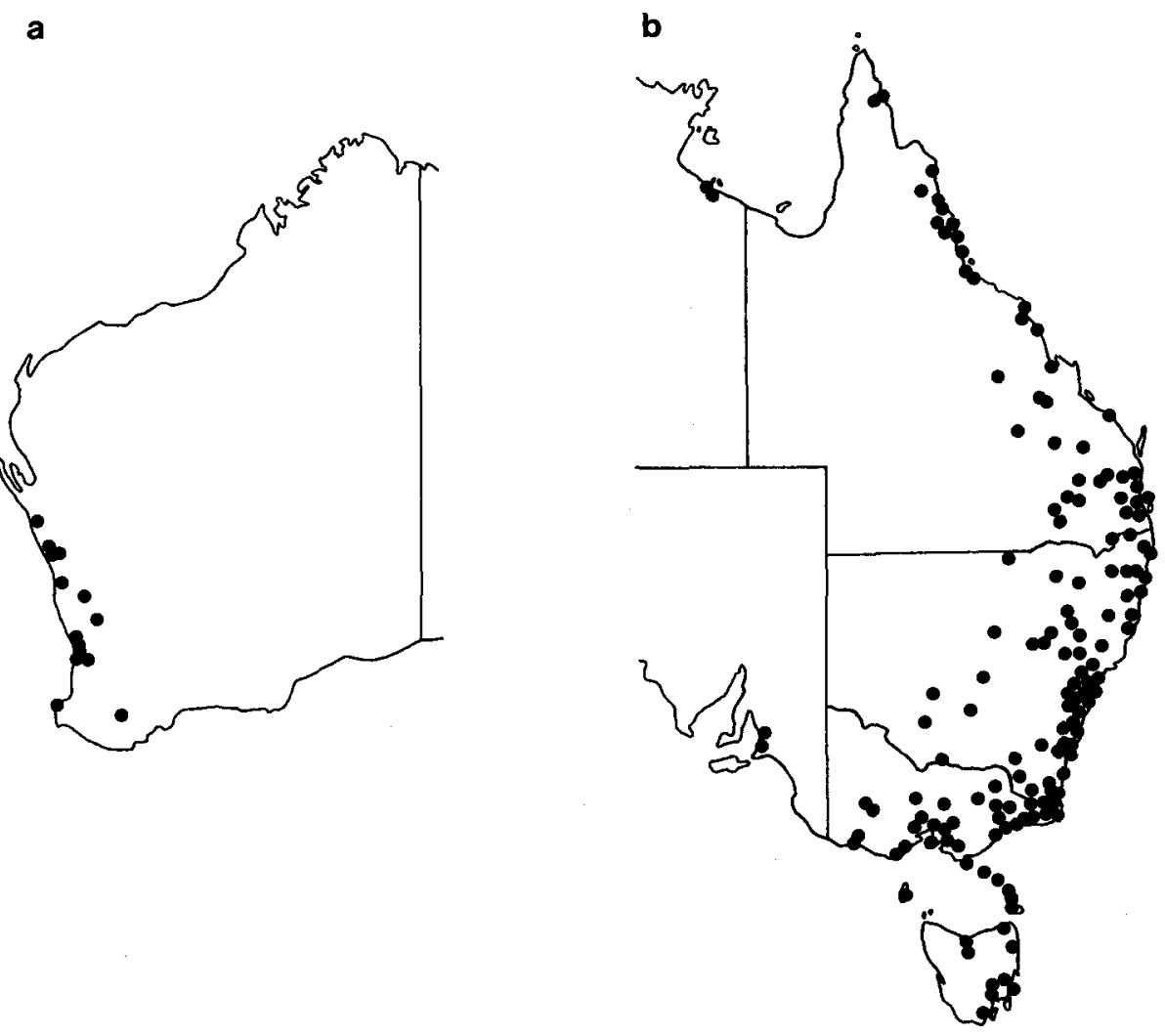

Figure 33. Distribution of a, W. capensis; $\mathbf{b}$, W. gracilis. 


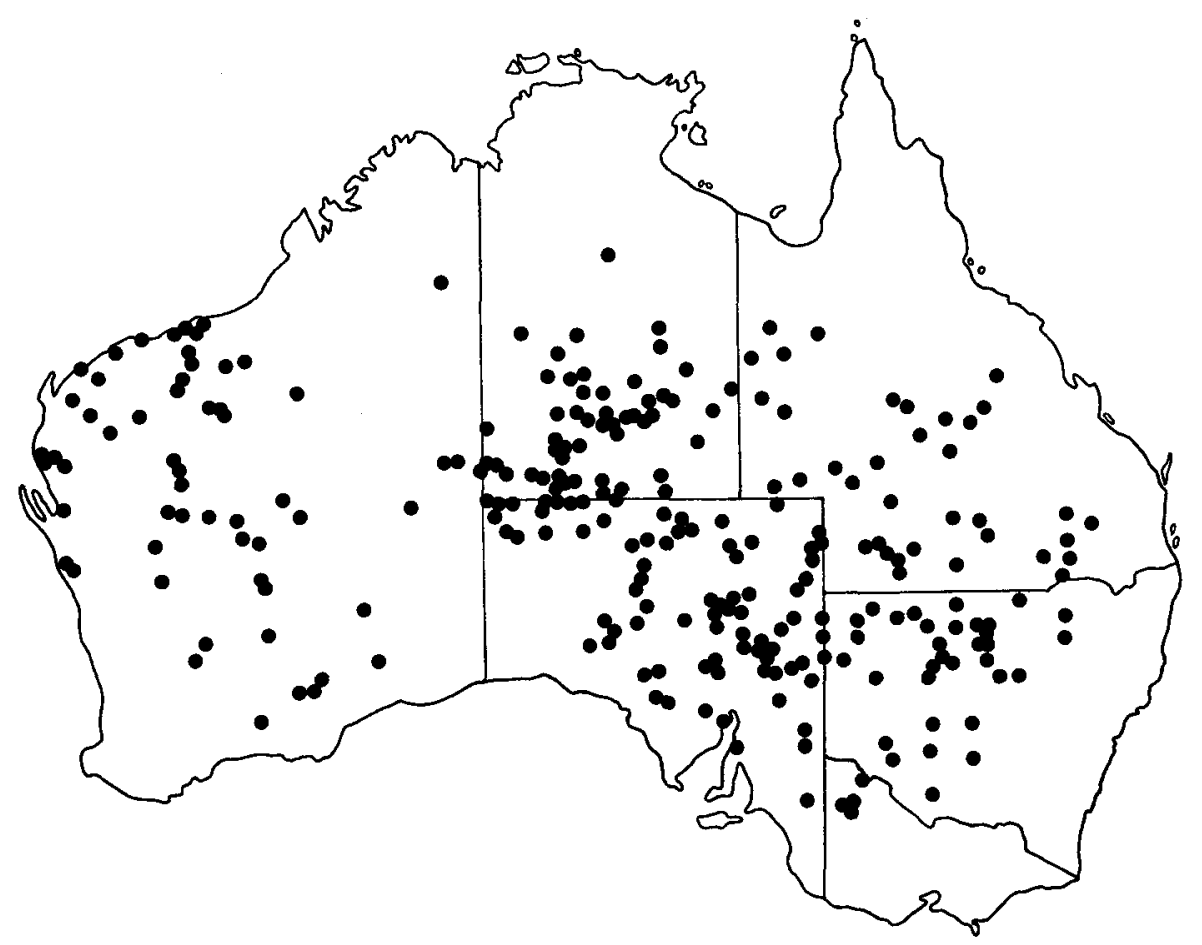

Figure 34. Distribution of W. tumidifructa.

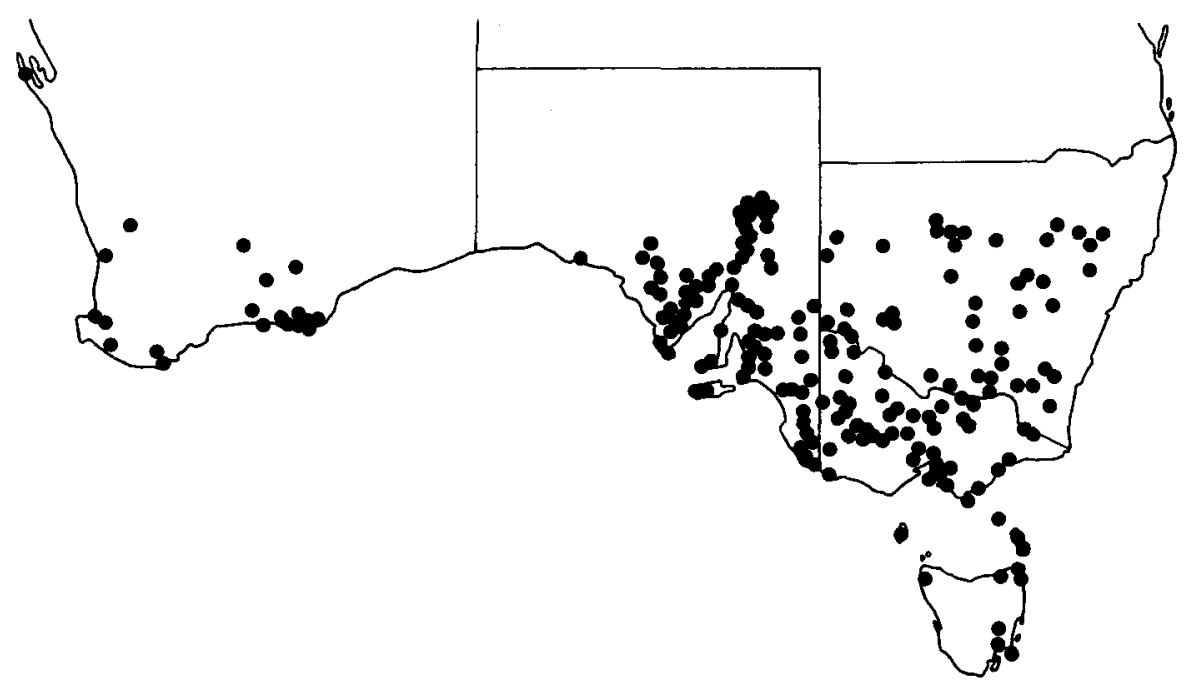

Figure 35. Distribution of W. gracilenta. 


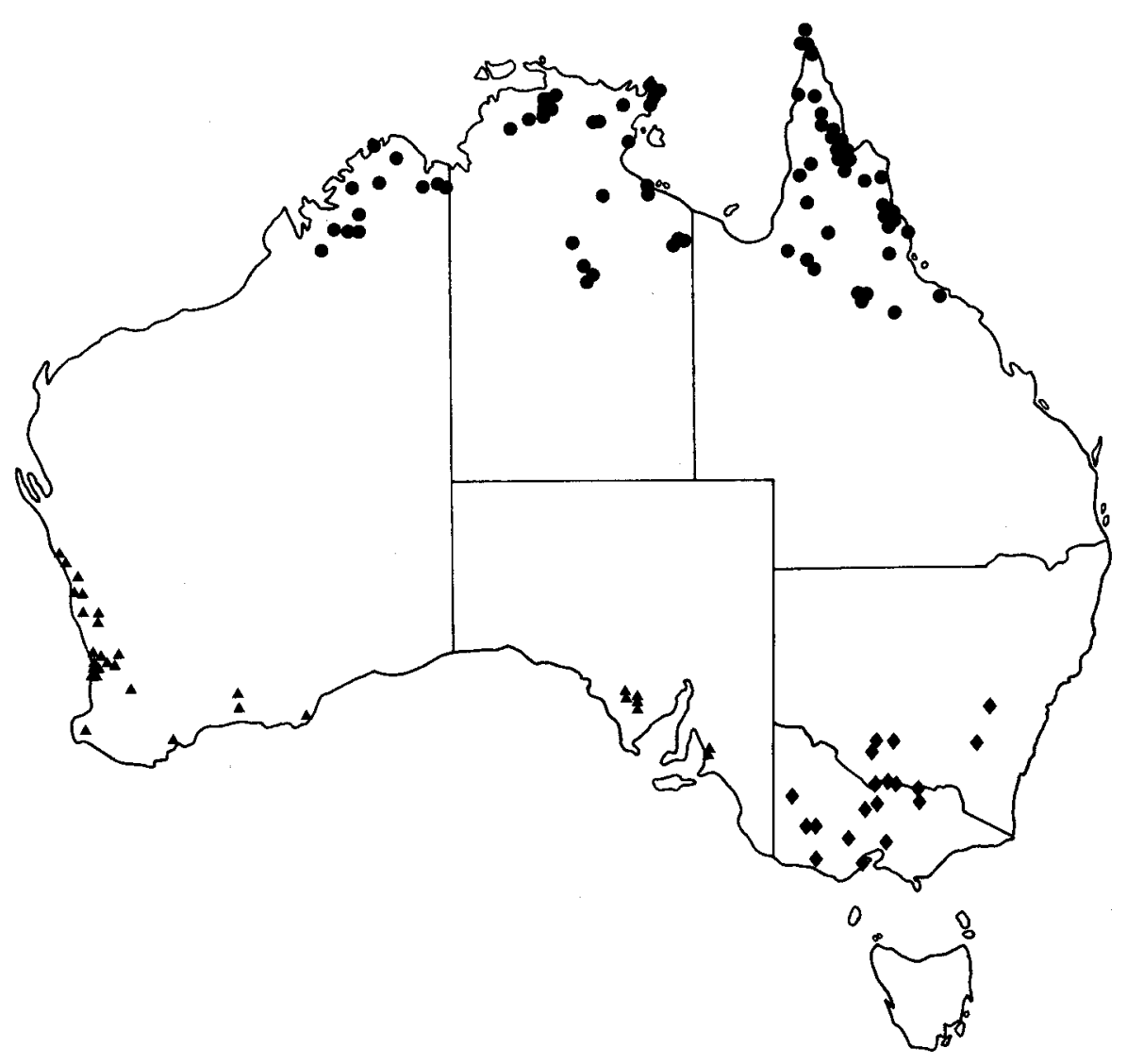

Figure 36. Distribution of W. preissii $(\mathbf{\Lambda}), W$. victoriensis $(\bullet)$ and $W$. caryophylloides $(\bullet)$. 


\section{Index}

New names are printed in boldface, synonyms and illegitimate names are printed in italics.

Campanopsis 107

C. saxicola 123

Campanula

sect. Campanopsis 92, 107

C. capensis 161

C. capillaris 132

C. elongata 161

C. erecta 126

C. gracilis 149

var. capillaris 132

var. littoralis 121

var. stricta 126, 130

var. vinciflora 150

f. stricta 126

C. littoralis 121

C. quadrifida 149

C. saxicola 123

C. sieberi 149

C. vinciflora 126,150

Cephalostigma 91, 107

C. fluminale 91, 146

C. perrottetii 107

Cervicina 91, 107

C. campanuloides 107

C. gracilis 149

Codonopsis 105

Lightfootia 91, 107

L. oxycoccoides 107

L. parvifolia 107

Lobelia dubia 147

Roella decurrens 161

Streleskia montana
Wahlenbergia 107

sect. Aikinia 105

sect. Lobelioides 106

W. albomarginata 106

W. aridicola 139

W. bicolor 126, 130

W. billardierei 121

W. brockiei 106

W. campanuloides 107

W. capensis 107, 161

W. cartilaginea 106

W. caryophylloides 160

W. ceracea 116

W. communis 132

W. congesta 106

W. consimilis 126

W. densifolia 120

W. dioica 150

W. elongata 107,161

W. eurycarpa 150

W. fluminalis 146

W. glabra 113

W. gloriosa 117

W. gracilenta 154

W. gracilis 149

var. alba 163

var. capillaris 132

var. littoralis 121

var. minutiflora 150

var. polymorpha 163

var. pygmaea 163

var. stricta 126 
W. gracilis (cont'd) var. vinciflora 150

f. littoralis 121

f. multicaulis 147

W. graniticola 136

W. gymnoclada 121

W. insulae-howei 124

W. islensis 114

W. limenophylax 124

W. littoralis 121

W. littoricola 140

W. lobelioides 106

W. luteola 130

W. marginata 92 var. grandiflora 117,127 subvar. trichogyna 126

var. littoralis 121

var. neo-caledonica 150

var. polymorpha 163

W. matthewsii 106

W. multicaulis 147

var. dispar 132

W. papuana 106

W. perrottetii 107

W. planiflora 142 subsp. longipila 144

subsp. planiflora 143

W. preissii 157

W. pygmaea 106

W. quadrifida 149

$\mathrm{W}$. queenslandica 135

W. saxicola 123

W. scopulicola 111

W. sieberi 149

W. simplicicaulis 147

W. simpsonii 106
W. stricta 125 subsp. alterna 128 subsp. stricta 126

W. tadgellii 147

W. trichogyna 126

W. tumidifructa 153

W. undulata 106

W. vinciflora 126,150

var. littoralis 121

var. rosulata 163

f. eriocalyx 126

W. victoriensis 158

W. virgata 106 